Copyright

by

Li Yong 2005 
The Dissertation Committee for Li Yong certifies that this is the approved version of the following dissertation:

\section{INTERNAL CAPITAL ALLOCATION AND EXECUTIVE COMPENSATION}

\section{Committee:}

Laura Starks, Supervisor

Andres Almazan

Jay Hartzell

Jennifer Huang

Yanfeng Xue 


\title{
INTERNAL CAPITAL ALLOCATION AND EXECUTIVE COMPENSATION
}

\author{
by \\ Li Yong, B.A. \\ Dissertation \\ Presented to the Faculty of the Graduate School of \\ the University of Texas at Austin \\ in Partial Fulfillment \\ of the Requirements \\ for the Degree of \\ Doctor of Philosophy
}

The University of Texas at Austin

August 2005 


\section{Dedication}

To Mom, Dad, and Jin 


\section{Acknowledgements}

I would like to express my appreciation to all of the members of my dissertation committee. I am indebted to Jennifer Huang for her insights and guidance in the development of this project. Helpful comments and advice from Andres Almazan, Jay Hartzell, and Yanfeng Xue, have made this dissertation more complete. I especially thank my dissertation chair, Laura Starks, for her invaluable mentorship and support throughout my graduate education.

Finally, I thank my parents and my sister, Lu, for setting me on the path, and my husband, Jin, for his encouragement and support throughout the years. 


\title{
INTERNAL CAPITAL ALLOCATION AND EXECUTIVE COMPENSATION
}

\author{
Publication No. \\ Li Yong, Ph.D. \\ The University of Texas at Austin, 2005 \\ Supervisor: Laura T. Starks
}

This research examines the connection between executive compensation and within-firm capital allocation decisions by multi-segment firms. Although previous studies have considered the asymmetric information between a firm's headquarter and its divisions, they have not explicitly addressed the issue of how internal capital allocation decisions are affected by the CEO's own incentives. In this study, I focus on incentives that derive from the CEO's compensation.

First, I show that a conglomerate CEO's compensation is related to the weighted average pay in industries associated with the firm's segments. Next, I document that executives of multi-segment firms appear to respond strongly to compensation incentives when allocating funds across segments. Specifically, I find that firms invest more in 
segments associated with higher levels of executive compensation, and that they are more likely to add (drop) segments with higher (lower) pay levels. Importantly, the effects of compensation remain even after controlling for economic factors that have previously been documented to affect firms' investment decisions (e.g., past performance, size, growth opportunity, and industry). Furthermore, I present evidence that following active reallocations, CEO compensation does go up in subsequent years. In particular, firms engaging in segment restructuring activities experience faster growth in $\mathrm{CEO}$ compensation relative to the market. In addition, I find that incentives created by executive stock options lead CEOs to invest more in riskier industries and industries with better past performance. Overall, my results suggest that both the level and structure of executive compensation affect firms' internal capital allocations. This conclusion is robust to various sensitivity checks. 


\section{TABLE OF CONTENTS}

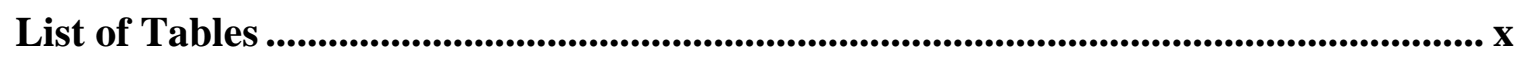

List of Figures........................................................................................................................ xii

Chapter One: Introduction ..................................................................................................... 1

Chapter Two: Literature Review ……................................................................................ 7

2.1 Overview of Internal Capital Markets ………………...................................... 7

2.1.1 Active Internal Capital Markets ....................................................................... 7

2.1.2 Debate on the Efficiency of Internal Capital Markets .................................... 9

2.2 Overview of Executive compensation ............................................................. 13

2.2.1 Practice and Recent Trends in Executive Compensation ............................. 13

2.2.2 Executive Compensation and Firm Risk....................................................... 16

2.3 Managerial Incentives and Internal Capital Markets ........................................... 21

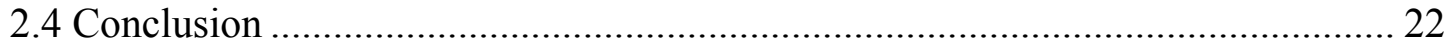

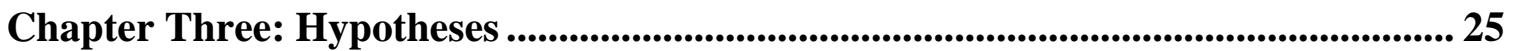

3.1 Multi-segment Firms' CEO compensation and Industry Pay Levels ................... 25

3.2 Segment Investment and the Level of Compensation............................................ 26

3.3 Compensation following Segment Restructurings.............................................. 28

3.4 Segment Investment and Stock Option Incentives ............................................ 28

3.5 Compensation and Firm Investment Risk ……………........................................ 29

Chapter Four: Sample Selection and Descriptive Statistics ............................................. 31

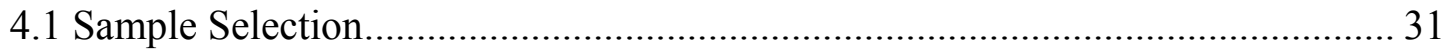

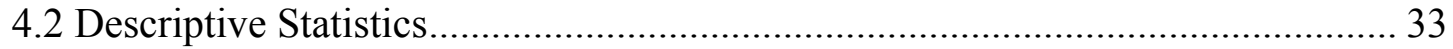

4.3 Industry Pay Rankings ................................................................................ 34

4.4 Investment in Technology Segments .................................................................... 35

Chapter Five: Methodology and Research Design ......................................................... 37

5.1 Synthetic Compensation .............................................................................. 37

5.2 The Model: Explanatory Variables and Estimation Equations.............................. 39

5.2.1 Actual and Synthetic Compensation............................................................. 39

5.2.2 Segment Investment and the Level of Compensation................................... 40

5.2.3 Compensation following Segment Restructurings........................................ 43

5.2.4 Segment Investment and Stock Option Incentives .................................... 43

5.2.5 Compensation and Firm Investment Risk................................................... 44

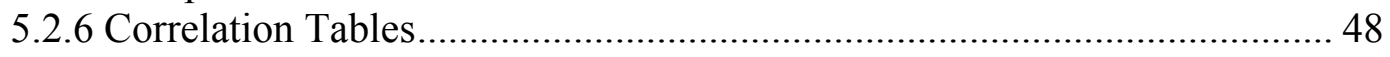

Chapter Six: Results and Discussion.................................................................................... 49

6.1 Actual and Synthetic Ccompensation ............................................................... 49

6.2 Segment Investment and the Level of Compensation......................................... 50

6.3 Compensation following Segment Restructurings............................................... 52 
6.4 Segment Investment and Stock Option Incentives ..................................... 53

6.5 Compensation and Firm Investment Risk ...................................................... 53

Chapter Seven: Robustness Checks ................................................................... 56

7.1 Year Dummies in the Compensation Regression ........................................... 56

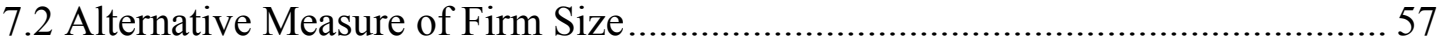

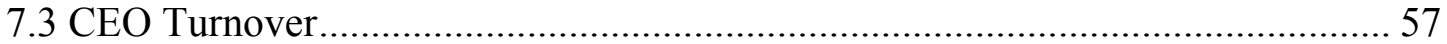

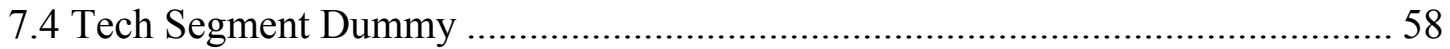

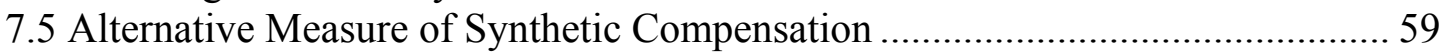

7.6 Alternative Measures of Investment Opportunities .............................................. 59

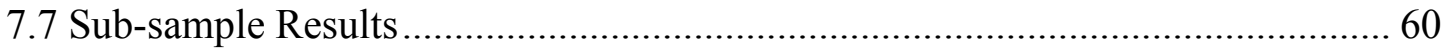

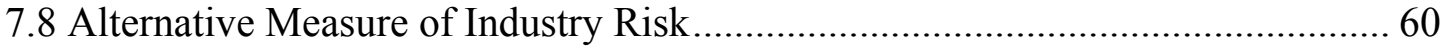

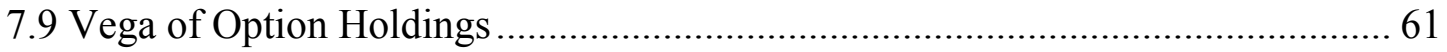

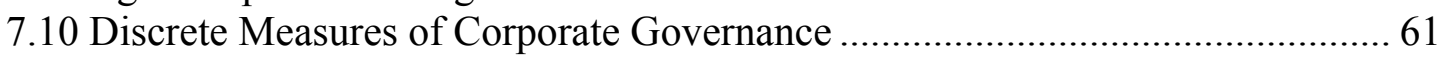

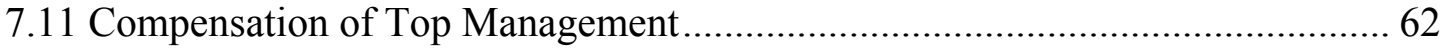

Chapter Eight: Segment Investment and Industry Returns...................................64

Chapter Nine: Conclusion ..............................................................................................67 67

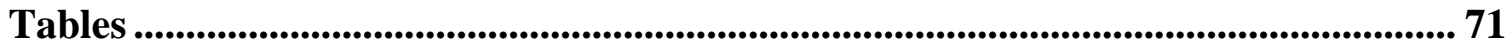

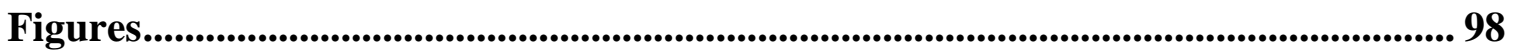

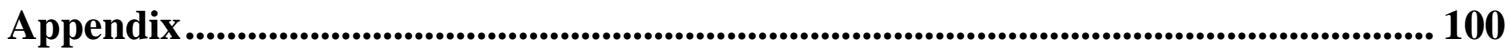

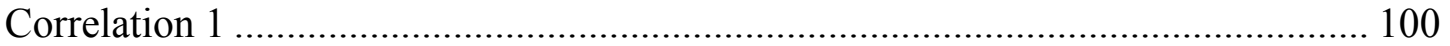

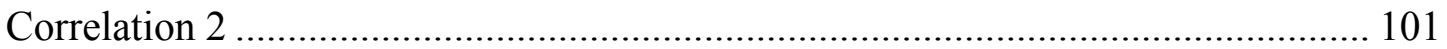

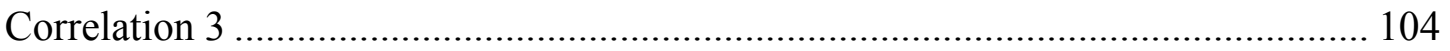

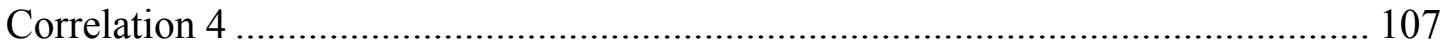

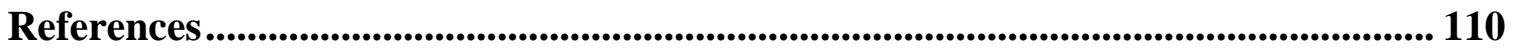

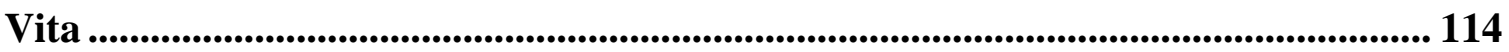




\section{LIST OF TABLES}

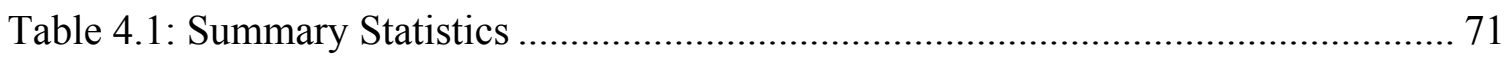

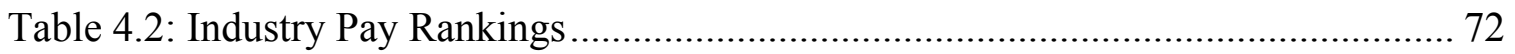

Table 4.3: Investment in Technology Segments........................................................... 77

Table 6.1: Actual and Synthetic Compensation.......................................................... 78

Table 6.2: Segment Investment and the Level of Compensation ................................... 79

Table 6.3: Segment Investment, Industry Risk, and Option Grants ................................ 80

Table 6.4: Firm Investment Risk and Compensation Characteristics............................... 81

Table 7.1: Actual and Synthetic Compensation with Year Dummies .............................. 82

Table 7.2: Actual and Synthetic Compensation-Alternative Measure of Firm Size......... 84

Table 7.3: Segment Investment and the Level of Compensation with CEO Turnover .... 85

Table 7.4: Segment Investment and the Level of Compensation with Tech Dummy ...... 86

Table 7.5: Segment Investment and the Level of Compensation with Alternative Measure

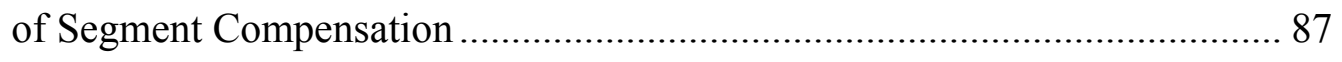

Table 7.6: Segment Investment and the Level of Compensation with Alternative

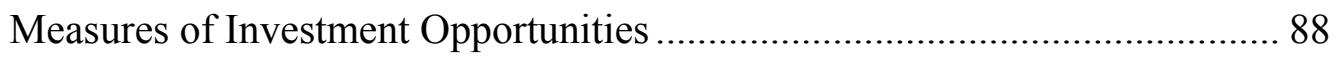

Table 7.7: Segment Investment and the Level of Compensation without Smallest

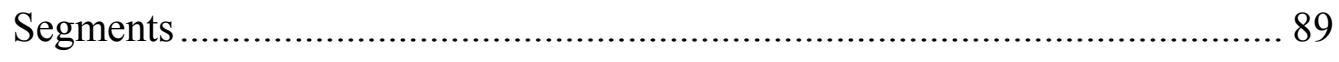

Table 7.8: Segment Investment and the Level of Compensation Sub-period Results...... 90

Table 7.9: Segment Investment, Industry Risk, and Option Grants-Alternative Industry

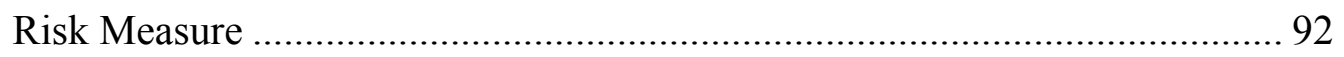

Table 7.10: Segment Investment, Industry Risk, and Vega of Option Holdings.............. 93

Table 7.11: Firm Investment Risk and Compensation Characteristics with Discrete 
Governance Measures

Table 7.12: Firm Investment Risk and Management Team’s Compensation

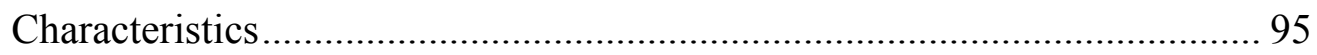

Table 8.1: Segment Investment, Industry Return, and Option Grants........................... 96

Table 8.2: Segment Investment, Industry Return, and Stock Ownership...................... 97 


\section{LIST OF FIGURES}

Figure 1: Average CEO Compensation, Restructuring Sample vs. Market Sample ........ 98

Figure 2: Average Percentage Change of CEO Compensation, Restructuring Sample vs.

Market Sample ........................................................................................ 99 


\section{CHAPTER ONE: INTRODUCTION}

Although numerous studies address whether internal capital markets are efficient in allocating funds, little empirical research investigates the related question of how within-firm capital asset allocation decisions are affected by managerial incentives and particularly by incentives that derive from managers' compensation. The lack of attention to these incentives is puzzling as it would seem important to understand what factors affect a CEO's decisions before reaching a conclusion on the benefits and costs of the internal capital market. Previous studies consider indirect effects on the CEO decision-making process by focusing on the asymmetric information between headquarters and divisions and the rent-seeking behavior of division managers. ${ }^{1}$ These are certainly important features of the internal capital market. In this study, I consider direct effects on CEO decisions by examining the CEOs' own incentives and what benefits they derive from their investment allocation decisions.

Anecdotal evidence suggests that compensation committees generally rely on market and industry standards to set the level and structure of pay, and that pay levels and pay-for-performance sensitivities vary across industries (e.g., Murphy (1998), Bizjak, Lemmon, and Naveen (2000)). Thus the first natural question to be addressed is whether industry pay levels affect a conglomerate CEO's compensation. Using the Compustat Business Segment File and ExecuComp database, I investigate whether a conglomerate CEO's pay is related to the weighted average pay of the industry counterparts of the firm's segments. I find that a conglomerate CEO's compensation is positively related to the synthetic compensation of the firm's segments, although the relation may not be

\footnotetext{
${ }^{1}$ See Stein (2002) for a review of papers on the value consequences and the two-tier agency problem associated with the internal capital market.
} 
strictly monotonic. These results remain robust with the use of various measures of synthetic compensation and with the inclusion of additional control variables, such as firm size and market average compensation; thus, the possibility of endogeneity is reduced.

Given this evidence of the relation between conglomerate CEO compensation and component industry pay, the next step is to investigate whether CEOs change investment allocations in order to influence their compensation, ceteris paribus and whether their compensation increases subsequently. Important underlying assumptions in this analysis are that CEOs care about their future compensation and have the authority to reallocate funds across segments. To address the question of whether CEOs change investment allocations to influence their compensation, I examine whether conglomerate CEOs invest greater amounts in the segments associated with higher pay. Consistent with this hypothesis, I find that multi-segment firms invest more in segments associated with higher levels of industry executive compensation. These results remain after I impose careful controls, including controls for segment size, cash flow, investment opportunity and segment fixed effects.

I also provide an additional analysis by examining whether the compensation effect is more pronounced in a restructuring sub-sample of the segment-year observations associated with changes in the firms' reported segments (either adding new segments or dropping previously reported segments). I hypothesize that firms are more likely to add (drop) segments with greater (lesser) levels of compensation. The evidence suggests that when conglomerate CEOs make these more drastic reallocation decisions, they tend to invest more in segments associated with higher levels of executive compensation. 
To address the second half of the question regarding changes in allocation decisions, i.e., whether CEO compensation increases following the allocation decisions, I again focus on the sub sample of companies that have undergone substantial changes in their segments. My results suggest that both the level and percentage change of CEO compensation are greater for the restructuring firms than for the market sample two years after the segment restructurings, thus providing support for the hypothesis.

With stock options being the fastest-growing and now often the single largest component of executive compensation, a heated debate about their benefits and costs rages on. Thus, in this study, I explicitly examine two mechanisms through which stock options affect firms' internal capital allocation decisions: risk-taking and sensitivity to past performance.

Several recent studies establish the connection between stock options and increased firm risk. ${ }^{2}$ Although executives can increase the risk in a variety of ways, this study focuses on one strategy managers can use to affect firm risk: the allocation of capital expenditures across segments. In particular, I investigate whether executives in multi-segment firms respond to option incentives by investing more in higher-risk segments. Consistent with the risk-taking hypothesis, size-adjusted segment investment is positively related to the industry risk, as measured by the volatility of stock returns, for firms with option grants.

An advantage of these tests, as compared to those used in previous studies on the risk-taking incentives of stock options, is that they reduce the possibility of endogeneity and reverse causation. While previous studies have examined the connection between

\footnotetext{
${ }^{2}$ For example, see Defusco, Johnson, and Zorn (1990); Guay (1999); Cohen, Hall, and Viceria (2000); Coles, Daniel, and Naveen (2003); Daniel, Martin, and Naveen (2003); and Xue (2003).
} 
stock options and various measures of firm risk (e.g., volatility of stock return, bond rating, leverage, investment in $\mathrm{R} \& \mathrm{D}$, and degree of diversification), they have not ruled out the possibility of industry effects in both measures of firm risk and option-grant sensitivity. The tests in this paper, however, examine the capital allocation across segments within the same firm (subject to one set of compensation schemes); thus, it is less likely that the industry effects are driving the relation between segment investment and option incentives.

I then study the risk-taking investment decisions at the firm level. My results suggest that investment in high-risk segments as a fraction of a firm's total investment is positively related to the pay-for-performance sensitivity of the CEO's option-grants. At the same time, these high-risk investments are positively related to their industry Tobin's q. This result remains robust with the inclusion of various control variables and firm fixed-effects.

Adverse incentives created by managerial compensation can potentially be constrained by other elements of a firm's corporate governance structure. In particular, previous evidence shows that corporate governance structures can affect firm investment policy and firm value (Core, Holthausen, and Larker (1999) and Gompers, Ishii, and Metrick (2003)). Thus, to test whether governance structures affect CEO decisions in the context of within-firm capital reallocation, I also include a proxy variable to capture the heterogeneity in shareholder rights/management power. Specifically, I use an antitakeover amendment index developed by Gompers, Ishii, and Metrick (2003). The results suggest that the weaker the shareholder rights, the less investment there is in highrisk segments, which is consistent with the hypothesis that a better corporate governance 
structure mitigates the agency problem (e.g., the underinvestment problem described by Myers (1977)).

Finally, I consider conglomerate CEOs' pay-for-performance sensitivity and the sensitivity of segment investment to past performance. I have somewhat contradictory findings. On the one hand, multi-segment firms with executive option grants seem to invest greater amounts in industries that have done well in the recent past, but those with greater CEO ownerships seem to reverse the pattern.

My contribution is threefold. To the best of my knowledge, this is the first detailed examination of how CEO compensation incentives affect firms' internal capital allocations. While previous work has examined the influence of rent-seeking behavior of division managers and the cross-sectional pattern of cross-subsidization, no previous study has explicitly considered CEOs' own incentives from their compensation contracts. Second, my findings shed light on the capital reallocation process, and point to the importance of additional fundamentals beyond those previously documented in the academic literature. My results suggest that industry pay level is an important consideration for CEOs when allocating funds across segments. Third, my analysis provides a deeper understanding of the effects of compensation incentives on firms' investment decisions.

The remainder of this dissertation is organized as follows. Chapter 2 provides an overview of internal capital markets and executive compensation, and discusses my contribution as compared with previous research that addresses the link between the two. In Chapter 3, I develop the hypotheses. Chapter 4 describes my sample selection and presents descriptive statistics. The construction of variables and research design are 
discussed in Chapter 5. Chapter 6 reports results of the empirical tests. Various robustness checks are performed in Chapter 7. In Chapter 8, I examine the relation between pay-for-performance sensitivity and segment investment-performance sensitivity. Chapter 9 presents the conclusion of this study. 


\section{CHAPTER TWO: LITERATURE REVIEW}

\subsection{OVERVIEW OF INTERNAL CAPITAL MARKETS}

\subsubsection{Active Internal Capital Markets}

To investigate how capital is being allocated to investment projects, it is necessary to examine the capital allocation process not only across firms, but also within firms. I focus on the within-firm aspect of the problem, which is closely related to the operations of internal capital markets. The first question to ask is whether the internal capital market actively reallocates funds across a firm's divisions. A number of recent studies document the existence of active internal capital markets, in the sense that the investment of one division is affected by the cash flow of a firm's other divisions (see, for example, Lamont (1997), Houston, James, and Marcus (1997) and Shin and Stulz (1998)).

Lamont (1997): The first paper to address this question is Lamont (1997), who studies whether oil conglomerates engage in active resource reallocation, moving funds from one division to another. Specifically, he examines whether capital expenditures of non-oil segments of oil companies are affected by the cash flow of the oil segments. Using data from the 1986 oil shock, his evidence suggests that when oil prices drop, oil companies cut investment in all of their divisions. These divisions include not only lines of business that are totally unrelated to oil, but also petrochemical divisions, whose investment prospects should benefit from a decline in oil prices. Given that the operating cash flows of oil companies' non-oil segments generally increase at the time, the fact that they nonetheless reduce their investment seems to suggest that the cash flow of one of a firm's divisions affects the investment of its other divisions. 
Houston, James, and Marcus (1997): Houston, James, and Marcus extend Lamont's (1997) findings to the banking industry by examining the cash flow sensitivity of loan growth at subsidiary banks. Their results are consistent with the existence of internal capital markets operated by bank holding companies to allocate capital among their subsidiaries. In particular, they find that loan growth at subsidiary banks is more sensitive to the holding company's cash flow than to the bank's own cash flow, and that it is negatively correlated with loan growth at the other subsidiaries within the holding company.

Shin and Stulz (1998): Shin and Stulz confirm the finding that internal capital markets play a significant role in reallocating capital across divisions, and further generalize the results to other industries. Using the Compustat business research files, they find that segment investment in highly diversified firms is less sensitive to its own cash flow than for stand-alone firms, which is consistent with the notion that headquarters reallocate resources among segments.

Despite the evidence on active internal capital markets, some question the methodology in these studies. For example, since the relatedness of divisions is usually established using standard industrial classification (SIC) codes, Chevalier (2004) argues that even if a firm has multiple divisions in apparently unrelated SIC codes, it is possible that they may still be related because of a common factor at the firm level. Thus it would not be surprising that the investment of one division is affected by the cash flow of a firm's other divisions. Although this critique contains an important message about experiment design, Lamont (1997) scans for relatedness of divisions using methodologies other than SIC-code comparison, and his original findings remain unchanged. 
Overall, the empirical evidence suggests that internal capital markets engage in active reallocations of funds across divisions.

\subsubsection{Debate on the Efficiency of Internal Capital Markets}

Although it has been well established that internal capital markets play an active role, researchers have not reached consensus on the value consequences of internal capital markets. The literature has identified several mechanisms by which the allocation of funds in an internal capital market can lead to either increases or decreases in efficiency.

First of all, a number of studies consider the potential benefits, besides direct operating synergies, of bringing together multiple businesses under the roof of a single company. On the theory side, recent studies have emphasized the "winner-picking" benefit of integration (e.g., Gertner, Scharfstein and Stein (1994), Stein (1997) and Matsusaka and Nanda (2002)). Gertner, Scharfstein and Stein (1994) examine the strengths and weaknesses of internal capital markets as compared to external capital markets in a simple model, and show that the ownership aspect of internal capital markets leads to more monitoring for the use of capital and better asset redeployability. Matsusaka and Nanda (2002) develop a setting in which internal capital markets allow firms to allocate resources better than external capital markets by provides the firms with real options to avoid external capital markets and the associated deadweight loss.

Stein's (1997) model is perhaps the best known formalization of the idea. He assumes that CEOs in multidivisional firms are relatively more well-informed about the prospects of the firms' divisions than are outside investors, and that CEOs' private benefits are positively correlated with overall investment returns. Thus, as a result of 
CEOs' superior information about project quality and incentives to maximize total return on investment, internal capital markets make value-enhancing reallocations across divisions by picking winner divisions and avoiding losers.

The empirical studies regarding internal capital markets find contradictory results. Two studies (Khanna and Tice (2001) and Maksimovic and Phillips (2002)) find evidence supporting the role of internal capital markets. Khanna and Tice (2001) provide evidence consistent with the winner-picking story, and suggest that the winner-picking function of internal capital markets works best if firms operate in related lines of business. In an examination of capital expenditure decisions of retailers that operate in multiple divisions within the same broad industry, they find that such firms react more efficiently than their stand-alone counterparts when they experience a negative shock to their discount business, i.e., when Wal-Mart enters their markets.

Similarly, using plant-level data from manufacturing firms, Maksimovic and Phillips (2002) examine segment growth in multi-segment firms. They find that the growth of segments is consistent with the predictions of Stein (1997) in that conglomerates allocate resources across segments to their best segments. In particular, they document that firms grow faster in segments that are more productive, especially when they experience positive demand shocks, and that firms take into account the prospects of their other segments to maximize firm value.

Results from both studies suggest that internal capital markets seem to take money away from other divisions to feed the strong ones when they most need it, which is consistent with the winner-picking story from Stein's (1997) model. 
Other empirical studies (e.g., Whited (2001)) suggest that after accounting for measurement error in using Tobin's $\mathrm{q}$ as a proxy for investment opportunities, there is no evidence of inefficient allocation of investment within conglomerates.

Parallel to the discussion of its potential benefits, many recent theoretical papers, including Rajan, Servaes, and Zingales (2000) and Scharfstein and Stein (2000), focus on the mechanisms through which internal capital markets reduce firm value by stressing the agency conflict between division managers and the CEO. Rajan, Servaes, and Zingales (2000) assume that the CEO acts on behalf of shareholders, thus the only agency conflict is between the CEO and division managers. Their model views the capital allocation rules as a tool that the CEO uses to mitigate division managers' inefficient rent-seeking activities. In their setting, the CEO would prefer a "socialist" outcome because a more equal capital allocation increases division managers' incentives to engage in cooperative, joint-surplus maximizing behavior.

In contrast, the key assumption in Scharfstien and Stein (2000) is that there are two tiers of agency, with the CEO being an agent and acting in his own private interests, rather than those of shareholders. In their framework, managers of weak divisions force the CEO to compensate them more highly to retain them by building up their outside options. If the $\mathrm{CEO}$ were himself the principal, he would pay this added compensation in the form of cash. In this case, capital would still be allocated efficiently across divisions. As an agent, however, he may view it as less costly to tilt the capital allocation towards the weaker divisions, because he can save the firm's cash for uses that would benefit him more privately. 
In both models, division managers are portrayed as rent-seeking agents who try to actively persuade the CEO to give them more compensation, power, or resources. All three papers imply socialism in internal capital allocation, with weaker divisions being cross-subsidized by stronger ones.

A variety of empirical studies support this cross-subsidization hypothesis. Berger and Ofek (1995) find that diversified firms overinvest in their bad segments, and that this overinvestment is related to lower firm value. Shin and Stulz (1998) find that more generally, cash flow in one part of the firm affects investment in another part of the firm. Scharfstein (1998) tests predictions from Scharfstein and Stein (2000), and finds that the sensitivity of investment to industry $\mathrm{q}$ is much lower for divisions of a diversified firm than it is for stand-alone firms. Rajan, Servaes, and Zingales (2000) examine segment investment, segment size, and industry q, and find evidence consistent with their theory. They also find that firm value is negatively related to diversity in investment opportunities. Lamont and Polk (2002) find that diversified firms smooth investment across segments compared to the investment of focused firms in the same industry. Billet and Mauer (2003) find similar patterns in segment investment, and also show that financing constraints are driving the relation between internal capital markets and firm value.

The above evidence is consistent with the cross-subsidization hypothesis, suggesting that internal capital markets in diversified firms transfer funds across divisions in a suboptimal manner, and that the divisions do not respond adequately to investment opportunities, in comparison to stand-alone firms. 
Despite the attention paid to diversification as a corporate strategy, research on within-firm capital investment is inconclusive as to whether internal capital markets are efficient in allocating funds across divisions. Before we can completely resolve many of the most interesting and important questions, we have yet to enhance our understanding of the capital allocation process.

\subsection{OVERVIEW OF EXECUTIVE COMPENSATION}

\subsubsection{Practice and Recent Trends in Executive Compensation}

I now turn to a different area in financial research that has attracted much attention from academics and practitioners alike-executive compensation. Both the level and structure of executive compensation have undergone substantial changes in recent years. In this section I document recent trends in CEO compensation.

First, CEOs have enjoyed large gains in compensation, both in absolute terms and relative to other workers. As pointed out by Hall and Liebman (1998), the direct compensation of CEOs, which includes salary, bonus and the value of new stock option grants, increased by 209 percent at the mean and 136 percent at the median in real terms between 1980 and 1994. Mean direct compensation rose from $\$ 810,000$ to $\$ 2.5$ million, and median direct compensation rose from $\$ 623,000$ to $\$ 1.5$ million (in real 1994 dollars). In the meantime, the inflation adjusted growth rate of CEO compensation has increased dramatically relative to the compensation of all other employee groups. Between 1982 and 1994, mean and median CEO compensation increased by 8.8 percent and 6.8 percent per year, respectively, while the average compensation for all workers was almost flat during this period, rising by only 0.6 percent a year. 
Second, the enormous growth in CEO compensation has resulted largely from stock option awards. Changes in the value of stock and stock options completely swamp changes in salary and bonus. Hall and Liebman (1998) document that from 1980 to 1994 mean salary and bonus has risen by 97 percent, and median salary and bonus has risen by 85 percent. During the same time period, the growth in the value of stock option grants has been even more dramatic: the mean value of options increased by 683 percent from $\$ 155,000$ to $\$ 1.2$ million. The median value of option grants rose from $\$ 0$ to $\$ 325,000$. In 1980 thirty percent of the CEOs received stock options awards, while in 1994 seventy percent did. CEO wealth increases due to stock and stock option revaluations are over 50 times larger than those due to increases in salary and bonus. During the early 1990s, stock options replaced base salaries as the single largest component of CEO compensation in most large firms.

Third, there has been an enormous increase in the sensitivity of CEO pay to firm performance, and the increase is largely attributable to increases in the value of stock and stock options. According to Hall and Liebman, the elasticity of CEO compensation to firm value more than tripled from 1.2 in 1980 to 3.9 in 1994 . In response to a 10 percent increase in firm market value, median CEO wealth increases by $\$ 1.25$ million due to stock and stock option revaluations. In contrast, salary and bonus would only increase by $\$ 23,400$ from the same change in firm value. Thus, changes in the value of stock and stock option account for about 98 percent of the relation between pay and performance. Moreover, their estimate of pay to performance elasticity based on stock and stock options is 30 times larger than previous estimates that rely on salary and bonus changes alone. 
In spite of the general trends in executive compensation, there is still substantial heterogeneity in CEO pay practices across firms and industries. A well-documented stylized fact regarding CEO pay is that compensation increases with firm size. For example, Baker, Jensen, and Murphy (1988) examine the relation between CEO cash compensation and firms sales from 1973-1983 and document a pay-sales elasticity in the 0.25 to 0.35 range. This suggests that a firm that is $10 \%$ larger, as measured by total sales, pays its $\mathrm{CEO}$ about 3\% more in cash compensation. In contrast, pay-forperformance sensitivity decreases with firm size. As Murphy (1999) points out, the median pay-for-performance sensitivity for the larger half of the S\&P 500 companies is $\$ 4.36$ per $\$ 1,000$, while that for the smaller half is $\$ 7.69$ per $\$ 1,000$. The median payfor-performance sensitivity for S\&P Mid-Cap and Small-Cap firms are $\$ 15.38$ and $\$ 28.23$ per $\$ 1,000$, respectively. Moreover, CEO pay levels and pay-for-performance sensitivities also vary by industry. For example, levels of compensation and pay-forperformance sensitivities are lower in regulated utilities than in industrial firms, while CEOs in financial companies generally receive higher pay.

Moreover, as Bizjak, Lemmon, and Naveen (2000) indicate, peer groups and competitive benchmarking are frequently used to set CEO and other executive compensation, and two main criterion for selecting peer groups are industry and firm size. In a review of the 1997 compensation committee reports of 100 firms in the S\&P 500 index, they find that 96 of the 100 firms report that peer groups are used in determining CEO compensation. Firms seldom report the exact composition of the peer group used. 92 firms, however, report the use of peer groups based to some degree on size and/or industry. 
In sum, both the level of CEO compensation and the sensitivity of CEO compensation to firm performance have increased sharply during the past two decades, mainly due to the explosion in stock option grants, which now constitute the single largest component of CEO pay. Firm size, industry, and benchmarking are among the sources of the cross-sectional differences in the level and structure of CEO compensation.

\subsubsection{Executive Compensation and Firm Risk}

The growth in executive compensation corresponds with the increase in the amount of research that has focused on how compensation structure affects observable managerial decisions and vice versa. For example, there have been numerous academic studies that examine the association between executive compensation and corporate performance, investment decisions, capital structure, dividend policies, and diversification. The main body of research rests upon the foundation of agency theory. The principal-agent model suggests that managers' pay should be tied to the performance of their firms in order to induce them to take optimal actions (e.g., Jensen and Meckling (1976)). Because managers are risk averse, however, making pay sensitive to firm performance raises the expected level of pay required to compensate them for the risk. The agency model predicts that pay packages are designed to balance the benefits of increased managerial effort against the costs associated with the risk premium necessary to compensate risk averse managers (see, for example, Jensen and Meckling (1976), Haugen and Senbet (1981) and Smith and Stulz (1985)).

The recent explosion in the use of equity-based compensation, in the form of stock and stock option grants, has important implications for the tradeoff between the benefits and costs, and for the design of optimal compensation contracts. One effect of 
this explosion, as documented in the previous section, has been a substantial increase in the sensitivity of CEO wealth to changes in the price of the firm's shares. The sensitivity of CEO wealth to stock price changes is seen as aligning the incentives of managers with the interests of shareholders. Higher sensitivity implies that managers will work harder because managers share gains and losses with shareholders. Another effect of increased sensitivity, however, is to expose managers to more risk. Thus, it is possible that managers will sometimes pass up some value-enhancing projects if those projects are very risky. At the same time, a second aspect of the increase in equity-based compensation potentially offsets this tendency. Executive stock options, by providing convex payoff structures, can potentially mitigate managers' risk-aversion by increasing the sensitivity of CEO wealth to stock price volatility.

Despite the intuitive appeal of this argument, as pointed out by Guay (1999), its validity depends on the manager's utility function--convexity of the payoff structure from options can be more than offset by concavity of the utility function of the risk-averse manager. Moreover, Ross (2003) suggests that there exists no incentive scheme that will make all expected utility maximizers less risk averse. Thus, the main questions are whether the use of equity-based compensation is associated with higher volatility of stock prices and riskier firm policies including financing, investment, and dividend policies. This section reviews theoretical and empirical studies that establish the link between executive compensation and firm risk. Because endogeneity is a major issue when drawing inferences about the causal connection between compensation and firm risk, I am going to present evidence from both sides of the causation. 
Aggarwal and Samwick (1999): The standard principal-agent model suggests a trade-off between inducing the correct amount of effort by the agent and minimizing the amount of risk he is willing to bear. Aggarwal and Samwick test the predictions of the principal-agent model by examining whether executives in firms with more volatile stock prices will have less performance-based compensation. Risk is measured by the variation in stock return volatility across firms. They find that the pay-performance sensitivity of a manager's compensation is inversely related to the variance of the firm's returns. In particular, the pay-performance sensitivity for executives at firms with the least volatile stock prices is greater than the pay-performance sensitivity for executives at firms with the most volatile stock prices. Their findings strongly support the principal-agent model.

Guay (1999): In examining the compensation of 278 corporate CEOs, Guay finds that when compared with common stocks, stock options play an economically significant role in increasing the convexity of the relation between managers' wealth and stock price. The convex relation is defined as the change in the value of managers' stock options and stockholdings for a given change in stock-return volatility. He also documents that the sensitivity of CEO wealth to equity risk is positively related to firms' investment opportunities. He interprets this result as being consistent with the hypothesis that firms are more likely to provide managers with incentives to invest in risky projects when the potential loss from underinvestment in risky value-enhancing projects is greatest. Furthermore, he presents evidence that firms' equity risk is positively related to the convexity provided to CEOs, which is consistent with the risk-taking incentives of option grants. 
Jin (2002): Jin studies the relation between the optimal incentive levels and firms' risk characteristics, and finds that in general the optimal incentive level decreases with firm total risk. He develops a model to examine the respective effects of systematic and nonsystematic risk on executives' incentive levels, and demonstrates that the optimal incentive level decreases with firm-specific risk, but it can either increase or decrease with market risk. For cases in which CEOs can trade the market portfolio to adjust their exposure to market risk, but at the same time must retain firm-specific risk for incentive reasons, the optimal incentive level decreases with firm-specific risk but does not change with market risk. He also empirically tests the predictions of these models by decomposing risk into systematic and nonsystematic risk. He finds that after controlling for the level of systematic risk, nonsystematic risk is negatively related to incentive levels, but finds no significant relation between market risk and incentive levels, holding constant the firm-specific risk component.

These three studies mainly investigate the impact of firm risk on compensation. Their evidence supports the principal-agent model and the design of optimal compensation contracts to mitigate agency problem. On the other hand, the following studies examine the effects of CEO compensation on firm risk.

Cohen, Hall, and Viceira (2000): Cohen, Hall, and Viceira examine the connection between the risk-taking incentives of stock options and various measures of firm risk. They find that CEOs with more options, and options that are more sensitive to volatility, tend to increase firm risk, but the economic significance of the effect is small. They also evaluate the mechanisms through which managers increase firm total risk, and 
find a significantly positive relation between the options' wealth elasticity and the firm's volatility and leverage.

Coles, Daniel, and Naveen (2003): Coles, Daniel, and Naveen document a strong relation between the structure of managerial compensation, option vega in particular, and firms' investment and debt policies. They find that higher levels of incentives from options are associated with riskier policy choices, including more investment in $\mathrm{R} \& \mathrm{D}$, fewer lines of business, higher leverage, and higher stock price volatility.

Daniel, Martin, and Naveen (2003): Daniel, Martin and Naveen draw similar conclusions as those in Cohen, Hall, and Viceira (2000) and Coles, Daniel, and Naveen (2003). They document that firms with more incentives from options have higher bond credit spreads and higher costs of both debt and equity.

Xue (2004): Xue examines the relation between managerial incentives and firms' choice between two innovation strategies: internal R\&D versus external acquisitions. She focuses on the different risk levels and accounting treatment of the two strategies. Internal $\mathrm{R} \& \mathrm{D}$ is considered more risky than acquiring technology externally. Consistent with the hypothesis that risk-seeking incentives created by stock options encourage managers to take more risk, she finds that CEOs receiving more accounting-based compensation are more likely to use external acquisition than internal development through R\&D. In contrast, when CEOs are more highly compensated in stock options, they rely on both strategies to obtain technology. To explain the positive correlation between the use of stock options and external acquisitions, she suggests that although 
acquisitions are less risky than internal $R \& D$, they are still on average more risky than firms' other operations.

Findings from the previous studies are mostly consistent with the hypothesis that stock option grants give managers the incentive to increase firm risk through various investment and financial policy choices.

\subsection{MANAGERIAL INCENTIVES AND INTERNAL CAPITAL MARKETS}

Several papers in the internal capital market literature demonstrate that a connection exists between the cross-sectional pattern of inefficient cross-subsidization and managerial incentives.

Scharfstein and Stein (2000): Scharfstein and Stein (2000) argue that socialism in capital allocation stems from the simultaneous existence of two factors: the rentseeking behavior between division managers and headquarters, and the potential agency problems between headquarters and investors. This is the typical two-tier agency problem associated with multi-segment firms. Without agency problems between headquarters and investors, headquarters would take measures to eliminate rent-seeking in an efficient manner, rather than distort capital allocation. Thus a direct implication of the theory is that investment distortions should be more pronounced in firms with larger agency issue at the top.

Scharfstein (1998): Scharfstein documents conglomerates' inefficient investment behavior. In particular, by analyzing the capital expenditures of 165 diversified conglomerates in 1979, he finds that divisions in industries with good investment opportunities, as measured by a variant of Tobin's q, tend to invest less than their singlesegment industry peers, while divisions in industries with poor investment opportunities 
tend to invest more than their stand-alone industry peers. In addition, he directly tests the prediction proposed by Scharfstein and Stein's (2000) model, and finds that investment inefficiencies are less pronounced in firms where one would expect agency problems to be less severe-firms where top management has a large equity stake. He also presents evidence that where management ownership stakes are high, conglomerates' investment behave more in line with stand-alone firms. His findings seem to suggest that agency problems between corporate headquarters and investors are at the root of the problem.

Wulf (2002): Wulf is mainly concerned with the design of divisional manager compensation contracts to minimize their rent-seeking behavior. She addresses information and incentive problems in internal capital markets by examining the relation between compensation contracts for division managers and capital allocation in multidivisional firms. She finds that firms appear to use these two instruments-compensation incentives linked to firm performance and investment incentives through the capital budgeting process - as substitutes of offset incentives to distort information. In particular, as the proportion of incentive pay for division manager that is based on firm performance increases, segment investment becomes less responsive to segment profitability. She also uses compensation data from a proprietary survey about compensation contracts conducted in 1993 by a leading compensation consulting firm, and finds empirical evidence that is consistent with the hypothesis that division managers' compensation contracts are designed to reduce rent-seeking incentives.

\subsection{CONCLUSION}

There is a lack of attention to the question of how within-firm capital allocation decisions are affected by CEOs' incentives that come from their compensation. Previous 
research mainly investigates the influence of division managers' rent-seeking behavior on firms' investment behavior. In this dissertation, I consider more direct effects on CEO decisions by examining the CEOs' own incentives and how they respond to such incentives through internal capital allocations. A better understanding of the relation between internal capital markets and executive compensation will have important implications for conglomerate investment policies as well as the impact of compensation incentives on firms' investment behavior in general.

In the meantime, although a number of studies have examined the connection between managerial incentives and firms' capital allocation decisions across divisions, the main purpose of the studies is to show how the cross-sectional pattern of crosssubsidization is related to top management incentives. In other words, they investigate under what circumstances the internal capital market makes the worst allocations. They focus on the cross-sectional differences in investment efficiency across firms, while in this study I explicitly examine the investment allocation within a firm. That is, I focus on the issue of which segments within a firm receive more funding and how that is related to CEO compensation.

With regard to executive stock option incentives and firm risk, several recent studies have established the connection between stock options and increased firm risk (e.g., Defusco, Johnson, and Zorn (1990), Guay (1999), Cohen, Hall, and Viceria (2000), Coles, Daniel, and Naveen (2003), Daniel, Martin, and Naveen (2003), and Xue (2003)). The tests in this study differ from the previous work in important ways. Since I investigate investment decisions across segments within a firm, the possibility of endogeneity or reverse causation in the tests is mitigated. The previous studies examine 
the connection between stock options and various measures of firm risk: volatility of stock return, bond rating, leverage, investment in R\&D and degree of diversification. However, it is possible that the results are simply capturing industry effects in the measures of firm risk and option-grant incentives. For instance, in some technology companies, firm risk and option incentives are positively correlated because options are used as an ex ante incentive device since performance is hard to measure. Because the tests in this study examine capital allocation across segments within the same firm (subject to the same compensation scheme), it is less likely that industry effects are driving the correlation between stock options and the observed investment pattern. 


\section{CHAPTER THREE: HYPOTHESES}

In this study I examine the influence of compensation incentives on conglomerates' within-firm capital reallocations. I consider incentives from both the level and structure of compensation. The influence of firm-specific factors on firms' investment decisions is also examined. This chapter develops the hypotheses. Hypothesis One establishes a link between the level of CEO compensation and the synthetic pay in industries associated with the firm's segments. Hypothesis Two tests the effect of the level of compensation on segment investment. Hypothesis Three focuses on the same effect in restructuring firms. Hypothesis Four looks at changes in CEO pay level following restructuring activities. Hypothesis Five and Six test how CEOs respond to risk-seeing incentives of options at the segment and firm-level, respectively.

\subsection{MULTI-SEGMENT FIRMS' CEO COMPENSATION AND INDUSTRY PAY LEVELS}

Bizjak, Lemmon, and Naveen (2000) examine how peer groups and the competitive benchmarking process are used to set CEO and other executive compensation. They find that benchmarking is pervasive and important in setting levels of salaries, bonuses and option awards. For example, in a review of the 1997 compensation committee reports of 100 firms in the S\&P 500 index, they find that 96 firms indicate that they use peer groups or benchmarking in determining the levels of executives' salary, bonus, and option grants. They also find that peer groups are typically firms that are close in size and in similar industries. Their analysis indicates that peer groups have had a nontrivial effect on compensation levels over the period 1992-1998. In particular, they find that CEOs who are paid below the median in total compensation 
of their size and industry peers receive raises that are twice as large relative to the raised received by CEOs who are paid above the median of their peers.

Given the active role of peer groups and benchmarking in setting pay levels, if we view multi-segment firms as portfolios of investments in various industries, it seems reasonable that $\mathrm{CEO}$ compensation of such firms should be tied to pay levels in these related industries. Thus, in Hypothesis One I test whether Bizjak, Lemmon, and Naveen's (2000) findings generalize to multi-segment firms. This hypothesis is based on the assumption that peer groups consideration is an important determinant of executive compensation.

H1: The level of CEO compensation is positively related to the weighted average executive compensation of the industries in which the firm's segments operate.

Although it appears intuitively sound, no study has tested this empirically. Thus as a starting point of this study, I investigate whether a positive relation exists between CEO compensation and the associated industry pay levels.

\subsection{SEGMENT INVESTMENT AND THE LEVEL OF COMPENSATION}

Based on the fact that firms use peer groups and competitive benchmarking to set levels of salaries, bonuses and stock option grants, managers have incentives to actively participate in the construction of peer groups in order to manipulate the compensation process in their favor. Moreover, if multi-segment firms' CEO compensation is positively related to the weighted average pay in the related industries in which the firms' segments operate, it is natural to investigate whether CEOs change investment allocations in order to favorably influence their compensation contract. It is important to examine whether such relation exists after controlling for the other economic factors that might be 
affecting their investment decisions. I want to examine whether conglomerate CEOs allocate capital in certain ways so that they will enjoy higher pay in the future. In particular, I test the following hypothesis:

H2: CEOs of multi-segment firms allocate more funds in segments associated with higher levels of industry pay.

This hypothesis is based on the assumption that CEOs have the power to reallocate funds across segments, and that they are the ones making the final investment decisions. I also control for other economic factors that have previously been shown to affect firms' investment decisions, such as a segment's size, past performance, growth opportunity, and industry (see, for example, Shin and Stulz (1998) and Scharfstein (1998)). Larger segments, segments with better past performances and/or greater growth opportunities may get more funding. Since these factors may be correlated with industry pay levels, I need to control for them in order to examine the marginal effect of segments' pay levels on their capital expenditures. For example, Smith and Watts (1992) suggest that firms with more growth opportunities have higher executive compensation, and use more stock-option awards.

I also provide an additional analysis by examining whether the compensation effect is more pronounced when conglomerate CEOs make more drastic reallocation decisions, such as adding a new segment or dropping an existing segment. This leads to the following hypothesis:

H3: Multi-segment firms are more likely to add (drop) segments with greater (lesser) levels of compensation. 
I isolate more drastic allocation decisions from all other investment decisions by constructing a sub-sample of the segment-year observations associated with changes in the firms' reported segments (either adding new segments or dropping previously reported segments). I examine whether the effect of industry pay is stronger in the restructuring sub-sample of the data.

\subsection{COMPENSATION FOLLOWING SEGMENT RESTRUCTURINGS}

If CEOs engage in reallocation activities in order to influence their future pay checks, we expect their pay level to rise following such reallocations. To observe this effect, I focus on the sample of restructuring firms. If CEO compensation increases due to reallocation activities, then we should observe a similar or stronger effect in the restructuring sample because these firms have made more drastic allocation decisions; thus, their CEOs are more likely to benefit from pay raises. I then compare their pay changes with those of the market sample, and have the following hypothesis:

H4: The change in CEO compensation is relatively greater for firms that have recently restructured than for other firms.

\subsection{SEGMENT INVESTMENT AND STOCK OPTION INCENTIVES}

The single most noticeable change in the structure of executive compensation packages during the past two decades has been the adoption of equity-based incentive pay. Executive stock options have grown from an almost trivial proportion of executive pay to the largest single component. Thus, the incentives created by stock options have become an important part of an executive's compensation incentives. 
Stock options have two important, potentially offsetting, features: on the one hand, stock options provide a direct link between managerial rewards and stock price appreciation, because the payout from exercising options increases dollar for dollar with increases in the stock price. In this respect options can help mitigate the agency problem between managers and stockholders by more closely aligning the fortunes of the two groups. On the other hand, options have an asymmetric payoff and the value of options increases with the volatility of the underlying stock. Thus, options provide managers with incentives to make decisions that increase firm risk, which may or may not be in the best interest of shareholders. I test the existence of these two hypothetical effects by studying the relation between the stock option component of compensation and segment industry risk.

Due to stock options' convex payoff structure, stock options provide managers with incentives to take actions that may increase firm risk. In theory, stock options can result in too much or too little risk depending on the manager's utility function and the compensation contract. ${ }^{3}$ Thus, in the context of internal capital markets, I test this hypothesis:

H5: Firms with executive stock option grants invest more in segments with higher risk.

To test this hypothesis, I differentiate between the investment behavior of option-granting firms and non option-granting firms.

\subsection{COMPENSATION AND FIRM INVESTMENT RISK}

\footnotetext{
${ }^{3}$ See Guay(1999), Hu, Leland, and Senbet (2002) and Ross (2003).
} 
Hypotheses two through five focus on investment decisions at the segment level. In this section, I examine the link between risk and performance measures, and study the risk-taking behavior at the firm-level. I consider the following hypothesis:

H6: Firms with greater option-grant sensitivities are more likely to invest more in industries associated with higher risk.

I use the ratio of a firm's investment in high-risk industries to the firm's total investment to measure the firm's investment risk. I test whether this ratio is positively correlated with option-grant sensitivity.

Core, Holthausen, and Larker (1999) and Gompers, Ishii, and Metrick (2003) suggest that corporate governance affects firms' investment and financing policies. Since corporate governance mechanisms tend to interact with each other (i.e., be substitutes or compliments), better corporate governance may mitigate managers' self-dealing behavior and be interwoven with the need for incentives through compensation. Thus, among the control variables, I include an anti-takeover governance index measure to capture the cross-sectional difference in shareholder rights/management power. 


\section{CHAPTER FOUR: SAMPLE SELECTION AND DESCRIPTIVE STATISTICS}

\subsection{SAMPLE SELECTION}

The firm segment information comes from the Compustat segment research files. FASB-SFAS No. 14 and SEC Regulation S-K require that firms report segment information for fiscal years ending after December 15, 1977. On June 30, 1997, the Financial Accounting Standards Board (FASB) issued the pronouncement for the Statement of Financial Accounting Standards No. 131 Disclosure about Segments of an Enterprise and Related Information (SFAS 131). The statement establishes standards for the way companies report information related to operating segments in their annual and interim financial reports and supersedes SFAS 14, the basis for the Compustat Business Information Files. Due to the changes required under SFAS 131 for the reporting of business segments, a revised Business Information File has been created to allow for the collection of data reported under the new standard. Because of the change due to SFAS 131, Compustat had to create new Segments data. Obviously there would not be data prior to 1997 (the date of SFAS 131), so Compustat went back and did research to fill in pre 1997 segment data that would conform to SFAS 131. But due to the large amount of work required to "backfill" the pre 1997 data, Compustat only went back as far as 1990. Thus segment data is available from 1990 to 2002.

According to Compustat, the sample includes firms that subsequently delisted from Compustat because of mergers, bankruptcies, liquidations, etc. For each business segment, the following variables are included: sales, depreciation, capital expenditures, identifiable total assets, operating profits and SIC code. Segments that do not contain 
complete information on these variables are excluded from the sample. I make the distinction between single-segment and multi-segment firms, where single-segment firms are those that only report a segment in a given year, whereas multi-segment firms report at least two segments in a given year.

The data on CEO compensation come from the Standard \& Poor's ExecuComp database and is available from 1992 through 2002. The ExecuComp database contains compensation data for up to five top executives in the 1,500 firms in the S\&P indices: the 500 firms in the S\&P 500 Index, the 400 firms in the S\&P Midcap Index, and the 600 firms in the S\&P Smallcap Index. The detailed compensation information for CEOs in each firm includes their salary, bonus, stock holdings, option grants and total direct compensation. ${ }^{4}$ Since the sample of firms in ExecuComp is much smaller than that in the Compustat segment research files, a merger of the two datasets results in a total of 8,687 single segment firm-year observations and 7,542 multi-segment firm-year observations, which covers around $83 \%$ of all firms in ExecuComp. In this study I primarily focus on the multi-segment firms, but I use single-segment firms as controls to calculate industry stock returns and risk, median Tobin's q and executive compensation. ${ }^{5}$

All business segments are divided into 48 industries based on their SIC codes and the Fama and French 48-industry definition. Additional firm-level accounting variables come from the Compustat Industrial Annual File, and return, size and volatility data come from CRSP. I also include the Gompers, Ishii, and Metrick (2003) governance

\footnotetext{
${ }^{4}$ In cases where ExecuComp does not indicate which of the executives is the CEO, I assume the executive with the highest salary is the CEO.

${ }^{5}$ Some regressions have fewer observations due to the inclusion of option-grant sensitivity and lagged variables (not all firms grant options every year).
} 
indices constructed from the Investor Responsibility Research Center (IRRC) publications. $^{6}$

\subsection{DESCRIPTIVE STATISTICS}

Table 4.1 presents summary statistics on the principal variables used in this study. The four panels provide information on segment characteristics, firm characteristics, CEO compensation, and aggregate compensation of the top 5 executives, respectively. The mean (median) firm in my sample has 3.3 (3.0) segments, a debt ratio of $0.54(0.55)$, and 10 out of 24 anti-takeover amendments in the firm's charter. The mean (median) segment has capital expenditures that constitute $34 \%(25 \%)$ of the firm's total investment in that year. They have similar shares in the firm's total sales and cash flow. The standard deviation of segment cash flow, however, is very large, reflecting the substantial variation in segment performance. The summary statistics on segment characteristics are, to some extent, consistent with the pattern of cross-subsidization that has previously been documented in the literature; because segments seem to be receiving identical shares in firms' capital expenditures while their past cash flows vary a lot from segment to segment. The average (median) industry Tobin's q is 1.51 (1.36).

The mean (median) CEO total compensation is $\$ 4,191,768(\$ 1,950,588)$, with a mean (median) option-grant sensitivity of $\$ 2.60$ (\$1.04) per $\$ 1,000$ change in shareholder wealth. The average CEO owns $2.96 \%$ of a firm's total shares, while the median is much lower. The mean fraction of compensation paid out in options is $28.04 \%$. These numbers are systematically larger than those reported in previous studies, reflecting the dramatic increase in the level of executive compensation and the use of equity-based

\footnotetext{
${ }^{6}$ Details on the construction of the governance index are provided in Gompers, Ishii, and Metrick (2003).
} 
incentive pay during the 1990s. Other executives' pay level and equity holdings also grew over the years, albeit at a slower rate.

\subsection{INDUSTRY PAY RANKINGS}

Table 4.2 reports rankings of the 48 industries based on the mean, median, and average change of total direct compensation for CEOs in the 48 industries designated by Fama and French (1997), from 1992-2002. Mean and median total direct compensation are based on cross-firm mean and median of CEOs' total direct compensation in standalone firms. Average change in compensation is defined as the cross-firm average of change in CEOs' total direct compensation from the 1992-1997 time period to the 19982002 time period, for stand-alone firms in each of the 48 industries.

Panel A reports rankings based on mean total direct compensation for CEOs. The levels of CEO compensation vary across industries. Confirming stylized facts in previous studies on executive compensation, CEOs in utility companies earn significantly lower levels of compensation than their counterparts in other industries, while CEOs in banks and financial services companies earn higher pay. The level of compensation has increased substantially during the 1990s. Except for 4 industries (Toys, Ships, Txtls, Aero), all have higher pay in the second half of the sub samples. CEOs in beer, computers, and boxes companies enjoy the largest gains in percentage change in mean from 1998-2002. For the computer industry, the pay raises at the top coincide with the tech-stock bubble during the late $90 \mathrm{~s}$.

Panel B reports rankings based on median total direct compensation for CEOs. Industry median compensations are, in most cases, substantially smaller than mean compensations. Compared with Panel A, the relative rankings vary, partly due to the 
small number of observations in some industries, but similar patterns prevail. For example, regulated utilities are very close to the bottom, while financial firms and banks are close to the top. The percentage changes in median are also a lot smaller. Beer and Boxes are still the top two industries in terms of percentage change, but Comps is no longer among the top.

Panel C of Table 4.2 reports industry rankings based on average change (in thousands of dollars) in compensation for CEOs of stand-alone firms. The number of firms in each industries is no greater than those in Panel A and B, because a firm is required to appear at least once in each of the sub-periods in order to calculate the changes. The rankings are more consistent with those based on mean compensation.

\subsection{INVESTMENT IN TECHNOLOGY SEGMENTS}

In this dissertation I primarily examine segment-level investment decisions. Because my sample covers the entire tech-stock bubble, it allows me to document how the average fractions of capital expenditures in high-tech segments have evolved over time. Thus in Table 4.3, I first divide the sample into four sub-periods: two pre-bubble sub-periods 1991-1993, 1994-1996, the bubble sub-period 1997-1999, and the postbubble sub-period 2000-2002. I then calculate the cross-firm average investment in hightech segments as a fraction of a firm's total capital expenditures, and total assets, respectively for the four sub-periods. Following Cochrane (2002), I define high-tech segments as segments with SIC code 737 . His rationale is that 737 is the most common SIC code for stocks on various tech or internet stock indices.

The figures in the table suggest that the average amount spent on tech segments increases over time, especially during the bubble. As indicated by the reported mean 
comparison t-statistics, both ratios go up substantially during the pre-bubble, and the bubble years, while the increase has been much milder afterwards. 


\section{CHAPTER FIVE: METHODOLOGY AND RESEARCH DESIGN}

\subsection{SYNTHETIC COMPENSATION}

The first step in the analysis is to test whether a CEO's pay level is related to average industry compensation at the segment level. Because pay at the segment level is not observable from the data, I need to develop estimates for segment pay levels. To test this hypothesis I construct a measure of synthetic compensation based on the average executive compensation of the industries in which the firm's segments operate. I then investigate the relation between the conglomerate CEO's compensation and the synthetic compensation of the firm's segments.

I use two alternative measures of synthetic segment compensation. The first measure is based on firm size and industry. Firm size is defined by the sales of single segment firms within each industry. Firm sales are used as a proxy for firm size mainly because of the observed consistency in the sensitivity of compensation relative to sales that has been documented in several previous studies (e.g., Baker, Jensen, and Murphy (1988), Rosen (1992)). Firms are divided into the 48 industry sectors designated by Fama and French (1997) according to their 4-digit SIC codes. As suggested by Bizjak, Lemmon, and Naveen (2000), when firms use peer groups and competitive benchmarking to set levels of pay, they tie their pay practices to those of firms that are comparable in size and in similar industries.

To construct a measure in which firm size and industry are the two main considerations in executive compensation, for each of the 48 industries in each year, I regress CEO total direct compensation on firm total sales for all single-segment firms in 
the industry. I use total direct compensation, which includes salary, bonus, newly granted restricted stocks and executive stock option awards, and other forms of long-term compensation. All components of executive pay are considered because the competitive benchmarking process is shown to cover not only salaries and bonuses, but also equitybased incentive pay. The coefficients from the regressions are then able to capture the relation between CEO compensation and firm size (as depicted by firm sales) for each industry. I then define a synthetic compensation for each conglomerate segment as the predicted value from its industry's regression using the segment's actual sales figure. The synthetic compensation measures the level of CEO compensation associated with managing a particular segment, given the size of the segment and the industry in which it operates. Because this measure of synthetic segment compensation is based on the segment's industry and size, both factors work together to determine the pay level.

A second measure of synthetic segment compensation consists of the industry median compensation for all stand-alone CEOs in the segment's industry. It stands for the level of compensation associated with the CEO's management of a segment in a particular industry. Because this measure of synthetic segment compensation is industry specific but not size specific, it does not depend on the actual size of the segment.

With the segment compensation estimates, the total synthetic compensation for a multi-segment firm can be calculated as the weighted average of its segments' synthetic compensation estimates, either the asset-weighted sum of the predicted segment compensation estimates from industry regressions, or the asset-weighted sum of industry median compensation estimates. It is an estimate of the level of CEO compensation given the portfolio of segments and the industries in which the firm's segments operate. 
Because the synthetic segment compensation estimates are constructed from stand-alone firms that are independent from the operations of the multi-segment firm, they capture only the industry-specific component of compensation, but not the firm-specific component. Therefore, endogeneity is less of an issue here. That is, any correlation between the level of CEO compensation and the total synthetic compensation for a multisegment firm is less likely to be due to the total synthetic compensation capturing the firm's own characteristics.

\subsection{THE MODEL: EXPLANATORY VARIABLES AND ESTIMATION EQUATIONS}

\subsubsection{Actual and Synthetic Compensation}

For each conglomerate firm, the actual CEO compensation can then be related to the synthetic compensation built from the estimates for each of the firm's segments. I use the following regression model:

$$
\begin{aligned}
& \text { CEO compensation }_{j t}=\beta_{0}+\beta_{1}\left(\text { synthetic compensation }_{j t}\right. \\
& \left.+\beta_{2} \text { (synthetic compensation }\right)^{2}{ }_{j t}+\eta_{j}+\varepsilon_{j t}
\end{aligned}
$$

This is a simple bi-variate regression with firm fixed effects. All t-statistics are based on panel corrected standard errors. I regress a CEO's total level of compensation on the weighted-average synthetic segment compensation and I also include a square term of the synthetic compensation to capture any possible concavity/ convexity of the relation.

To rule out the possibility that the relation between actual and synthetic compensation is driven by these variables' mutual correlations with the market average compensation or firm size, I re-estimate the model with the inclusion of two additional control variables: 


$$
\begin{aligned}
\text { CEO compensation }_{j t}=\beta_{0} & +\beta_{1}\left({\text { synthetic compensation })_{j t}}\right. \\
& +\beta_{2}(\text { synthetic compensation })^{2}{ }_{j t} \\
& +\beta_{3}(\text { market average } C E O \text { compensation })_{t} \\
& +\beta_{4}(\text { total sales })_{j t}+\eta_{j}+\varepsilon_{j t}
\end{aligned}
$$

Market average CEO compensation is defined as the cross-sectional average of CEOs' total direct compensation across all firms in a given year. Firm total sales is a proxy for firm size.

\subsubsection{Segment Investment and the Level of Compensation}

A positive connection between CEO compensation and the weighted sum of synthetic segment compensations provides a potentially powerful incentive for CEOs to increase their compensation by moving more firm resources into the higher-paying segments, ceteris paribus. That is, with firms using benchmarking to industry and size of segments for CEO pay, the CEOs have incentives to build up the segments of their firms with higher industry compensation levels. I thus posit that after taking into account other segment characteristics that may affect a CEO's decision-making, such as segment size, cash flow and investment opportunities, the CEO will allocate more funds into those segments associated with higher industry pay. To test this hypothesis, I examine whether relative capital expenditures in a segment are related to the weighted average synthetic segment compensation controlling for other decision factors. Specifically I estimate the following model in which segment capital expenditure as a fraction of the firm's total capital expenditure is the independent variable: 


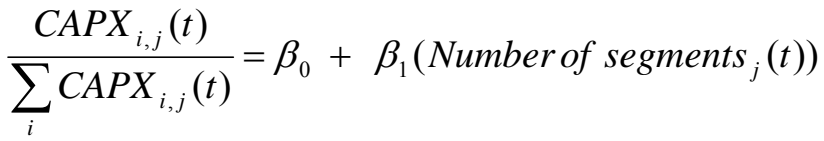

$$
\begin{aligned}
& +\beta_{2}\left(\frac{\operatorname{ASSET}_{i, j}(t-1)}{\sum_{i} \operatorname{ASSET}_{i, j}(t-1)}\right)+\beta_{3}\left(\frac{C F_{i, j}(t-1)}{\sum_{i} C F_{i, j}(t-1)}\right)
\end{aligned}
$$

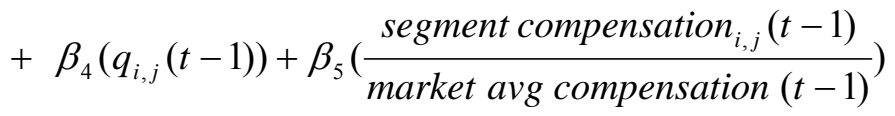

$$
\begin{aligned}
& +\beta_{6} \text { (segment pay for performance sensitivity }_{i, j}(t-1) \\
& +\eta_{i, j}+\varepsilon_{i, j}(t)
\end{aligned}
$$

Where

$C A P X_{i, j}(t)=$ the capital expenditure of the ith segment of firm $\mathrm{j}$ during year $\mathrm{t}$;

$\operatorname{ASSET}_{i, j}(t-1)=$ the book value of the assets of segment $\mathrm{i}$ of firm $\mathrm{j}$ during year $\mathrm{t}-1$;

$C F_{i, j}(t-1)=$ the cash flow of the ith segment of firm $\mathrm{j}$ during year $\mathrm{t}-1$, where cash flow in turn is defined as the sum of operating profits and depreciation.

I include two compensation variables at the segment level as explanatory variables, segment compensation and segment pay-for-performance sensitivity. Segment compensation is the synthetic segment compensation (as defined earlier and estimated from industry cross-sectional regressions) divided by the market average compensation. Segment pay-for-performance sensitivity is defined as the pay-for-performance sensitivity of all stand-alone CEOs in the segment's industry in a particular year. It is estimated from a cross-sectional regression of changes in executive compensation on changes in shareholder wealth. These two variables are of interest because I want to investigate whether industry compensation characteristics play a role in a firm's investment decisions. Segment compensation is a proxy for the relative level of pay while pay-for-performance sensitivity represents the risk-sharing feature implied by compensation contracts. To reduce the possibility of endogeneity and reverse causation, the segment compensation and pay-for-performance sensitivity measures (as well as the 
other control variables to be introduced below) are measured at the end of a firm's prior fiscal year, while the dependent variable, segment proportional capital investment, is measured in a firm's current fiscal year.

Segment fixed-effects are included to accommodate the segment-specific component. I also control for other firm and segment characteristics such as a firm's total number of segments, relative segment size, cash flow, and investment opportunities. Relative segment size is defined as segment assets as a fraction of the firm's total assets. Similarly, segment cash flow is measured as segment cash flow divided by the firm's total cash flow. Although Tobin's q is probably the most commonly used proxy for investment opportunities, it is not a possible proxy here because it cannot be computed at the segment level due to the inability to observe a segment's market value. A viable alternative proxy is to compute the median $\mathrm{q}$ for all single-segment firms in each year in each of the 48 industries designated by Fama and French (1997), and that is the measure used in this paper. ${ }^{7}$

A related hypothesis is that when firms make more drastic reallocation decisions, such as adding or dropping an entire industry segment, the effect of industry compensation on segment investment would be more pronounced. In order to test this hypothesis, I introduce a restructuring dummy and its interaction terms with the segment compensation variables into the regression. This dummy variable takes on the value of one if a firm has any changes in its reported segments, either by adding new segments or dropping existing segments. This sub-sample of firms is associated with more drastic investment decisions. One drawback to this analysis is that in some cases firms may

\footnotetext{
${ }^{7}$ On the definition of Tobin's q I follow Kaplan and Zingales' (1997) method. They measure Tobin's q as the market value of assets divided by the book value of assets.
} 
simply be changing their reporting of existing segments, rather than actually adding or dropping segments. In that case, the noise caused by reporting issues may make it more difficult to measure changes due to restructurings. Since segment research files do not specify the reason or source of changes, adding a segment may be due to: (1) acquiring an existing firm; (2) starting a new segment from scratch; (3) changes in reporting (for example, when the size of an existing segment reaches the reporting threshold of $10 \%$ of firm sales or assets, the firm has to report it). Likewise, dropping a segment may be either due to selling an existing segment or reporting changes. It is virtually impossible to scan for reporting changes given the size and complexity of this dataset. Nevertheless, on average, noise due to reporting should cancel out over time and cross firms, leaving the net effect of restructuring more important.

\subsubsection{Compensation following Segment Restructurings}

If CEOs have incentives to change within-firm asset reallocations to receive higher future compensation, the next question is whether such reallocation decisions actually result in subsequent higher compensation. I investigate whether CEO compensation rises following the active reallocation decisions in the restructuring sample. I compare the level and percentage change of CEO compensation for two samples: the restructuring sample and the market sample, two years after the segment restructuring activities. The restructuring sample is as defined before. The market sample covers all firms in a given year. Through this comparison I can examine whether following major reorganizations, the CEO pay for the restructuring firms increases faster than that of firms in general.

\subsubsection{Segment Investment and Stock Option Incentives}


To investigate whether executives in multi-segment firms respond to option incentives by investing more in higher-risk segments, I consider the following model:

$$
\begin{aligned}
\operatorname{EXCAPX}_{i, j}(t)=\beta_{0} & +\beta_{1}\left(\text { Number of segments }_{j}(t)\right)+\beta_{2}\left(\frac{C F_{i, j}(t-1)}{\sum_{i} C F_{i, j}(t-1)}\right) \\
& +\beta_{3}\left(\text { industry risk }_{i, j}(t-1)\right) \\
& +\beta_{4}\left(\text { option grant dummy }_{j}(t-1) * \text { industry risk }_{i, j}(t-1)\right) \\
& +\beta_{5}\left(\text { option grant dummy }_{j}(t-1)\right)+\beta_{6}\left(q_{i, j}(t-1)\right)+\eta_{i, j}+\varepsilon_{i, j}(t)
\end{aligned}
$$

Where $\quad \operatorname{EXCAPX}_{i, j}(t)=\frac{\frac{\operatorname{CAPX}_{i, j}(t)}{\sum_{i} \operatorname{CAPX} X_{i, j}(t)}-\frac{\operatorname{ASSET}_{i, j}(t-1)}{\sum_{i} A S S E T_{i, j}(t-1)}}{\operatorname{ASSET}_{i, j}(t-1)} \frac{\sum_{i} A S S E T_{i, j}(t-1)}{\text {. }}$.

In order to estimate segment industry risk, I construct a value-weighted monthly return index using all single-segment firms in each of the 48 industries. Segment industry risk is then defined as the standard deviation of the industry return index using industry index returns for the 24 months preceding the segment's current fiscal year. Here the dependent variable is the size-normalized segment investment. This investment measure captures the excess investment in the segment relative to its size within the multi-segment firm. The option-grant dummy equals to one if a CEO receives stock options in the previous year and zero otherwise. Its interaction with the industry risk captures the sensitivity of investment to industry risk conditioned on executive stock option grants. I also control for the total number of segments in a firm, segment cash flow as a fraction of the firm's total cash flow, and industry medina Tobin's q.

\subsubsection{Compensation and Firm Investment Risk}

The purpose of the set of tests in this section is to examine the relation between incentives created by executive stock options and managers' responses to those incentives. In particular, I investigate whether executives in multi-segment firms respond 
to option incentives by investing more in high-risk segments. For each year, I first divide the Fama and French 48 industries into three risk groups based on their industry operating risk. Industry risk is measured as the standard deviation of return on assets where only stand- alone firms are included in the calculation. I then assign each segment-year observation to one of the three risk groups: high risk, medium risk and low risk based on a segment's SIC code and the 48-industry definition.

I test the following model:

(5) $\frac{C A P X^{\text {high risk }}{ }_{j}(t)}{\sum_{i} C A P X_{i, j}(t)}=\beta_{0}+\beta_{1}\left(\right.$ option sensitivity $\left._{j}(t-1)\right)+\beta_{2}\left(\right.$ controls $\left._{j}(t-1)\right)+\eta_{j}+\varepsilon_{j}(t)$, where the dependent variable is a firm's total investment in the high-risk segments as described above divided by the firm's total investment. I use it as a proxy for a firm's investment risk associated with internal capital allocation. I construct the following explanatory variables. Lagged values of all explanatory variables are used in the regressions.

Option sensitivity: on the measure of risk-taking incentives created by options, I use the methodology suggested by previous studies (e.g., Yermack (1995), Hartzell and Starks (2003), Almazan, Hartzell, and Starks (2003)), which proceeds as follows. The BlackScholes option valuation model is used to calculate the delta of each executive option grant, and then the delta is multiplied by the number of options granted and divided by the total number of shares outstanding at the end of the previous fiscal year. ${ }^{8}$ This option sensitivity is a measure of the dollar change in managerial options per $\$ 1,000$ change in shareholder wealth. Sometimes an executive receives multiple option grants in a year, in which case I aggregate the option sensitivities for the executive within the year.

\footnotetext{
${ }^{8}$ I extract dividend yields and stock price volatilities from the CRSP.
} 
Option vega: the sensitivity of the option value with respect to a $100 \%$ change in stock price volatility. I calculate it from the Black-Scholes model and then multiply it by the number of options granted to obtain the total change in CEO's compensation following a change in the stock price volatility. I also aggregate option vegas within each year for each executive. This is yet another measure of the risk-taking incentives created by stock options, and I expect the coefficient to be positive as well.

Stock ownership: a CEO's total equity holdings (excluding options) as a fraction of the firm's total number of shares outstanding at the beginning of the year. This is essentially a stock sensitivity variable since the delta on a restricted stock is equal to one. It represents the dollar change in the value of managerial restricted stocks per $\$ 1,000$ change in shareholder wealth.

Compensation in options: the value of option grants divided by total compensation, where the option value is derived from the Black-Scholes formula. This variable indicates what proportion of the CEO's compensation comes from stock options.

Firm leverage: defined as the ratio of book value of debt to the market value of total assets. I follow the definitions used by Kayhan and Titman (2003). ${ }^{9}$ I control for the leverage ratio because the amount of debt may affect a firm's investment policy. As pointed out by Jensen and Meckling (1976), corporate management has the incentive to substitute a risky project for a less risky project in the presence of debt, and the riskshifting problem has been one of the classic conflict of interest problems in corporate finance. Thus, I want to control for the level of debt in a firm's capital structure in case

\footnotetext{
${ }^{9}$ The book value of debt is defined as total liabilities plus preferred stock minus deferred taxes and convertible debt.
} 
some of the risk-taking incentives created by options are correlated with leverage ratios, which may obscure my inferences.

Firm Tobin's q: a firm-specific measure of performance and investment opportunity.

High-risk segments' investment opportunities: I measure the investment opportunities of the high-risk segments by calculating the average q of the firm's high risk-segments. This is a better measure of investment opportunities than the firm's q constructed from Compustat because the dependent variable is the fraction of investment in high-risk segments, not the firm's total investment. If firms make relatively efficient investment decisions, Tobin's q should be positively related to capital expenditures. It is possible, however, that an empirical test will not find them to be closely related because many previous studies have documented conglomerates' inefficient investment allocations. ${ }^{10}$

Governance index: I also control for the strength of corporate governance by including a takeover defense measure developed by Gompers, Ishii, and Metrick in the analysis. Their index is a proxy for the balance of power between shareholders and managers and has a possible range from 1 to 24 as it indicates the number of anti-takeover amendments in the firm's charter. Gompers, Ishii, and Metrick assume that the higher the index, the more anti-takeover amendments, and the weaker the shareholder rights (the more power management has). The hypothesis is that a firm's investment policy is not only related to managerial incentives and various firm and segment characteristics, but also to the firm's overall strength of governance and shareholder rights. Although the hypothesis does not specifically consider takeover issues (which the Gompers, Ishii, and Metrick index

\footnotetext{
${ }^{10}$ For theoretical studies, see Milgrom (1988), Milgrom and Roberts (1988), Meyer, Milgrom, and Roberts (1992), Wulf (1999), Rajan, Servaes, and Zingales (2000) and Scharfstein and Stein (2000). For empirical studies, see Bilett and Bauer (1998), Scharfstein (1998) and Shin and Stulz (1998).
} 
measures), if the index is a good measure of the balance of power, it should reflect the degree to which managers engage in self-dealing activities.

\subsubsection{Correlation Tables}

I report correlations among the variables in the regressions in the appendix. Correlation 1 reports the correlations among variables used in the compensation regressions of conglomerate CEOs' total direct compensation against conglomerates' synthetic compensation. Correlation 2 depicts the correlations among variables used in the regressions of the ratio of segment investment as a fraction of the firm's total investment on compensation levels. The correlations among variables used in the regressions of the size-adjusted ratio of segment investment as a fraction of the firm's total investment against industry risk and return are included in Correlation 3. Finally, correlations among variables used in the regressions of the ratio of a firm's investment in high-risk segments as a fraction of the firm's total investment against compensation characteristics are reported in Correlation 4. For each set of regressions, I report correlation tables in three years: 1994, 1998 and 2002, which represent the beginning, the middle, and the end of the sample period, respectively. All the correlations in the tables appear normal. 


\section{CHAPTER SIX: RESULTS AND DISCUSSION}

\subsection{ACTUAL AND SYNTHETIC COMPENSATION}

Hypothesis One tests whether the level of CEO compensation is positively related to the weighted average executive compensation of the industries in which the firm's segments operate. The results are presented in Model (1) of Table 6.1. Panel A uses predicted compensation as a measure of segment compensation while Panel B uses industry median compensations. For both models the coefficient on synthetic compensation is positive and significant at the one percent level, suggesting that a conglomerate CEO's compensation is positively related to the synthetic compensation of the firm's segments. The relation is not strictly linear, however, as indicated by the significantly negative coefficient on the square term. In fact the negative coefficient suggests a slightly concave relation between a conglomerate CEO's actual compensation and the synthetic compensation.

My results remain robust to the inclusion of two additional control variables: the average total compensation for all CEOs in a given year and firm size, measured as the firm's total sales. The results are shown in Model (2) of Table 6.1. The coefficients on these two variables are significantly positive at the $1 \%$ level, suggesting that the market level of compensation and firm size are important determinants of CEO compensation. After adding them, the coefficients and t-statistics of the synthetic compensation and its square terms are much smaller, but the patterns still exist. All four coefficients are significant at the 5\% level. The finding suggests that the relationship between CEO compensation and segment-level pay is not due to their correlations with the general level of compensation in the market. 
These results indicate that a CEO's actual compensation is related to industry pay at the segment level. This positive relation creates incentives for managers to invest relatively more in highly compensated industries, thus a natural question to ask is whether CEOs can influence their compensation through investment allocation choices. Thus in the next section, I further investigate whether CEOs take the opportunity to influence their pay structure through internal capital allocation decisions.

\subsection{SEGMENT INVESTMENT AND THE LEVEL OF COMPENSATION}

Hypothesis Two suggests that CEOs of multi-segment firms allocate more funds to segments associated with higher levels of industry pay. The results from tests of this hypothesis through panel regressions are presented in Model (1) of Table 6.2. Consistent with the hypothesis, the coefficient estimate on the segment compensation variable is significantly positive, suggesting that multi-segment firms invest more in segments associated with higher levels of executive compensation. The economic magnitude of the effect, however, is quite mild. A one-standard-deviation increase in segment compensation is associated with a $0.36 \%$ increase in capital expenditure fraction, which is a $1.45 \%(1.06 \%)$ increase for a median (mean) segment. In the meantime, segment pay-for-performance sensitivity, cash flow, and industry median q do not appear to affect segment investment, suggesting that past performance and growth opportunity are not important determinants of segment investment. This is somewhat consistent with previous findings that segment investment does not adequately respond to measures of investment opportunities. In fact, the only other control variables that seem to matter are the total number of segments, and segment size as measured by assets fraction. The total number of segments is negatively related to segment investment by construction. The 
coefficient on segment size is significantly positive, suggesting that larger segments receive more funding from headquarters.

Hypothesis Three states that multi-segment firms are more likely to add (drop) segments with greater (lesser) levels of compensation. I test this hypothesis by dividing the entire sample into two sub-samples. The restructuring sub-sample includes the segment-year observations that are associated with changes in the firms' reported segments. The indicator variable takes on the value of one if a firm has added a new segment or dropped an existing segment in a given year. Interaction terms with the segment compensation and segment par-for-performance sensitivity are also included in the analysis.

As can be seen from the table, the segment compensation effect is evident in this restructuring sub-sample. In fact most of the significance of the coefficient on segment pay level is captured by the interaction term between pay level and the restructuring dummy. A one-standard-deviation increase in synthetic segment compensation in this sample is associated with an additional $0.29 \%$ increase in capital expenditure fraction, which is a $1.17 \%(0.86 \%)$ increase for a median (mean) segment. The evidence suggests that when multi-segment firms make these more drastic reallocation decisions, they tend to invest more in segments associated with higher levels of executive compensation. These results imply that firms are more likely to add or drop segments based on their levels of compensation such that the net effect of these restructurings is to provide the CEO with greater compensation. 


\subsection{COMPENSATION FOLLOWING SEGMENT RESTRUCTURINGS}

Hypothesis Four posits that the change in CEO compensation is greater for restructuring firms than for the overall market following the restructuring activities. By focusing on restructuring firms, I am more likely to observe any increases in CEO compensation because these firms are associated with more dramatic asset reallocations. In particular, I calculate the averages of both the level and percentage change of CEO compensation for restructuring firms two years after their reported changes in segments, and then compare them with the market-wide levels of compensations and percentage changes.

The level of compensation is depicted in Figure 1. The market average CEO compensation increases steadily throughout the 1990s, tops in year 2002, and then declines afterwards. In comparison, the average compensation for restructuring CEOs is much more volatile. However, for six out of seven years, it stays above the market average compensation, and the mean difference of $\$ 703,000$ is significant at the 5\% level with a t-statistic of 2.67 (paired t-test for mean differences is used).

Figure 2 plots the average percentage change of CEO compensation. Again, the restructuring sample almost always has higher growth rate than the market sample, suggesting that the pattern observed in Figure 1 is not due to engogeneity in that restructuring firms have high levels of compensation to begin with. The mean difference of 61 percent is significant at the 5\% level with a t-statistic of 2.96 (again, paired t-test for mean differences is used). 
The evidence is consistent with the hypothesis that following segment restructurings, CEOs benefit from both a higher level of compensation and a faster growth rate in that compensation.

\subsection{SEGMENT INVESTMENT AND STOCK OPTION INCENTIVES}

Hypothesis Five focuses on the relation between stock option incentives and firms' internal capital allocations. It posits that firms with executive stock option grants invest more in segments with higher risk. As suggested by a positive coefficient on the interaction term between the option grant dummy variable and the segment industry risk in Table 6.3, there is a positive relation between size-adjusted segment investment and industry risk for the sub-sample of firms with executive stock option grants, after controlling for other firm and segment characteristics. This result is consistent with the risk-taking incentives created by the convex payoff structure of stock options. The coefficient on the segment industry risk itself, however, is negative, indicating that firms without option awards are less willing to invest in risky segments.

\subsection{COMPENSATION AND FIRM INVESTMENT RISK}

The last hypothesis implies that higher option-grant sensitivities are associated with higher investment risk at the firm level. Model (1) of Table 6.4 reports estimates from regressions of firms' investment in high-risk segments on lagged option-grant sensitivity, option vega and other control variables. Results are based on firm fixed effects and the t-statistics are based on panel corrected standard errors.

The estimated coefficients reported in Model (1) indicate that higher CEO option-

grant sensitivity is associated with more investment in high-risk segments after 
controlling for firm leverage and other variables. Conglomerate CEOs seem to respond to option incentives by investing more in high-risk segments. To see its economic significance, the table implies that a one-standard-deviation increase in a CEO's option sensitivity is associated with an increase in investment in risky segments of 0.0210 $(=0.0033 \times 6.36)$. This is an $8.4 \%(6.15 \%)$ increase in investment for a firm with the median (mean) investment in risky segments.

On the other hand, the coefficient estimate on option vega is small in magnitude and statistically insignificant, suggesting that incentives as measured by vegas do not have much impact on firms' capital allocation policies. Other factors, which include CEO stock ownership, the fraction of CEO compensation that comes from the value of stock options, and firm leverage do not matter much either. There is some evidence that firms that experienced worse performance in the previous year take more risk. Another important result from the table is that firms' high-risk capital expenditures are positively related to the segments' investment opportunities as measured by Tobin's q. The result suggests that when multi-segment firms take on risky projects, these investments are highly sensitive to their industries' past performance or investment opportunities. The effect of $\mathrm{q}$ is both statistically significant (at less than the $1 \%$ level) and economically important. In Model (1), the effect of a one-standard-deviation increase in $\mathrm{q}$ is to increase investment by $49 \%$ (36\%) for a median (mean) firm, which is an enormous impact on a firm's investment policy. To see whether segment investment is more responsive to option sensitivity conditioned on investment opportunities, I also add an interaction term between the option sensitivity and the high-risk segments Tobin's q, but the coefficient turns out insignificantly different from zero, suggesting no such relation. 
In Model (2) of Table 6.4, after incorporating the anti-takeover amendment index into the analysis, the main findings remain unchanged. The option-grant sensitivity is still positively related to the firm investment risk. In addition, consistent with the hypothesis, corporate governance also plays a role in firms' investment decisions. The coefficient on the governance index is significantly negative, suggesting that firms with better governance tend to have riskier investment policies. The evidence is consistent with the hypothesis that a good corporate governance structure will help reduce the agency problem.

Moreover, the coefficient on the market leverage is significantly positive after adding the governance index and indicates that after controlling for corporate governance, the more debt in a firm's capital structure, the larger the fraction of capital expenditure in high-risk segments. This result is consistent with Jensen and Meckling's agency theory, namely that firms with higher leverage have incentives to take on more risk, although I cannot completely rule out the possibility that firms choose to have a higher leverage ratio and a more risky investment policy simultaneously, perhaps in response to incentives created by stock options. After all, managers can increase firm risk through the choice of corporate investment policy and corporate financing policy.

Overall I find that a firm's investment in high-risk segments, as a fraction of the firm's total investment, is positively related to its CEO's option-grant sensitivity. These results provide support for the hypothesis that executive stock options encourage CEOs to engage in risk-taking behavior, even after controlling for the firm's investment opportunities, leverage ratio, and corporate governance. 


\section{CHAPTER SEVEN: ROBUSTNESS CHECKS}

In this chapter I perform a number of robustness checks. The main purpose is to show that the results presented in the previous chapters are robust to the use of alternative measures of firm size, synthetic compensation, investment opportunities, industry risk, and corporate governance. Moreover, the results remain unchanged even after controlling for CEO turnover, tech segment dummy, and aggregating the compensation data at the firm level to include other executives in the analysis. In addition, results are not sensitive to sample selection and the inclusion of year dummies.

\subsection{YEAR DUMMIES IN THE COMPENSATION REGRESSION}

If there are annual effects, or time trend in the level of CEO compensation, the magnitude and significance of the coefficient on synthetic compensation may be overstated. Thus, I control for annual effects by adding year dummies to the regressions in Table 6.1 in place of the market average CEO compensation variable. The results are presented in Table 7.1. After adding the year dummies to Model (1), the significance and magnitude of the coefficient on synthetic compensation become smaller, but remain significant. The time dummies are positive and nearly all are highly significant, suggesting a generally strong, positive time trend in compensation. The coefficients on the time dummies are consistent with the depiction of the market sample in Figure 1, in which the average compensation increases each year until 2000 and then there is a downturn for 2001 and 2002. In Model (2) I include the original control variables form the regressions in Table 6.1, the market average CEO compensation. in this case, most of the time dummies are not significant since much of the annual variation in compensation 
has been captured by the market average CEO compensation. Thus, the market average compensation seems to be a reasonable substitute for time dummies.

\subsection{ALTERNATIVE MEASURE OF FIRM SIZE}

In Table 6.1, firm total sales is used as a proxy for firm size because firm total sales have been documented as an important determinant of pay levels in previous research (e.g., Baker, Jensen, and Murphy (1988) and Rosen (1992)). To test that the results are not sensitive to alternative measures of firm size, I repeat the analysis using the natural logarithm of firm total assets to measure firm size. I report the finding in Table 7.2. The results are very similar to those in Table 6.1, regardless of which measure of synthetic segment compensation is used.

\subsection{CEO TURNOVER}

Evidence from Table 6.2 suggests that multi-segment firms invest more in segments with higher industry pay levels, and that they are more likely to add a new segment or drop an existing segment based on their pay levels. It is possible, however, that other reasons might have caused this result. For example, a change in compensation may attract CEOs with skills needed for these industries. If that is the case, we would observe an increase in segment investments in these industries, not because of the pay levels, but because of the CEOs' expertise. Another possibility is that, as pointed out by Paul (1992), CEOs have incentives to invest in segments that give cleaner signals of their efforts and abilities. If these segments happen to have higher pay levels, my results may be spurious. To rule out these possibilities, I need to control for changes in executivespecific characteristics that may affect segment investment. Thus, I control for CEO 
turnover by tracking changes in executive names, and define a CEO change indicator that takes on the value of one if there has been a change in CEO names.

Results presented in Table 7.3 confirm those reported in Table 6.2. In fact, the coefficients on segment compensation are even larger in Table 7.3, while the coefficients on the CEO change indicator are never significantly different from zero. In Model (2) of Table 7.3, the effect of compensation in the restructuring sample is comparable to that in Model (2) of Table 6.2. The results suggest that the observed compensation effect is not due to CEOs' self selection or a preference for changing segment allocations to obtain a cleaner signal of managerial ability. The sample size is much smaller though, mainly due to the use of the ExecuComp database to track CEO name changes. In contrast, to be included in Table 6.2 only requires a firm to be in Segment Research File, which has a much broader coverage than the ExecuComp database.

\subsection{TECH SEGMENT DUMMY}

In Chapter Four, I document that a time trend exists for investments in tech segments, mainly due to the tech-stock bubble in the late 1990s, and that compensation for CEOs in tech companies also increases dramatically during my sample period. Therefore I need to control for tech segments in order to show that my results are not

driven by these tech segments. Table 7.4 presents the results. They are very similar to those in Table 6.2, suggesting that the effect of compensation is not caused by increased investment in tech segments. 


\subsection{ALTERNATIVE MEASURE OF SYNTHETIC COMPENSATION}

Since synthetic compensation is calculated using the predicted value from the industry regression, it is a linear function of segment sales. Because investment could potentially be correlated with sales, and driving the results, I replace the original synthetic compensation with an alternative measure of synthetic compensation, the slope coefficient in the industry regression. The findings from the modified regression model are shown in Table 7.5. The estimated coefficient on the slope coefficient is smaller in magnitude than that on the original measure of synthetic compensation, but it remains significant. This implies that the higher the industry sales-compensation sensitivity, the greater the investment in a segment.

\subsection{ALTERNATIVE MEASURES OF INVESTMENT OPPORTUNITIES}

So far I have used Tobin's q as a proxy for investment opportunities. If it is not a good measure of investment opportunities, compensation may have picked up something beyond Tobin's q. In this section, I introduce two other measures of investment opportunities used in previous studies: R\&D/Sales and CAPX/PPE. R\&D expenditures divided by total sales is known as the research intensity, and has been used by Skinner (1993) and others. The rationale for the use of this variable is that R\&D expenditures also lead to the acquisition of investment opportunities. The ratio of a firm's capital expenditures divided by net plant property \& equipment (CAPX/PPE ratio) is another proxy for investment opportunities. The motivation for this variable is that capital expenditures are largely discretionary and may lead to the acquisition of new investment opportunities (see, for example, Servaes (1996) and Yermack (1996)). 
Table 7.6 suggests that even after controlling for all three proxies for investment opportunities (they are not highly correlated, thus I include all three in the regressions), my basic results still remain unchanged. Among the three, $R \& D / S a l e s$ seems to be the best measure of investment opportunities, since it is significantly positively related to segment investment.

\subsection{SUB-SAMPLE RESULTS}

By construction, given a firm-year, segment investments as a fraction of the firm's total investment must sum up to one. This should not cause any econometric problems, though, since I am estimating one equation instead of systems of equations. However, to make sure that the results are not sensitive to sample selection bias, I drop the smallest segments from each firm-year, and then re-estimate the equations. The findings in Table 7.7 are even stronger than those of the original sample, confirming that there is no sample selection bias.

I then divide the sample into 3 sub-periods: 1994-1996, 1997-1999, and 20002002. As shown in Table 7.8, the strength of the effect varies by time. It is weaker during the first two sub-periods, and somehow gets stronger in the last sub-period. Overall, the sub-sample results are much weaker, which in turn suggests that at least part of the results is driven by time-series variations.

\subsection{ALTERNATIVE MEASURE OF INDUSTRY RISK}

In calculating the segment industry risk, I first construct a value-weighted monthly return index using all single-segment firms in each of the 48 industries; I then define the segment industry risk as the standard deviation of the industry return index 
based on the 24 months industry index returns prior to the segment's current fiscal year. The 24-month horizon is used in order to easily and accurately calculate the standard deviation on the return series. My results, however, are not sensitive to the use of other longer or shorter horizons. For example, in Table 7.9 I get very similar results when 12 months of industry index returns are used to calculate the standard deviation.

\subsection{VEGA OF OPTION HOLDINGS}

Since the option-grant dummy only indicates whether an executive received newly-granted stock options in the previous year, it is not based on actual option holdings or the riskiness of the options. Thus, as a robustness check, I calculate vega of executives' option holdings using the methodology suggested by Core and Guay (2002). I replace option dummy with vega of holdings. The results, as shown in Table 7.10, suggest that the sensitivity of segment investment to industry risk is not affected by vega. The coefficients on the holding vega and the interaction term have the right signs, but they are not significantly different from zero. In a similar test, I include a dummy variable for options granted in year -2 or -3 , but the coefficients are not significant either. These finding seem to point out that CEOs are more likely to respond to newly-granted options, but not older ones or the riskiness of the option holdings.

\subsection{DISCRETE MEASURES OF CORPORATE GOVERNANCE}

In this study, I consider the effect of corporate governance on firms' investment decisions. In order to measure the effectiveness of a firm's corporate governance system, I use the takeover defense measure by Gompers, Ishii, and Metrick as a proxy for the balance of power between shareholders and top management. The index indicates the 
number of anti-takeover amendments in the firm's charter. Gompers, Ishii, and Metrick assume that the higher the index, the weaker the shareholder rights. In Table 6.4, I treat the governance index as a continuous variable, but if all that matters is the relative effectiveness of the governance structure, then it would be appropriate to use discrete versions of the governance index. Following Gompers, Ishii, and Metrick (2003), I divide all firms into three portfolios: the "Democracy Portfolio", with governance index $\leq 5$, the "Dictatorship Portfolio", with governance index $\geq 14$, and all others in between.

I replace the continuous governance index with the two indicator variables in Table 7.11. The coefficient on the Governance-democracy indicator is significantly positive at the one percent level, while the coefficient on the Governance-dictatorship indicator is significantly negative at the ten percent level. This result is consistent with that from Table 6.4: firms with better corporate governance invest more in risky industries.

\subsection{COMPENSATION OF TOP MANAGEMENT}

All of the empirical tests to this point have focused on the CEO, in isolation from other executives. Thus, all of the analysis has relied on the assumption that the CEOs are making the within-firm capital reallocation decisions. It is also possible, however, that the investment allocation decision is a collective decision made by the top management team. If so, the results should not be sensitive to the relaxation of the assumption that decisions are made by the CEO. To check this, I aggregate the variables constructed from compensation data within each year for the top executives in each firm reported in ExecuComp (up to five executives per firm). The results, presented in Table 7.12, show that the coefficient estimates are nearly identical in both magnitude and sign, to those 
reported in Table 6.4, which in turn implies that other executives' compensation contracts are very similar to those of the CEOs. Therefore, if other executives have the authority to make cross-segment investment decisions, they would also engage in asset reallocations in a manner consistent with the predictions of this study. 


\section{CHAPTER EIGHT: SEGMENT INVESTMENT AND INDUSTRY RETURNS}

In this chapter I examine the influence of stock returns on firms' investment decisions. The momentum strategy of Jegadeesh and Titman (1993) suggests that returns are consistent in 3-, 6- and 12-month intervals. That is, firms that perform the best in those time frames keep performing well, and the returns of the worst performing firms continue to be poor. If executives recognize that investors value momentum, they may make investment decisions based on past industry returns as well, to the extent that they themselves may benefit from these decisions.

With the value of stock options increasing dollar for dollar with increases in the underlying stock price, stock options provide executives with more incentives to take actions to boost stock price. Since executives have the power to reallocate funds among segments, they can invest more in industries with higher recent returns assuming those segments have better future prospects. Moreover, by tilting towards these hot sectors, firms may appear more attractive to some investors, particularly momentum investors. Therefore, I first examine whether firms with executive stock option grants invest more in segments with better past performance.

I calculate the annualized return for each segment-year observation using the 12 months industry index returns prior to the segment's current fiscal year. This annualized return is a measure of past industry performance. I then estimate the following model: 
(6)

$$
\begin{aligned}
& \operatorname{EXCAPX}_{i, j}(t)=\beta_{0}+\beta_{1}\left(\text { Number of segments }{ }_{j}(t)\right)+\beta_{2}\left(\frac{C F_{i, j}(t-1)}{\sum_{i} C F_{i, j}(t-1)}\right) \\
& \left.+\beta_{3} \text { (industry return }_{i, j}(t-1)\right) \\
& +\beta_{4} \text { (option grant dummy }{ }_{j}(t-1) * \text { industry return }_{i, j}(t-1) \text { ) } \\
& +\beta_{5}\left(\text { option grant dummy }{ }_{j}(t-1)\right)+\beta_{6}\left(q_{i, j}(t-1)\right)+\eta_{i, j}+\varepsilon_{i, j}(t)
\end{aligned}
$$

This is very similar to the model in Table 6.3; I simply replaced industry risk with industry return. The result of this analysis is presented in Table 8.1. The coefficient on the option-industry return interaction is significantly positive at the $5 \%$ level, indicating that firms with option grants have segment investment that is more responsive to past industry returns than those that don't have executive stock option grants. In contrast, firms without option grants display the opposite pattern. Further, a segment's own performance as measured by its cash flow, and industry median Tobin's q do not appear to affect its investment.

The results from Table 6.3 and Table 8.1 indicate that the group of firms with executive stock option awards displays very different investment behavior when compared with the other group. In particular, results suggest that firms with executive option grants have a higher correlation between size-adjusted segment investment and industry risk, and a higher correlation between size-adjusted segment investment and past industry returns.

Next, because equity-based compensation in general can be viewed as a proxy for the degree of alignment between shareholder wealth and CEOs' wealth, I employ CEO stock ownership instead of option grant dummy in the regression. I also include its interaction term with the industry return. Table 8.2 contains the results. I observe the exact opposite pattern: the coefficient on the interaction term is significantly negative, 
which implies that the higher the executive's stock ownership, the more negative the relation between segment investment and past returns.

Table 8.1 and 8.2 suggest that stock option grants induce firms to chase hot sectors, while a higher CEO ownership makes them more averse to industries that have done well in the recent past. Although further investigation is necessary to reconcile the somewhat contradictory findings, this is partly attributable to the fundamental difference between the two variables. Option-grant dummy is a measure of flow--changes in option holdings, whereas CEO ownership is a measure of the level of stock ownership, thus they may capture different features of the incentives. It is also possible that better-performing industries are more risky; therefore because options provide CEOs with risk-seeking incentives, investment in these industries would increase for firms granting options. In contrast, since a large stock ownership may make managers more risk-averse, investment in the same industries would decrease for firms with larger CEO stock ownership. 


\section{CHAPTER NINE: CONCLUSION}

Although there is a substantial body of literature on internal capital markets, research remains inconclusive as to whether internal capital markets are efficient in allocating funds across firms' segments. The inconsistent evidence is partly attributable to the lack of understanding of the motivations behind CEOs' within-firm investment decisions. Despite the attention paid to indirect factors that may affect CEOs' decisionmaking process, such as the rent-seeking behavior of division managers, there has been little research on CEOs' own incentives and benefits from their investment decisions. This dissertation is a first step in providing a better understanding of these incentives. In particular, in this study, I investigate how within-firm investment decisions are affected by incentives that derive from CEOs' compensation.

To test a direct implication of the evidence in Bizjak, Lemmon, and Naveen (2000), I first examine the relation between CEO compensation and the synthetic compensation of a firm's segments. The results suggest that conglomerate CEOs' compensation is positively related to the weighted average of component industry compensations. This is consistent with the use of competitive benchmarking and peer groups to set CEO compensation in multi-segment firms, an extension of the conclusion in Bizjak, Lemmon, and Naveen (2000). The results also confirm the active role of segment size and industry in determining CEO pay levels.

The overall results suggest that multi-segment firms appear to invest more in those segments associated with industries that have higher executive compensation. Moreover, the impact of managerial compensation on segment investment is more pronounced in the restructuring sample, when firms make more drastic investment 
decisions, either by adding new segments or by dropping existing ones. The results are consistent with the idea that industry pay level is an important consideration for CEOs when they allocate funds across segments, which points directly to the importance of additional fundamentals in the capital reallocation process beyond those previously documented in the finance literature.

This study also examines the extent to which active reallocation decisions affect CEO compensation afterwards in the sample of restructuring firms. In particular, if CEO compensation increases due to reallocation activities, executives in restructuring firms are more likely to benefit from pay raises as a result of their more drastic allocation decisions. The finding suggests that following segment restructurings, CEOs enjoy both higher levels of compensation and a faster growth rate relative to the market. This result, coupled with the result on investment decisions based on industry pay levels, reflects the general theme that firms are more likely to add or drop segments based on their levels of compensation such that the net effect of these restructurings is to provide the CEOs with higher future compensation.

Examination of the influence of executive stock options on firms' investment decisions suggests that conglomerate CEOs respond to option incentives by investing more in riskier segments, which is consistent with the risk-seeking incentives associated with the convex payoff structure of options. The results also suggest that corporate governance, as reflected in an index of anti-takeover amendments, has a substantial impact on firms' investment choices. In particular, firms with better governance tend to choose riskier investment policies. 
Furthermore, I find evidence that firms with newly granted executive stock options are more likely to invest in industries with higher past returns, whereas firms with greater executive stock ownerships are less likely to do so. This is partly consistent with the difference between options and restricted stocks in inducing executives to take on more risk.

I also find evidence that the pattern of investment in technology segments coincides with the tech-stock bubble in the late 1990s. Analysis of the average fraction of investment in high-tech segments for the four sub-periods reveals that the average amount spent on tech segments increases over time, especially during the bubble. However, the results remain unchanged after controlling for tech segments, indicating that the effect of pay levels on segment investment is not due to the simultaneous increase in investment and compensation in tech segments.

Because endogeneity is a potential problem when drawing inferences about the casual relation between compensation incentives and capital allocation decisions, I deal with the problem in the following ways. First, I use lagged control variables in the regression analyses. Second, I try to account for all other factors that have been documented to affect firms' investment decisions, including size, past performance, and investment opportunities. Third, I use firm and segment fixed effects to accommodate the firm-specific and segment-specific components that are not captured by the control variables.

To the best of my knowledge, this paper is the first to systematically study how CEO compensation incentives relate to firms' capital allocation decisions. A better understanding of this relation will shed new light on conglomerate investment policies as 
well as on the impact of compensation incentives on firms' investment and risk-taking behavior. I find evidence suggesting that both the level and structure of executive compensation affect firms' internal capital allocations, and the results are robust to various sensitivity checks.

In this study, I document how compensation affects CEOs' decision-making process. Here compensation contracts are taken as given, thus I am not examining any assumptions about whether the design of compensation is efficient or not. My findings imply that investment decisions based on compensation can benefit CEOs, but I have not investigated whether they can also benefit shareholders. Therefore, future research can examine the value consequences of CEOs' actions, and their implications for the design of optimal compensation contracts. 


\section{Table 4.1: Summary Statistics}

This table reports the summary statistics for the key variable used in this study. Data on compensation and segment characteristics are available from 1992-2002. Segment Tobin's q is the industry median Tobin's q for all single-segment firms in the industry in a particular year. Governance index indicates the number of anti-takeover amendments in a firm's charter. Option-grant sensitivity is a measure of the dollar change in managerial options per $\$ 1,000$ change in shareholder wealth. Option vega is the sensitivity of the option value with respect to a $100 \%$ change in stock price volatility.

\begin{tabular}{|c|c|c|c|c|c|}
\hline \multicolumn{6}{|l|}{ Panel A. Segment characteristics } \\
\hline Variable & Mean & Median & $\begin{array}{l}\text { Standard } \\
\text { Deviation }\end{array}$ & $\begin{array}{c}10^{\text {th }} \\
\text { percentile }\end{array}$ & $\begin{array}{c}90^{\text {th }} \\
\text { percentile }\end{array}$ \\
\hline Segment investment (as \% of firm total investment) & $34.13 \%$ & $25.00 \%$ & $33.32 \%$ & $1.32 \%$ & $84.85 \%$ \\
\hline Segment sales (as \% of firm total sales) & $33.86 \%$ & $26.38 \%$ & $27.49 \%$ & $3.61 \%$ & $78.35 \%$ \\
\hline Segment cash flow (as \% of firm total cash flow) & $34.12 \%$ & $25.33 \%$ & $210.22 \%$ & $-0.17 \%$ & $88.27 \%$ \\
\hline Segment Tobin's q & 1.51 & 1.36 & 0.61 & 1.04 & 2.03 \\
\hline \multicolumn{6}{|l|}{ Panel B. Firm characteristics } \\
\hline Variable & Mean & Median & $\begin{array}{l}\text { Standard } \\
\text { Deviation }\end{array}$ & $\begin{array}{c}10^{\text {th }} \\
\text { percentile }\end{array}$ & $\begin{array}{c}90^{\text {th }} \\
\text { percentile }\end{array}$ \\
\hline Number of segments & 3.26 & 3.00 & 1.40 & 2.00 & 5.00 \\
\hline Firm leverage & 0.54 & 0.55 & 0.17 & 0.30 & 0.76 \\
\hline Governance index & 9.86 & 10.00 & 2.66 & 6.00 & 13.00 \\
\hline \multicolumn{6}{|l|}{ Panel C. CEO compensation } \\
\hline Variable & Mean & Median & $\begin{array}{l}\text { Standard } \\
\text { Deviation }\end{array}$ & $\begin{array}{c}10^{\text {th }} \\
\text { percentile }\end{array}$ & $\begin{array}{c}90^{\text {th }} \\
\text { percentile }\end{array}$ \\
\hline CEO compensation $(\$ 000 \mathrm{~s})$ & 4192 & 1951 & 8941 & 560 & 8429 \\
\hline Option-grant sensitivity & 2.60 & 1.04 & 6.36 & 0.20 & 5.51 \\
\hline Option vega & 4044 & 1329 & 12482 & 251 & 7983 \\
\hline Stock ownership & $2.96 \%$ & $0.30 \%$ & $7.55 \%$ & $0.03 \%$ & $9.19 \%$ \\
\hline Compensation in options & $28.04 \%$ & $24.21 \%$ & $25.40 \%$ & $0.00 \%$ & $66.22 \%$ \\
\hline \multicolumn{6}{|l|}{ Panel D. Aggregate compensation of top 5 executives } \\
\hline Variable & Mean & Median & $\begin{array}{l}\text { Standard } \\
\text { Deviation }\end{array}$ & $\begin{array}{c}10^{\text {th }} \\
\text { percentile }\end{array}$ & $\begin{array}{c}90^{\text {th }} \\
\text { percentile }\end{array}$ \\
\hline Option-grant sensitivity & 5.39 & 2.35 & 12.29 & 0.46 & 11.53 \\
\hline Option vega & 8069 & 2837 & 22351 & 481 & 16571 \\
\hline Stock ownership & $4.48 \%$ & $0.71 \%$ & $10.19 \%$ & $0.09 \%$ & $13.38 \%$ \\
\hline Compensation in options & $27.77 \%$ & $24.38 \%$ & $22.34 \%$ & $0.00 \%$ & $60.15 \%$ \\
\hline
\end{tabular}




\section{Table 4.2: Industry Pay Rankings}

This table reports industry pay rankings based on industry mean, median, and average change of total direct compensation for CEOs in the 48 industries designated by Fama and French (1997), from 1992-2002. \% changes in mean and median across the two sub-periods are also reported. Average change in compensation is the cross-firm average of change in CEOs' total direct compensation from the 1992-1997 time period to the 1998-2002 time period, for each of the 48 industries. $\mathrm{N}$ is the number of companies in an industry. Only stand-alone firms are included in the calculation.

Panel A. Rankings Based on Mean CEO Total Direct Compensation

\begin{tabular}{|c|c|c|c|c|c|c|c|}
\hline \multirow[b]{2}{*}{ Rank } & \multicolumn{3}{|c|}{ 1992-1997 } & \multicolumn{4}{|c|}{ 1998-2002 } \\
\hline & Industry & $\begin{array}{c}\text { Mean } \\
(\$ 000 \mathrm{~s})\end{array}$ & $\mathrm{N}$ & Industry & $\begin{array}{l}\text { Mean } \\
(\$ 000 \mathrm{~s})\end{array}$ & $\mathrm{N}$ & $\begin{array}{c}\% \text { change } \\
\text { in mean }\end{array}$ \\
\hline 1 & Banks & 8178 & 14 & Beer & 16041 & 3 & 790 \\
\hline 2 & Telcm & 4505 & 35 & Comps & 14342 & 55 & 417 \\
\hline 3 & Fin & 4306 & 37 & Banks & 12148 & 5 & 49 \\
\hline 4 & Smoke & 4079 & 1 & BusSv & 9214 & 143 & 234 \\
\hline 5 & Soda & 3692 & 3 & Telcm & 7645 & 16 & 70 \\
\hline 6 & Hlth & 3247 & 41 & Smoke & 6874 & 1 & 69 \\
\hline 7 & Fun & 3083 & 24 & Rubbr & 6436 & 5 & 223 \\
\hline 8 & Toys & 2958 & 13 & Hlth & 5640 & 18 & 74 \\
\hline 9 & Comps & 2777 & 85 & Trans & 5196 & 33 & 205 \\
\hline 10 & BusSv & 2755 & 191 & Soda & 5176 & 4 & 40 \\
\hline 11 & Insur & 2496 & 46 & Drugs & 4969 & 49 & 215 \\
\hline 12 & Clths & 2348 & 24 & Fin & 4908 & 33 & 14 \\
\hline 13 & Food & 2338 & 31 & Fun & 4859 & 17 & 58 \\
\hline 14 & Txtls & 2337 & 14 & Rtail & 4735 & 100 & 157 \\
\hline 15 & Other & 2231 & 27 & Coal & 4678 & 2 & \\
\hline 16 & Chips & 2138 & 114 & Chips & 4548 & 94 & 113 \\
\hline 17 & MedEq & 2005 & 44 & Insur & 3926 & 18 & 57 \\
\hline 18 & Oil & 2003 & 51 & Cnstr & 3815 & 8 & 276 \\
\hline 19 & Rubbr & 1992 & 8 & LabEq & 3563 & 20 & 149 \\
\hline 20 & Meals & 1865 & 35 & Food & 3437 & 21 & 47 \\
\hline 21 & Rtail & 1844 & 138 & Clths & 3407 & 11 & 45 \\
\hline 22 & Beer & 1803 & 4 & FabPr & 3407 & 5 & 237 \\
\hline 23 & Hshld & 1708 & 26 & Other & 3014 & 12 & 35 \\
\hline 24 & Trans & 1704 & 51 & MedEq & 2814 & 31 & 40 \\
\hline 25 & Chems & 1648 & 37 & Autos & 2786 & 9 & 109 \\
\hline
\end{tabular}




\begin{tabular}{|c|c|c|c|c|c|c|c|}
\hline \multirow[b]{2}{*}{ Rank } & \multicolumn{3}{|c|}{$1992-1997$} & \multicolumn{4}{|c|}{$1998-2002$} \\
\hline & Industry & $\begin{array}{c}\text { Mean } \\
(\$ 000 \mathrm{~s})\end{array}$ & $\mathrm{N}$ & Industry & $\begin{array}{c}\text { Mean } \\
(\$ 000 \mathrm{~s})\end{array}$ & $\mathrm{N}$ & $\begin{array}{l}\% \text { change } \\
\text { in mean }\end{array}$ \\
\hline 26 & Guns & 1583 & 1 & Chems & 2766 & 12 & 68 \\
\hline 27 & Drugs & 1576 & 65 & Mach & 2723 & 24 & 75 \\
\hline 28 & Ships & 1568 & 2 & Hshld & 2720 & 17 & 59 \\
\hline 29 & Mach & 1558 & 40 & Meals & 2621 & 31 & 41 \\
\hline 30 & BldMt & 1498 & 15 & Oil & 2572 & 33 & 28 \\
\hline 31 & Gold & 1456 & 11 & Boxes & 2570 & 3 & 342 \\
\hline 32 & Whlsl & 1447 & 55 & Books & 2498 & 4 & 105 \\
\hline 33 & LabEq & 1432 & 21 & Gold & 2343 & 4 & 61 \\
\hline 34 & Autos & 1331 & 21 & Paper & 2282 & 9 & 72 \\
\hline 35 & Paper & 1325 & 26 & ElcEq & 2275 & 8 & 106 \\
\hline 36 & Aero & 1270 & 3 & Toys & 2134 & 4 & -28 \\
\hline 37 & Steel & 1265 & 31 & BldMt & 2025 & 9 & 35 \\
\hline 38 & Agric & 1251 & 6 & Whlsl & 1889 & 35 & 31 \\
\hline 39 & Books & 1217 & 7 & Steel & 1645 & 15 & 30 \\
\hline 40 & ElcEq & 1106 & 11 & PerSv & 1621 & 11 & 108 \\
\hline 41 & Cnstr & 1015 & 11 & Mines & 1611 & 3 & 108 \\
\hline 42 & FabPr & 1011 & 3 & Ships & 1508 & 1 & -4 \\
\hline 43 & Util & 917 & 63 & Util & 1418 & 24 & 55 \\
\hline 44 & PerSv & 779 & 6 & Txtls & 1417 & 6 & -39 \\
\hline 45 & Mines & 774 & 2 & Agric & 1325 & 2 & 6 \\
\hline 46 & Boxes & 582 & 1 & Aero & 1183 & 1 & -7 \\
\hline
\end{tabular}


Panel B. Rankings Based on Median CEO Total Direct Compensation

\begin{tabular}{|c|c|c|c|c|c|c|c|}
\hline \multirow[b]{2}{*}{ Rank } & \multicolumn{3}{|c|}{$1992-1997$} & \multicolumn{4}{|c|}{$1998-2002$} \\
\hline & Industry & $\begin{array}{l}\text { Median } \\
(\$ 000 \mathrm{~s})\end{array}$ & $\mathrm{N}$ & Industry & $\begin{array}{l}\text { Median } \\
(\$ 000 \mathrm{~s})\end{array}$ & $\mathrm{N}$ & $\begin{array}{l}\% \text { change } \\
\text { in median }\end{array}$ \\
\hline 1 & Smoke & 4079 & 1 & Smoke & 6874 & 1 & 69 \\
\hline 2 & Banks & 3406 & 14 & Beer & 4005 & 3 & 336 \\
\hline 3 & Telcm & 2702 & 35 & Hlth & 3234 & 18 & 104 \\
\hline 4 & Soda & 2641 & 3 & Soda & 3201 & 4 & 21 \\
\hline 5 & Fin & 1952 & 37 & Coal & 2694 & 2 & \\
\hline 6 & Ships & 1700 & 2 & Boxes & 2642 & 3 & 354 \\
\hline 7 & Hlth & 1586 & 41 & Fin & 2453 & 33 & 26 \\
\hline 8 & Toys & 1545 & 13 & Cnstr & 2369 & 8 & 181 \\
\hline 9 & Insur & 1483 & 46 & Banks & 2289 & 5 & -33 \\
\hline 10 & Rubbr & 1426 & 8 & Insur & 2222 & 18 & 50 \\
\hline 11 & Clths & 1395 & 24 & Food & 2136 & 21 & 68 \\
\hline 12 & Comps & 1357 & 85 & FabPr & 1988 & 5 & 107 \\
\hline 13 & LabEq & 1318 & 21 & Autos & 1983 & 9 & 110 \\
\hline 14 & Food & 1268 & 31 & Rubbr & 1933 & 5 & 36 \\
\hline 15 & Aero & 1212 & 3 & Books & 1926 & 4 & 141 \\
\hline 16 & Txtls & 1176 & 14 & Fun & 1923 & 17 & 75 \\
\hline 17 & Chems & 1173 & 37 & Trans & 1888 & 33 & 103 \\
\hline 18 & Rtail & 1169 & 138 & Chips & 1878 & 94 & 63 \\
\hline 19 & Chips & 1151 & 114 & Hshld & 1861 & 17 & 64 \\
\hline 20 & Guns & 1150 & 1 & Rtail & 1852 & 100 & 58 \\
\hline 21 & Hshld & 1132 & 26 & Drugs & 1836 & 49 & 72 \\
\hline 22 & Other & 1123 & 27 & Comps & 1782 & 55 & 31 \\
\hline 23 & BusSv & 1118 & 191 & Mach & 1736 & 24 & 68 \\
\hline 24 & Fun & 1102 & 24 & BusSv & 1719 & 143 & 54 \\
\hline 25 & Oil & 1069 & 51 & Mines & 1685 & 3 & 151 \\
\hline
\end{tabular}




\begin{tabular}{|c|c|c|c|c|c|c|c|}
\hline \multirow[b]{2}{*}{ Rank } & \multicolumn{3}{|c|}{$1992-1997$} & \multicolumn{4}{|c|}{$1998-2002$} \\
\hline & Industry & $\begin{array}{l}\text { Median } \\
(\$ 000 \mathrm{~s})\end{array}$ & $\mathrm{N}$ & Industry & $\begin{array}{l}\text { Median } \\
(\$ 000 \mathrm{~s})\end{array}$ & $\mathrm{N}$ & $\begin{array}{l}\% \text { change } \\
\text { in median }\end{array}$ \\
\hline 26 & Drugs & 1065 & 65 & Paper & 1678 & 9 & 108 \\
\hline 27 & Mach & 1035 & 40 & MedEq & 1676 & 31 & 71 \\
\hline 28 & MedEq & 981 & 44 & Oil & 1576 & 33 & 48 \\
\hline 29 & Gold & 971 & 11 & Clths & 1549 & 11 & 11 \\
\hline 30 & FabPr & 962 & 3 & Telcm & 1491 & 16 & -45 \\
\hline 31 & Meals & 950 & 35 & Chems & 1471 & 12 & 25 \\
\hline 32 & Autos & 945 & 21 & Ships & 1469 & 1 & -14 \\
\hline 33 & Trans & 930 & 51 & Toys & 1453 & 4 & -6 \\
\hline 34 & Beer & 919 & 4 & Other & 1413 & 12 & 26 \\
\hline 35 & Whlsl & 888 & 55 & LabEq & 1365 & 20 & 4 \\
\hline 36 & BldMt & 844 & 15 & Whlsl & 1354 & 35 & 52 \\
\hline 37 & Cnstr & 844 & 11 & Meals & 1268 & 31 & 34 \\
\hline 38 & Agric & 842 & 6 & Txtls & 1245 & 6 & 6 \\
\hline 39 & Paper & 807 & 26 & Aero & 1183 & 1 & -2 \\
\hline 40 & Steel & 802 & 31 & BldMt & 1128 & 9 & 34 \\
\hline 41 & Books & 800 & 7 & Steel & 1126 & 15 & 40 \\
\hline 42 & PerSv & 741 & 6 & PerSv & 1083 & 11 & 46 \\
\hline 43 & ElcEq & 732 & 11 & Agric & 1012 & 2 & 20 \\
\hline 44 & Util & 702 & 63 & Gold & 996 & 4 & 3 \\
\hline 45 & Mines & 671 & 2 & ElcEq & 952 & 8 & 30 \\
\hline 46 & Boxes & 582 & 1 & Util & 729 & 24 & 4 \\
\hline
\end{tabular}


Panel C. Rankings Based on Average Change in CEO Total Direct Compensation

\begin{tabular}{|c|c|c|c|c|c|c|c|}
\hline \multirow[b]{2}{*}{ Rank } & \multicolumn{3}{|c|}{ Avg change } & \multirow[b]{2}{*}{ Rank } & \multicolumn{3}{|c|}{ Avg change } \\
\hline & Industry & $(\$ 000 \mathrm{~s})$ & $\mathrm{N}$ & & Industry & $(\$ 000 \mathrm{~s})$ & $\mathrm{N}$ \\
\hline 1 & Beer & 10163 & 3 & 26 & Oil & 909 & 27 \\
\hline 2 & Banks & 10040 & 4 & 27 & Hshld & 901 & 15 \\
\hline 3 & Comps & 8788 & 45 & 28 & Trans & 891 & 28 \\
\hline 4 & BusSv & 5325 & 107 & 29 & Util & 840 & 22 \\
\hline 5 & Rubbr & 4796 & 5 & 30 & MedEq & 805 & 24 \\
\hline 6 & Fin & 3992 & 15 & 31 & Soda & 714 & 3 \\
\hline 7 & Hlth & 2907 & 15 & 32 & Whlsl & 654 & 29 \\
\hline 8 & Smoke & 2795 & 1 & 33 & Boxes & 477 & 1 \\
\hline 9 & Drugs & 2633 & 44 & 34 & PerSv & 366 & 5 \\
\hline 10 & Rtail & 2594 & 92 & 35 & Steel & 258 & 13 \\
\hline 11 & LabEq & 2585 & 13 & 36 & BldMt & 225 & 7 \\
\hline 12 & Books & 2512 & 2 & 37 & Gold & 214 & 4 \\
\hline 13 & Chips & 2407 & 74 & 38 & Toys & 140 & 4 \\
\hline 14 & Cnstr & 2277 & 5 & 39 & Agric & 5 & 2 \\
\hline 15 & Fun & 2205 & 13 & 40 & Other & -11 & 8 \\
\hline 16 & Insur & 2143 & 14 & 41 & Meals & -49 & 26 \\
\hline 17 & Clths & 2018 & 11 & 42 & Txtls & -170 & 4 \\
\hline 18 & Chems & 1700 & 11 & 43 & FabPr & -410 & 2 \\
\hline 19 & Paper & 1437 & 9 & & & & \\
\hline 20 & ElcEq & 1431 & 5 & & & & \\
\hline 21 & Food & 1295 & 20 & & & & \\
\hline 22 & Telcm & 1185 & 7 & & & & \\
\hline 23 & Mines & 1156 & 2 & & & & \\
\hline 24 & Autos & 1057 & 8 & & & & \\
\hline 25 & Mach & 1010 & 20 & & & & \\
\hline
\end{tabular}




\section{Table 4.3: Investment in Technology Segments}

Panel A shows the average investment in tech segments as a fraction of a firm's total investments and total assets, respectively. TechCAPX is investment in tech segments. Tech segments are segments with SIC code 737. Panel B reports the mean differences between the sub-periods. The null hypotheses are that the means of the differences are zero. T-statistics of the mean-comparison tests are provided in parentheses.

Panel A. Average Investment in Tech Segments

\begin{tabular}{|c|c|c|c|}
\hline & TechCAPX/CAPX & TechCAPX/ASSETS & $\mathrm{N}$ \\
\hline (1) Pre-bubble 1: 1991-1993 & 0.0170 & 0.0014 & 1870 \\
\hline (2) Pre-bubble 2: 1994-1996 & 0.0265 & 0.0029 & 1947 \\
\hline (3) Bubble: $\quad$ 1997-1999 & 0.0562 & 0.0053 & 2812 \\
\hline (4) Post-bubble: 2000-2002 & 0.0683 & 0.0062 & 1715 \\
\hline
\end{tabular}

Panel B. Tests of Differences

\begin{tabular}{ccc}
\hline Mean Difference & TechCAPX/CAPX & TechCAPX/ASSETS \\
\hline$(2)-(1)$ & $0.0095^{* *}$ & $0.0014^{* *}$ \\
& $(2.35)$ & $(2.20)$ \\
$(3)-(2)$ & $0.0297^{* * *}$ & $0.0025^{* * *}$ \\
& $(5.59)$ & $(2.83)$ \\
$(4)-(3)$ & $0.0121^{*}$ & 0.0008 \\
& $(1.86)$ & $(0.85)$ \\
\hline
\end{tabular}

* indicates statistically significant at the $10 \%$ level; ** at the $5 \%$ level; *** at the $1 \%$ level. 


\section{Table 6.1: Actual and Synthetic Compensation}

This table shows the coefficients from regressions of conglomerate CEOs' total direct compensation $(\$ 000 \mathrm{~s})$ against conglomerates' synthetic compensation and its square. The synthetic compensation is the weighted sum of segment compensations. In Panel A, segment compensation is the predicted value from the industry's regression using the segment's actual sales figure. In Panel B, segment compensation is the industry median total compensation for all single-segment CEOs in the industry. The regressions estimate CEO compensation as a function of firm size for all single-segment firms for each industry-year. All business segments are divided into 48 industries based on their SIC codes and the Fama and French 48industry definition. In Model (2) I include firm size as measured by the firm's total sales, and the market average total compensation for all CEOs in that year. Results base on panel regression with fixed effects for firms. Coefficients on firm fixed effects and constants are not reported. All t-statistics are based on the panel corrected standard errors (PCSEs), which adjust for autocorrelation and heteroskedasticity. T-statistics are provided in parentheses.

Dependent variable: CEO compensation

Panel A. Predicted Value from Regression as Synthetic Compensation

\begin{tabular}{|c|c|c|}
\hline Independent Variable & Model (1) & Model (2) \\
\hline Synthetic compensation & $\begin{array}{c}0.1026^{* * *} \\
(4.17)\end{array}$ & $\begin{array}{c}0.0380 * * \\
(2.26)\end{array}$ \\
\hline$(\text { Synthetic compensation) })^{2}$ & $\begin{array}{c}-1.50 \mathrm{E}-07 * * * \\
(-2.68)\end{array}$ & $\begin{array}{c}-9.67 \mathrm{E}-08 * * \\
(-1.98)\end{array}$ \\
\hline Market average CEO compensation & & $\begin{array}{c}0.7042 * * * \\
(11.25)\end{array}$ \\
\hline Total sales & & $\begin{array}{c}0.3363^{* * *} \\
\quad(3.82)\end{array}$ \\
\hline$R^{2}$ & 0.50 & 0.53 \\
\hline Number of observations & 7408 & 7408 \\
\hline
\end{tabular}

Panel B. Industry Median Compensation as Synthetic Compensation

\begin{tabular}{lcc}
\hline Independent Variable & $\begin{array}{c}\text { Model }(1) \\
1.5659^{* * * *}\end{array}$ & $\frac{\text { Model }(2)}{0.4239^{* *}}$ \\
Synthetic compensation & $(8.46)$ & $(2.20)$ \\
& $-5.58 \mathrm{E}-05^{* * *}$ & $-1.7 \mathrm{E}-05^{* * *}$ \\
Synthetic compensation $)^{2}$ & $(-7.65)$ & $(-2.63)$ \\
& & $0.6751^{* * *}$ \\
Market average CEO compensation & $(10.40)$ \\
& & $0.3346^{* * *}$ \\
Total sales & & $(3.95)$ \\
& & 0.53 \\
$R^{2}$ & 0.50 & 7499 \\
Number of observations & 7499 &
\end{tabular}




\section{Table 6.2: Segment Investment and the Level of Compensation}

This table shows the coefficients from regressions of the ratio of segment investment as a fraction of the firm's total investment against number of segments, segment asset as a fraction of firm total asset, segment cash flow as a fraction of firm total cash flow, segment Tobin's q, segment compensation and segment payfor-performance sensitivity. Segment compensation is the synthetic segment compensation divided by the market average compensation. Segment pay-for-performance sensitivity is defined as the pay-forperformance sensitivity of all stand alone firms in the segment's industry in a particular year. It is estimated from a cross-sectional regression of change in executive total compensation on change in shareholder wealth. Segment Tobin's q is the industry median q for all single-segment firms in the industry in a year. All business segments are divided into 48 industries based on their SIC codes and the Fama and French 48industry definition. In Model (2) I include a restructuring dummy and its interactions with the segment compensation and segment pay-for-performance sensitivity. The restructuring dummy equals to one when the segment is associated with a firm that has changed its reported segments by either adding a new segment or dropping an existing segment. Results base on panel regression with fixed effects for segments. Coefficients on segment fixed effects and constants are not reported. All t-statistics are based on the panel corrected standard errors (PCSEs), which adjust for autocorrelation and heteroskedasticity. T-statistics are provided in parentheses.

\begin{tabular}{|c|c|c|}
\hline \multicolumn{3}{|c|}{ Dependent variable: segment investment/firm total investment } \\
\hline Independent Variable & Model (1) & Model (2) \\
\hline Number of segments & $\begin{array}{c}-0.0248 * * * \\
(-7.06)\end{array}$ & $\begin{array}{c}-0.0288^{* * * *} \\
(-8.76)\end{array}$ \\
\hline Segment assets/firm total assets & $\begin{array}{l}0.2229 * * * \\
(3.55)\end{array}$ & $\begin{array}{l}0.2147 * * * \\
\quad(3.49)\end{array}$ \\
\hline Segment cash flow/firm total cash flow & $\begin{array}{l}-0.0013 \\
(-1.17)\end{array}$ & $\begin{array}{l}-0.0013 \\
(-1.19)\end{array}$ \\
\hline Segment Tobin's q & $\begin{array}{r}0.0012 \\
(0.38)\end{array}$ & $\begin{array}{c}0.0011 \\
(0.34)\end{array}$ \\
\hline Segment compensation & $\begin{array}{l}0.0024 * * * \\
(2.61)\end{array}$ & $\begin{array}{l}0.0011 \\
(1.10)\end{array}$ \\
\hline Segment pay-for-performance sensitivity & $\begin{array}{l}0.0001 \\
(0.52)\end{array}$ & $\begin{array}{c}0.00003 \\
(0.23)\end{array}$ \\
\hline Restructuring dummy & & $\begin{array}{l}-0.0164 \\
(-0.58)\end{array}$ \\
\hline Segment compensation * restructuring dummy & & $\begin{array}{c}0.0029 * * \\
(2.38)\end{array}$ \\
\hline $\begin{array}{l}\text { Segment pay-for-performance sensitivity * } \\
\text { restructuring dummy }\end{array}$ & & $\begin{array}{l}0.0003 \\
(0.50)\end{array}$ \\
\hline$R^{2}$ & 0.75 & 0.75 \\
\hline Number of observations & 23070 & 23070 \\
\hline
\end{tabular}




\section{Table 6.3: Segment Investment, Industry Risk, and Option Grants}

This table shows the coefficients from regressions of the size-adjusted ratio of segment investment as a fraction of the firm's total investment against number of segments, segment cash flow as a fraction of the firm's total cash flow, prior segment industry risk, and segment Tobin's q. The dependent variable is the ratio of segment investment as a fraction of the firm's total investment normalized by the ratio of segment assets as a fraction of the firm's total assets in the previous year (subtract the prior asset ratio and then divided by the same ratio). Segment industry risk is defined as the standard deviation of the asset-weighted monthly average stock returns for all single-segment firms in the industry for the 24 months prior to the firm's current fiscal year. Segment Tobin's q is the industry median q for all singlesegment firms in the industry in a year. All business segments are divided into 48 industries based on their SIC codes and the Fama and French 48-industry definition. I also include an option-grant dummy variable and its interaction with the segment return. The option-grant dummy equals to one when the segment is associated with a firm that has compensated its CEO with stock options in the previous year. Results base on panel regression with fixed effects for segments. Coefficients on segment fixed effects and constants are not reported. All t-statistics are based on the panel corrected standard errors (PCSEs), which adjust for autocorrelation and heteroskedasticity. T-statistics are provided in parentheses.

\begin{tabular}{|c|c|}
\hline \multicolumn{2}{|c|}{ Dependent variable: size-adjusted segment investment/firm total investment } \\
\hline Independent Variable & Estimate \\
\hline Number of segments & $\begin{array}{c}-0.6583 * * \\
(-2.15)\end{array}$ \\
\hline Segment cash flow/firm total cash flow & $\begin{array}{c}-0.0709 \\
(-0.96)\end{array}$ \\
\hline Segment industry risk & $\begin{array}{c}-5.2124 * \\
(-1.83)\end{array}$ \\
\hline Option grant dummy $*$ segment industry risk & $\begin{array}{c}6.1837^{*} \\
(1.95)\end{array}$ \\
\hline Option grant dummy & $\begin{array}{l}-0.2627 \\
(-1.17)\end{array}$ \\
\hline Segment Tobin's q & $\begin{array}{c}-0.1927 \\
(-0.68)\end{array}$ \\
\hline$R^{2}$ & 0.44 \\
\hline Number of observations & 7657 \\
\hline
\end{tabular}




\section{Table 6.4: Firm Investment Risk and Compensation Characteristics}

This table shows the coefficients from regressions of the ratio of a firm's investment in high-risk segments as a fraction of the firm's total investment against number of segments, CEO's option-grant sensitivity, option vega, stock ownership, the fraction of compensation in options, firm market leverage, firm's q and the weighted average q of its high-risk segments. Option-grant sensitivity is a measure of the dollar change in managerial options per $\$ 1,000$ change in shareholder wealth. Option vega is the sensitivity of the option value with respect to a $100 \%$ change in stock price volatility. In Model (2) I include a governance index that indicates the number of anti-takeover amendments in a firm's charter. Results base on panel regression with fixed effects for firms. Coefficients on firm fixed effects and constants are not reported. All t-statistics are based on the panel corrected standard errors (PCSEs), which adjust for autocorrelation and heteroskedasticity. T-statistics are provided in parentheses.

\begin{tabular}{lcc}
\hline \multicolumn{2}{c}{ Dependent variable: investment } & in high-risk segments/total investment \\
\hline Independent Variable & Model $(1)$ & \multicolumn{1}{c}{ Model (2) } \\
Number of segments & -0.0076 & -0.0044 \\
& $(-0.72)$ & $(-0.41)$ \\
Option sensitivity & $0.0033^{* *}$ & $0.0035^{* *}$ \\
& $(2.23)$ & $(1.99)$ \\
Option vega & $4.14 \mathrm{E}-07$ & $2.62 \mathrm{E}-07$ \\
& $(0.66)$ & $(0.37)$ \\
CEO stock ownership & 0.2719 & -0.0835 \\
& $(1.68)$ & $-0.46)$ \\
Fraction of compensation in options & -0.0379 & -0.0501 \\
& $(-1.10)$ & $(-1.34)$ \\
Firm leverage & 0.0615 & $0.1483^{* *}$ \\
& $(0.91)$ & $(1.96)$ \\
Firm Tobin's q & $-0.0270^{* *}$ & -0.0190 \\
& $(-1.97)$ & $(-1.08)$ \\
High-risk segments Tobin's q & $0.2014^{* * *}$ & $0.1986^{* * *}$ \\
& $(15.45)$ & $(13.15)$ \\
Governance index & & $-0.0164^{* *}$ \\
& & $(-2.14)$ \\
$R^{2}$ & 0.63 & 0.63 \\
Number of observations & 2983 & 2544 \\
\hline$*$ indicates statistically significant at the $10 \%$ level; ** at the $5 \%$ level; *** at the 1\% level.
\end{tabular}




\section{Table 7.1: Actual and Synthetic Compensation with Year Dummies}

This table shows the coefficients from regressions of conglomerate CEOs' total direct compensation $(\$ 000 \mathrm{~s})$ against conglomerates' synthetic compensation and its square with year dummies. The synthetic compensation is the weighted sum of segment compensations. In Panel A, segment compensation is the predicted value from the industry's regression using the segment's actual sales figure. In Panel B, segment compensation is the industry median total compensation for all single-segment CEOs in the industry. The regressions estimate CEO compensation as a function of firm size for all single-segment firms for each industry-year. All business segments are divided into 48 industries based on their SIC codes and the Fama and French 48-industry definition. In Model (2) I include firm size as measured by the firm's total sales, and the market average total compensation for all CEOs in that year. Results base on panel regression with fixed effects for firms. Coefficients on firm fixed effects and constants are not reported. All t-statistics are based on the panel corrected standard errors (PCSEs), which adjust for autocorrelation and heteroskedasticity. Tstatistics are provided in parentheses.

\section{Dependent variable: CEO compensation}

\section{Panel A. Predicted Value from Regression as Synthetic Compensation}

\begin{tabular}{lcc}
\hline Independent Variable & Model $(1)$ & Model $(2)$ \\
\hline Synthetic compensation & $0.0614^{* *}$ & $0.0384^{* *}$ \\
& $(2.44)$ & $(1.99)$ \\
Synthetic compensation $)^{2}$ & $-1.12 \mathrm{E}-07^{* *}$ & $-9.67 \mathrm{E}-08^{* *}$ \\
& $(-2.09)$ & $(-1.97)$ \\
Market average CEO compensation & & $0.7410^{* * *}$ \\
& & $(9.32)$ \\
Total sales & & $0.3314^{* * *}$ \\
& & $(3.76)$ \\
1993 year dummy & 260.70 & 148.59 \\
& $(0.87)$ & $(0.50)$ \\
1994 year dummy & $789.23^{* *}$ & 340.84 \\
& $(2.40)$ & $(1.09)$ \\
1995 year dummy & $813.46^{* *}$ & 136.45 \\
1996 year dummy & $(2.41)$ & $(0.43)$ \\
& $1909.22^{* * *}$ & $573.54 *$ \\
1997 year dummy & $(5.32)$ & $(1.79)$ \\
1998 year dummy & $2654.40^{* * *}$ & $803.38^{* *}$ \\
& $(7.16)$ & $(2.53)$ \\
1999 year dummy & $2787.85^{* * *}$ & 437.22 \\
& $(7.84)$ & $(1.57)$ \\
2000 year dummy & $3590.44^{* * *}$ & 336.44 \\
2001 year dummy & $(9.12)$ & $(1.15)$ \\
& $4527.02^{* * *}$ & 11.52 \\
2002 year dummy & $(10.96)$ & $(0.57)$ \\
& $4401.38^{* * *}$ & 30.31 \\
$R^{2}$ & $(10.82)$ & $(0.10)$ \\
Number of observations & $3824.13^{* * *}$ & 460.68 \\
$*$ indicates statistically significant at the $10 \%$ level; ** at the $5 \%$ level; ***at the $1 \%$ level. & $(1.37)$ \\
& $(8.73)$ & 0.53 \\
& & 7408 \\
\hline
\end{tabular}


Dependent variable: CEO compensation

\section{Panel B. Industry Median Compensation as Synthetic Compensation}

\begin{tabular}{lcc}
\hline Independent Variable & Model $(1)$ & Model $(2)$ \\
\hline Synthetic compensation & $0.3578^{*}$ & $0.3314^{*}$ \\
& $(1.78)$ & $(1.69)$ \\
Synthetic compensation $)^{2}$ & $1.5 \mathrm{E}-05^{* *}$ & $-1.4 \mathrm{E}-05^{* *}$ \\
& $(-2.16)$ & $(-2.04)$ \\
Market average CEO compensation & & $0.7285^{* * *}$ \\
& & $(8.84)$ \\
Total sales & & $0.3306^{* * *}$ \\
& 295.54 & $(3.89)$ \\
1993 year dummy & $(0.99)$ & 170.39 \\
1994 year dummy & $793.41^{* *}$ & $(0.57)$ \\
& $(2.41)$ & 318.34 \\
1995 year dummy & $822.49^{* *}$ & $(1.02)$ \\
& $(2.37)$ & 125.99 \\
1996 year dummy & $1853.41^{* * *}$ & $(0.39)$ \\
1997 year dummy & $(5.07)$ & 496.46 \\
& $2553.27^{* * *}$ & $(1.53)$ \\
1998 year dummy & $(6.64)$ & $682.32^{* *}$ \\
1999 year dummy & $2868.53^{* * *}$ & $(2.09)$ \\
& $(7.96)$ & 437.22 \\
2000 year dummy & $3628.24^{* * *}$ & $(1.57)$ \\
& $(8.96)$ & 309.06 \\
2001 year dummy & $4627.68^{* * *}$ & $(1.06)$ \\
2002 year dummy & $(11.16)$ & -10.33 \\
& $4450.78^{* * *}$ & $(0.94)$ \\
$R^{2}$ & $(10.73)$ & -8.68 \\
Number of observations & $3782.53^{* * *}$ & $(-0.03)$ \\
$*$ indicates statistically significant at the $10 \%$ level; ** at the & $5 \%$ level; ***at the $1 \%$ level. & 359.96 \\
& $(8.75)$ & $(1.09)$ \\
& 0.51 & 0.53 \\
& & 7499 \\
\hline
\end{tabular}




\section{Table 7.2: Actual and Synthetic Compensation-Alternative Measure of Firm Size}

This table shows the coefficients from regressions of conglomerate CEOs' total direct compensation against conglomerates' synthetic compensation and its square. The synthetic compensation is the weighted sum of segment compensations. In Panel A, segment compensation is the predicted value from the industry's regression using the segment's actual sales figure. In Panel B, segment compensation is the industry median total compensation for all single-segment CEOs in the industry. The regressions estimate CEO compensation as a function of firm size for all single-segment firms for each industry-year. All business segments are divided into 48 industries based on their SIC codes and the Fama and French 48-industry definition. In Model (2) I include firm size as measured by the log of the firm's total assets and the market average total compensation for all CEOs in that year. Results base on panel regression with fixed effects for firms. Coefficients on firm fixed effects and constants are not reported. All t-statistics are based on the panel corrected standard errors (PCSEs), which adjust for autocorrelation and heteroskedasticity. T-statistics are provided in parentheses.

\section{Dependent variable: CEO compensation}

\section{Panel A. Predicted Value from Regression as Synthetic Compensation}

\begin{tabular}{lcc}
\hline Independent Variable & Model (1) & Model (2) \\
Synthetic compensation & $0.1026^{* * *}$ & $0.0566^{* *}$ \\
& $(4.17)$ & $(2.25)$ \\
(Synthetic compensation) & 2 & $-1.06 \mathrm{E}-07^{* *}$ \\
& $(-2.68)$ & $(-1.97)$ \\
Market average CEO compensation & & $0.4569^{* * *}$ \\
& & $(6.45)$ \\
Log of total assets & & $3073.02^{* * *}$ \\
& & $(6.45)$ \\
$R^{2}$ & 0.50 & 0.53 \\
Number of observations & 7408 & 7408 \\
\hline
\end{tabular}

Panel B. Industry Median Compensation as Synthetic Compensation

\begin{tabular}{lcc}
\hline Independent Variable & \multicolumn{1}{c}{ Model $(1)$} & Model $(2)$ \\
Synthetic compensation & $1.5659^{* * *}$ & $0.3343^{*}$ \\
& $(8.46)$ & $(1.71)$ \\
Synthetic compensation $)^{2}$ & $-5.58 \mathrm{E}-05^{* * *}$ & $-1.39 \mathrm{E}-05^{* *}$ \\
& $(-7.65)$ & $(-2.09)$ \\
Market average CEO compensation & & $0.4668^{* * *}$ \\
& & $(6.41)$ \\
Log of total assets & $3114.39^{* * *}$ \\
& & $(6.58)$ \\
$R^{2}$ & 0.50 & 0.52 \\
Number of observations & 7499 & 7499 \\
\hline$*$ indicates statistically significant at the $10 \%$ level; ** at the $5 \%$ level; *** at the $1 \%$ level.
\end{tabular}




\section{Table 7.3: Segment Investment and the Level of Compensation with CEO Turnover}

This table shows the coefficients from regressions of the ratio of segment investment as a fraction of the firm's total investment against number of segments, segment asset as a fraction of firm total asset, segment cash flow as a fraction of firm total cash flow, segment Tobin's q, segment compensation, segment pay-forperformance sensitivity, and an indicator for changes in CEOs. Segment compensation is the synthetic segment compensation divided by the market average compensation. Segment pay-for-performance sensitivity is defined as the pay-for-performance sensitivity of all stand alone firms in the segment's industry in a particular year. It is estimated from a cross-sectional regression of change in executive total compensation on change in shareholder wealth. Segment Tobin's q is the industry median q for all singlesegment firms in the industry in a year. All business segments are divided into 48 industries based on their SIC codes and the Fama and French 48-industry definition. In Model (2) I include a restructuring dummy and its interactions with the segment compensation and segment pay-for-performance sensitivity. The restructuring dummy equals to one when the segment is associated with a firm that has changed its reported segments by either adding a new segment or dropping an existing segment. The CEO change indicator equals to one when the firm has changed its CEO in the previous year. Results base on panel regression with fixed effects for segments. Coefficients on segment fixed effects and constants are not reported. All tstatistics are based on the panel corrected standard errors (PCSEs), which adjust for autocorrelation and heteroskedasticity. T-statistics are provided in parentheses.

\begin{tabular}{|c|c|c|}
\hline \multicolumn{3}{|c|}{ Dependent variable: segment investment/firm total investment } \\
\hline Independent Variable & Model (1) & Model (2) \\
\hline Number of segments & $\begin{array}{l}-0.0182 * * * \\
(-9.20)\end{array}$ & $\begin{array}{l}-0.0221 * * * \\
(-9.24)\end{array}$ \\
\hline Segment assets/firm total assets & $\begin{array}{l}0.3043 * * * \\
(10.30)\end{array}$ & $\begin{array}{l}0.2936^{* * *} \\
\quad(9.81)\end{array}$ \\
\hline Segment cash flow/firm total cash flow & $\begin{array}{l}-0.0009 \\
(-0.39)\end{array}$ & $\begin{array}{l}-0.0009 \\
(-0.39)\end{array}$ \\
\hline Segment Tobin's q & $\begin{array}{c}-0.0041 \\
(-1.09)\end{array}$ & $\begin{array}{c}-0.0038 \\
(-1.02)\end{array}$ \\
\hline Segment compensation & $\begin{array}{l}0.0039 * * * \\
(3.69)\end{array}$ & $\begin{array}{c}0.0020 \\
(1.11)\end{array}$ \\
\hline Segment pay-for-performance sensitivity & $\begin{array}{c}0.00004 \\
(0.32)\end{array}$ & $\begin{array}{l}0.00002 \\
(0.18)\end{array}$ \\
\hline Changes in $\mathrm{CEO}$ & $\begin{array}{l}-0.0015 \\
(-0.38)\end{array}$ & $\begin{array}{l}-0.0017 \\
(-0.44)\end{array}$ \\
\hline Restructuring dummy & & $\begin{array}{r}-0.0169 \\
(-0.87)\end{array}$ \\
\hline Segment compensation $*$ restructuring dummy & & $\begin{array}{l}0.0025^{* *} \\
(2.27)\end{array}$ \\
\hline $\begin{array}{l}\text { Segment pay-for-performance sensitivity * } \\
\text { restructuring dummy }\end{array}$ & & $\begin{array}{l}0.0001 \\
(0.40)\end{array}$ \\
\hline$R^{2}$ & 0.90 & 0.90 \\
\hline Number of observations & 9244 & 9244 \\
\hline
\end{tabular}




\section{Table 7.4: Segment Investment and the Level of Compensation with Tech Dummy}

This table shows the coefficients from regressions of the ratio of segment investment as a fraction of the firm's total investment against number of segments, segment asset as a fraction of firm total asset, segment cash flow as a fraction of firm total cash flow, segment Tobin's q, segment compensation, segment pay-forperformance sensitivity, and an indicator for tech segments. Segment compensation is the synthetic segment compensation divided by the market average compensation. Segment pay-for-performance sensitivity is defined as the pay-for-performance sensitivity of all stand alone firms in the segment's industry in a particular year. It is estimated from a cross-sectional regression of change in executive total compensation on change in shareholder wealth. Segment Tobin's q is the industry median q for all single-segment firms in the industry in a year. All business segments are divided into 48 industries based on their SIC codes and the Fama and French 48-industry definition. In Model (2) I include a restructuring dummy and its interactions with the segment compensation and segment pay-for-performance sensitivity. The restructuring dummy equals to one when the segment is associated with a firm that has changed its reported segments by either adding a new segment or dropping an existing segment. The tech dummy equals to one when the segment's 3-digit SIC code is 737. Results base on panel regression with fixed effects for segments. Coefficients on segment fixed effects and constants are not reported. All t-statistics are based on the panel corrected standard errors (PCSEs), which adjust for autocorrelation and heteroskedasticity. T-statistics are provided in parentheses.

\begin{tabular}{lcc}
\hline \multicolumn{3}{c}{ Dependent variable: segment investment/firm total investment } \\
\hline Independent Variable & Model (1) & Model (2) \\
Number of segments & $-0.0248^{* * *}$ & $-0.0288^{* * *}$ \\
& $(-7.05)$ & $(-8.75)$ \\
Segment assets/firm total assets & $0.2229^{* * *}$ & $0.2148^{* * *}$ \\
& $(3.55)$ & $(3.48)$ \\
Segment cash flow/firm total cash flow & -0.0013 & -0.0013 \\
& $(-1.17)$ & $(-1.19)$ \\
Segment Tobin's q & 0.0012 & 0.0012 \\
& $(0.30)$ & $(0.28)$ \\
Segment compensation & $0.0024^{* * *}$ & 0.0018 \\
& $(2.60)$ & $(1.32)$ \\
Segment pay-for-performance sensitivity & 0.0001 & $3.23 \mathrm{E}-05$ \\
& $(0.53)$ & $(0.26)$ \\
Tech dummy & 0.1044 & 0.1013 \\
& $(1.20)$ & $(1.16)$ \\
Restructuring dummy & & -0.0163 \\
& & $(-0.62)$ \\
Segment compensation * restructuring dummy & & $0.0022^{*}$ \\
& & $(1.81)$ \\
Segment pay-for-performance sensitivity * & & 0.0003 \\
restructuring dummy & & $(0.50)$ \\
$R^{2}$ & 0.75 & 0.75 \\
Number of observations & 23070 & 23070 \\
\hline$*$ indicates statistically significant at the 10\% level; **at the 5\% level; *** at the 1\% level. & \\
& & \\
\hline
\end{tabular}


Table 7.5: Segment Investment and the Level of Compensation with Alternative Measure of Segment Compensation

This table shows the coefficients from regressions of the ratio of segment investment as a fraction of the firm's total investment against number of segments, segment asset as a fraction of firm total asset, segment cash flow as a fraction of firm total cash flow, segment Tobin's q, segment compensation and segment payfor-performance sensitivity. Slope coefficient is from the industry regression of compensation on sales for stand-alone firms. Segment pay-for-performance sensitivity is defined as the pay-for-performance sensitivity of all stand alone firms in the segment's industry in a particular year. It is estimated from a cross-sectional regression of change in executive total compensation on change in shareholder wealth. Segment Tobin's q is the industry median q for all single-segment firms in the industry in a year. All business segments are divided into 48 industries based on their SIC codes and the Fama and French 48-industry definition. In Model (2) I include a restructuring dummy and its interactions with the slope coefficient and segment payfor-performance sensitivity. The restructuring dummy equals to one when the segment is associated with a firm that has changed its reported segments by either adding a new segment or dropping an existing segment. Results base on panel regression with fixed effects for segments. Coefficients on segment fixed effects and constants are not reported. All t-statistics are based on the panel corrected standard errors (PCSEs), which adjust for autocorrelation and heteroskedasticity. T-statistics are provided in parentheses.

\begin{tabular}{lcc}
\hline \multicolumn{2}{c}{ Dependent variable: segment investment/firm total investment } & \\
\hline Independent Variable & Model $(1)$ & Model (2) \\
Number of segments & $-0.0249^{* * *}$ & $-0.0290^{* * *}$ \\
& $(-7.09)$ & $(-8.90)$ \\
Segment assets/firm total assets & $0.2225^{* * *}$ & $0.2143^{* * *}$ \\
& $(3.54)$ & $(3.47)$ \\
Segment cash flow/firm total cash flow & -0.0013 & -0.0013 \\
& $(-1.17)$ & $(-1.18)$ \\
Segment Tobin's q & 0.0007 & 0.0007 \\
& $(0.17)$ & $(0.17)$ \\
Alternative measure of segment compensation & $0.0023^{*}$ & 0.0009 \\
& $(1.89)$ & $(0.83)$ \\
Segment pay-for-performance sensitivity & $9.93 \mathrm{E}-05$ & $3.75 \mathrm{E}-05$ \\
& $(0.54)$ & $(0.29)$ \\
Restructuring dummy & & -0.0172 \\
& & $(-0.74)$ \\
Alternative measure of segment compensation * & & $0.0027^{* *}$ \\
restructuring dummy & & $(2.19)$ \\
Segment pay-for-performance sensitivity * & & 0.0003 \\
restructuring dummy & & $(0.43)$ \\
$R^{2}$ & 0.75 & 0.75 \\
Number of observations & 23070 & 23070 \\
\hline$*$ indicates statistically significant at the $10 \%$ level; ** at the $5 \%$ level; *** at the 1\% level.
\end{tabular}


Table 7.6: Segment Investment and the Level of Compensation with Alternative Measures of
Investment Opportunities

This table shows the coefficients from regressions of the ratio of segment investment as a fraction of the firm's total investment against number of segments, segment asset as a fraction of firm total asset, segment cash flow as a fraction of firm total cash flow, segment Tobin's q, R\&D/Sales, CAPX/PPE, segment compensation and segment pay-for-performance sensitivity. Segment compensation is the synthetic segment compensation divided by the market average compensation. Segment pay-for-performance sensitivity is defined as the pay-for-performance sensitivity of all stand alone firms in the segment's industry in a particular year. It is estimated from a cross-sectional regression of change in executive total compensation on change in shareholder wealth. Segment Tobin's q is the industry median q for all single-segment firms in the industry in a year. $\mathrm{R} \& \mathrm{D} /$ Sales is the industry average $\mathrm{R} \& \mathrm{D} /$ Sales for stand-alone firms. CAPX/PPE is the industry average capital expenditures over net property, plant, and equipment for stand-alone firms. All business segments are divided into 48 industries based on their SIC codes and the Fama and French 48industry definition. In Model (2) I include a restructuring dummy and its interactions with the segment compensation and segment pay-for-performance sensitivity. The restructuring dummy equals to one when the segment is associated with a firm that has changed its reported segments by either adding a new segment or dropping an existing segment. Results base on panel regression with fixed effects for segments. Coefficients on segment fixed effects and constants are not reported. All t-statistics are based on the panel corrected standard errors (PCSEs), which adjust for autocorrelation and heteroskedasticity. T-statistics are provided in parentheses.

\begin{tabular}{|c|c|c|}
\hline \multicolumn{3}{|c|}{ Dependent variable: segment investment/firm total investment } \\
\hline Independent Variable & Model (1) & Model (2) \\
\hline Number of segments & $\begin{array}{c}-0.0249 * * * \\
(-7.10)\end{array}$ & $\begin{array}{c}-0.0289^{* * * *} \\
(-8.81)\end{array}$ \\
\hline Segment assets/firm total assets & $\begin{array}{l}0.2226 * * * \\
(3.55)\end{array}$ & $\begin{array}{l}0.2143 * * * \\
\quad(3.48)\end{array}$ \\
\hline Segment cash flow/firm total cash flow & $\begin{array}{l}-0.0013 \\
(-1.17)\end{array}$ & $\begin{array}{l}-0.0013 \\
(-1.18)\end{array}$ \\
\hline Segment Tobin's q & $\begin{array}{r}0.0022 \\
(0.56)\end{array}$ & $\begin{array}{c}0.0022 \\
(0.53)\end{array}$ \\
\hline $\mathrm{R} \& \mathrm{D} /$ Sales & $\begin{array}{l}0.0019^{* *} \\
(2.29)\end{array}$ & $\begin{array}{l}0.0019 * * \\
(2.35)\end{array}$ \\
\hline CAPX/PPE & $\begin{array}{l}-0.0013 \\
(-0.26)\end{array}$ & $\begin{array}{l}-0.0013 \\
(-0.26)\end{array}$ \\
\hline Segment compensation & $\begin{array}{l}0.0025 * * * \\
(2.63)\end{array}$ & $\begin{array}{c}0.0018 \\
(1.28)\end{array}$ \\
\hline Segment pay-for-performance sensitivity & $\begin{array}{l}9.46 \mathrm{E}-05 \\
(0.51)\end{array}$ & $\begin{array}{l}2.63 \mathrm{E}-05 \\
(0.21)\end{array}$ \\
\hline Restructuring dummy & & $\begin{array}{l}-0.0165 \\
(-0.89)\end{array}$ \\
\hline Segment compensation $*$ restructuring dummy & & $\begin{array}{l}0.0024 * * \\
(2.15)\end{array}$ \\
\hline $\begin{array}{l}\text { Segment pay-for-performance sensitivity * } \\
\text { restructuring dummy }\end{array}$ & & $\begin{array}{l}0.0004 \\
(0.52)\end{array}$ \\
\hline$R^{2}$ & 0.75 & 0.75 \\
\hline Number of observations & 23070 & 23070 \\
\hline
\end{tabular}




\section{Table 7.7: Segment Investment and the Level of Compensation without Smallest Segments}

This table shows the coefficients from regressions of the ratio of segment investment as a fraction of the firm's total investment against number of segments, segment asset as a fraction of firm total asset, segment cash flow as a fraction of firm total cash flow, segment Tobin's q, segment compensation and segment payfor-performance sensitivity. For every firm-year, I exclude the smallest segment. Segment compensation is the synthetic segment compensation divided by the market average compensation. Segment pay-forperformance sensitivity is defined as the pay-for-performance sensitivity of all stand alone firms in the segment's industry in a particular year. It is estimated from a cross-sectional regression of change in executive total compensation on change in shareholder wealth. Segment Tobin's q is the industry median q for all single-segment firms in the industry in a year. All business segments are divided into 48 industries based on their SIC codes and the Fama and French 48-industry definition. In Model (2) I include a restructuring dummy and its interactions with the segment compensation and segment pay-for-performance sensitivity. The restructuring dummy equals to one when the segment is associated with a firm that has changed its reported segments by either adding a new segment or dropping an existing segment. Results base on panel regression with fixed effects for segments. Coefficients on segment fixed effects and constants are not reported. All t-statistics are based on the panel corrected standard errors (PCSEs), which adjust for autocorrelation and heteroskedasticity. T-statistics are provided in parentheses.

\begin{tabular}{lcc}
\hline \multicolumn{2}{c}{ Dependent variable: segment investment/firm total investment } & \\
\hline Independent Variable & Model (1) & Model (2) \\
Number of segments & $-0.0300^{* * *}$ & $-0.0363^{* * *}$ \\
& $(-13.15)$ & $(-13.29)$ \\
Segment assets/firm total assets & $0.2416^{* * *}$ & $0.2258^{* * *}$ \\
& $(9.62)$ & $(8.82)$ \\
Segment cash flow/firm total cash flow & -0.0012 & -0.0012 \\
& $(-0.62)$ & $(-0.65)$ \\
Segment Tobin's q & 0.0029 & 0.0027 \\
& $(0.56)$ & $(0.53)$ \\
Segment compensation & $0.0031^{* * *}$ & 0.0012 \\
& $(3.61)$ & $(1.22)$ \\
Segment pay-for-performance sensitivity & 0.0001 & 0.0001 \\
& $(0.79)$ & $(0.56)$ \\
Restructuring dummy & & -0.0248 \\
& & $(-0.77)$ \\
Segment compensation * restructuring dummy & & $0.0024^{* *}$ \\
& & $(2.38)$ \\
Segment pay-for-performance sensitivity * & & 0.0003 \\
restructuring dummy & & $(0.61)$ \\
$R^{2}$ & 0.82 & 0.82 \\
Number of observations & 14729 & 14729 \\
\hline * indicates statistically significant at the $10 \%$ level; ** at the $5 \%$ level; *** at the 1\% level. &
\end{tabular}




\section{Table 7.8: Segment Investment and the Level of Compensation Sub-period Results}

This table shows the coefficients from regressions of the ratio of segment investment as a fraction of the firm's total investment against number of segments, segment asset as a fraction of firm total asset, segment cash flow as a fraction of firm total cash flow, segment Tobin's q, segment compensation and segment payfor-performance sensitivity for three sub-periods 1994-1996, 1997-1999, and 2000-2002. Segment compensation is the synthetic segment compensation divided by the market average compensation. Segment pay-for-performance sensitivity is defined as the pay-for-performance sensitivity of all stand alone firms in the segment's industry in a particular year. It is estimated from a cross-sectional regression of change in executive total compensation on change in shareholder wealth. Segment Tobin's q is the industry median q for all single-segment firms in the industry in a year. All business segments are divided into 48 industries based on their SIC codes and the Fama and French 48-industry definition. In Model (2) I include a restructuring dummy and its interactions with the segment compensation and segment pay-for-performance sensitivity. The restructuring dummy equals to one when the segment is associated with a firm that has changed its reported segments by either adding a new segment or dropping an existing segment. Results base on panel regression with fixed effects for segments. Coefficients on segment fixed effects and constants are not reported. All t-statistics are based on the panel corrected standard errors (PCSEs), which adjust for autocorrelation and heteroskedasticity. T-statistics are provided in parentheses.

Panel A. Sub-period 1994-1996

\begin{tabular}{lcc}
\hline \multicolumn{2}{c}{ Dependent variable: segment investment/firm total investment } & \\
\hline Independent Variable & Model $(1)$ & Model (2) \\
\hline Number of segments & $-0.0150^{* * *}$ & $-0.0247^{* * *}$ \\
& $(-3.92)$ & $(-4.29)$ \\
Segment assets/firm total assets & $0.1380^{* * *}$ & $0.1283^{* *}$ \\
& $(2.73)$ & $(2.52)$ \\
Segment cash flow/firm total cash flow & 0.0019 & 0.0019 \\
& $(1.30)$ & $(1.30)$ \\
Segment Tobin's q & -0.0090 & -0.0096 \\
& $(-0.75)$ & $(-0.79)$ \\
Segment compensation & 0.0005 & -0.0015 \\
& $(0.33)$ & $(-0.87)$ \\
Segment pay-for-performance sensitivity & $1.98 \mathrm{E}-05$ & $5.56 \mathrm{E}-06$ \\
& $(0.15)$ & $(0.04)$ \\
Restructuring dummy & & -0.0230 \\
& & $(-2.51)$ \\
Segment compensation * restructuring dummy & & $0.0043 *$ \\
Segment pay-for-performance sensitivity * & & $(1.84)$ \\
restructuring dummy & & $5.05 \mathrm{E}-05$ \\
$R^{2}$ & 0.91 & $(0.12)$ \\
Number of observations & 8921 & 0.91 \\
* indicates statistically significant at the 10\% level; ** at the 5\% level; *** at the 1\% level. & 8921 \\
\hline
\end{tabular}


Panel B. Sub-period 1997-1999

\begin{tabular}{lcc}
\hline \multicolumn{2}{c}{ Dependent variable: segment investment/firm total investment } & \\
\hline Independent Variable & Model $(1)$ & Model $(2)$ \\
Number of segments & $-0.0147^{* * *}$ & $-0.0180^{* * *}$ \\
& $(-3.90)$ & $(-3.86)$ \\
Segment assets/firm total assets & $0.2190^{* * *}$ & $0.2130^{* * *}$ \\
& $(3.69)$ & $(3.56)$ \\
Segment cash flow/firm total cash flow & $-0.0043^{* *}$ & $-0.0043^{* *}$ \\
& $(-2.05)$ & $(-2.07)$ \\
Segment Tobin's q & -0.0049 & -0.0073 \\
& $(-0.18)$ & $-0.27)$ \\
Segment compensation & $0.0025^{*}$ & 0.0013 \\
& $(1.86)$ & $0.69)$ \\
Segment pay-for-performance sensitivity & 0.0005 & 0.0007 \\
& $(0.85)$ & $(1.06)$ \\
Restructuring dummy & & -0.0104 \\
& & $(-1.07)$ \\
Segment compensation * restructuring dummy & & 0.0007 \\
& & $(0.23)$ \\
Segment pay-for-performance sensitivity * & & -0.0009 \\
restructuring dummy & & $(-0.55)$ \\
$R^{2}$ & 0.93 & 0.93 \\
Number of observations & 7206 & 7206 \\
\hline
\end{tabular}

Panel C. Sub-period 2000-2002

\begin{tabular}{lcc}
\hline \multicolumn{2}{c}{ Dependent variable: segment investment/firm total investment } & \\
\hline Independent Variable & \multicolumn{1}{c}{ Model $(1)$} & Model (2) \\
Number of segments & $-0.0409^{* * *}$ & $-0.0411^{* * *}$ \\
& $(-3.60)$ & $(-3.95)$ \\
Segment assets/firm total assets & -0.1361 & -0.1353 \\
& $(-0.73)$ & $(-0.76)$ \\
Segment cash flow/firm total cash flow & $0.0030^{*}$ & $0.0031^{*}$ \\
& $(1.93)$ & $(1.94)$ \\
Segment Tobin's q & -0.0065 & -0.0071 \\
& $(-0.95)$ & $(-0.98)$ \\
Segment compensation & $0.0029^{*}$ & 0.0002 \\
& $(1.95)$ & $(0.06)$ \\
Segment pay-for-performance sensitivity & 0.0007 & 0.0004 \\
& $(0.90)$ & $(1.06)$ \\
Restructuring dummy & & -0.0072 \\
& & $(-0.99)$ \\
Segment compensation * restructuring dummy & & $0.0046^{* *}$ \\
Segment pay-for-performance sensitivity * & & $(1.97)$ \\
restructuring dummy & & 0.0012 \\
$R^{2}$ & & $(0.65)$ \\
Number of observations & 0.74 & 0.74 \\
\hline
\end{tabular}

* indicates statistically significant at the $10 \%$ level; ** at the $5 \%$ level; *** at the $1 \%$ level. 
Table 7.9: Segment Investment, Industry Risk, and Option Grants-Alternative Industry Risk Measure

This table shows the coefficients from regressions of the size-adjusted ratio of segment investment as a fraction of the firm's total investment against number of segments, segment cash flow as a fraction of the firm's total cash flow, prior segment industry risk, and segment Tobin's q. The dependent variable is the ratio of segment investment as a fraction of the firm's total investment normalized by the ratio of segment assets as a fraction of the firm's total assets in the previous year (subtract the prior asset ratio and then divided by the same ratio). Segment industry risk is defined as the standard deviation of the asset-weighted monthly average stock returns for all single-segment firms in the industry for the 12 months prior to the firm's current fiscal year. Segment Tobin's q is the industry median q for all singlesegment firms in the industry in a year. All business segments are divided into 48 industries based on their SIC codes and the Fama and French 48-industry definition. I also include an option-grant dummy variable and its interaction with the segment return. The option-grant dummy equals to one when the segment is associated with a firm that has compensated its CEO with stock options in the previous year. Coefficients on segment fixed effects and constants are not reported. All t-statistics are based on the panel corrected standard errors (PCSEs), which adjust for autocorrelation and heteroskedasticity. Tstatistics are provided in parentheses.

\section{Dependent variable: size-adjusted segment investment/firm total investment}

\begin{tabular}{lc}
\hline Independent Variable & Estimate \\
Number of segments & $-0.6531^{* *}$ \\
& $(-2.15)$ \\
Segment cash flow/firm total cash flow & -0.0707 \\
& $(-0.97)$ \\
Segment industry risk & -3.3431 \\
& $(-1.24)$ \\
Option grant dummy * segment industry risk & $5.2775^{*}$ \\
& $(1.78)$ \\
Option grant dummy & -0.0950 \\
Segment Tobin's q & $(-0.37)$ \\
& -0.1960 \\
$R^{2}$ & $(-0.69)$ \\
Number of observations & 0.44 \\
\hline * indicates statistically significant at the $10 \%$ level; ** at the $5 \%$ level; *** at the $1 \%$ level. & 7657
\end{tabular}

Number of observations 


\section{Table 7.10: Segment Investment, Industry Risk, and Vega of Option Holdings}

This table shows the coefficients from regressions of the size-adjusted ratio of segment investment as a fraction of the firm's total investment against number of segments, segment cash flow as a fraction of the firm's total cash flow, prior segment industry risk, vega of option holdings, interaction between segment industry risk and vega, and segment Tobin's q. The dependent variable is the ratio of segment investment as a fraction of the firm's total investment normalized by the ratio of segment assets as a fraction of the firm's total assets in the previous year (subtract the prior asset ratio and then divided by the same ratio). Segment industry risk is defined as the standard deviation of the asset-weighted monthly average stock returns for all single-segment firms in the industry for the 24 months prior to the firm's current fiscal year. Option vega is the sensitivity of the option value with respect to a $100 \%$ change in stock price volatility. Segment Tobin's q is the industry median q for all single-segment firms in the industry in a year. All business segments are divided into 48 industries based on their SIC codes and the Fama and French 48-industry definition. Results base on panel regression with fixed effects for segments. Coefficients on segment fixed effects and constants are not reported. All t-statistics are based on the panel corrected standard errors (PCSEs), which adjust for autocorrelation and heteroskedasticity. $\mathrm{T}$-statistics are provided in parentheses.

\section{Dependent variable: size-adjusted segment investment/firm total investment}

\begin{tabular}{lc}
\hline Independent Variable & Estimate \\
Number of segments & $-0.6694^{* *}$ \\
& $(-2.17)$ \\
Segment cash flow/firm total cash flow & -0.0680 \\
& $(-0.91)$ \\
Segment industry risk & -1.3979 \\
& $(-0.91)$ \\
Vega of option holdings* segment industry risk & $1.57 \mathrm{E}-05$ \\
& $(0.99)$ \\
Vega of option holdings & $3.59 \mathrm{E}-07$ \\
Segment Tobin's q & $(0.22)$ \\
& -0.1809 \\
$R^{2}$ & $-0.65)$ \\
Number of observations & 0.44 \\
\hline
\end{tabular}

* indicates statistically significant at the $10 \%$ level; ** at the $5 \%$ level; *** at the $1 \%$ level. 


\section{Table 7.11: Firm Investment Risk and Compensation Characteristics with Discrete Governance Measures}

This table shows the coefficients from regressions of the ratio of a firm's investment in high-risk segments as a fraction of the firm's total investment against number of segments, CEO's option-grant sensitivity, option vega, stock ownership, the fraction of compensation in options, firm market leverage, firm's q and the weighted average q of its high-risk segments. Option-grant sensitivity is a measure of the dollar change in managerial options per $\$ 1,000$ change in shareholder wealth. Option vega is the sensitivity of the option value with respect to a $100 \%$ change in stock price volatility. I also include discrete governance indicator measures: governance-democracy equals to one if a firm's governance index is smaller than or equal to five; governance-dictatorship equals to one if a firm's governance index is greater than or equal to 14 . The governance index indicates the number of anti-takeover amendments in a firm's charter. Results base on panel regression with fixed effects for firms. Coefficients on firm fixed effects and constants are not reported. All t-statistics are based on the panel corrected standard errors (PCSEs), which adjust for autocorrelation and heteroskedasticity. T-statistics are provided in parentheses.

\begin{tabular}{|c|c|}
\hline \multicolumn{2}{|c|}{ Dependent variable: investment in high-risk segments/total investment } \\
\hline Independent Variable & Estimate \\
\hline Number of segments & $\begin{array}{l}-0.0038 \\
(-0.43)\end{array}$ \\
\hline Option sensitivity & $\begin{array}{c}0.0039 * * * \\
(2.63)\end{array}$ \\
\hline Option vega & $\begin{array}{c}3.64 \mathrm{E}-07 \\
(0.76)\end{array}$ \\
\hline CEO stock ownership & $\begin{array}{c}-0.0698 \\
(-0.38)\end{array}$ \\
\hline Fraction of compensation in options & $\begin{array}{c}-0.0606 \\
(-1.36)\end{array}$ \\
\hline Firm leverage & $\begin{array}{c}0.1456^{* *} \\
(2.01)\end{array}$ \\
\hline Firm Tobin's q & $\begin{array}{c}-0.0222 \\
(-1.04)\end{array}$ \\
\hline High-risk segments Tobin's q & $\begin{array}{c}0.2046^{* * *} \\
(16.25)\end{array}$ \\
\hline Governance-democracy & $\begin{array}{c}0.0595 * * * \\
(2.61)\end{array}$ \\
\hline Governance-dictatorship & $\begin{array}{c}-0.0641^{*} \\
(-1.65)\end{array}$ \\
\hline$R^{2}$ & 0.64 \\
\hline Number of observations & 2544 \\
\hline
\end{tabular}




\section{Table 7.12: Firm Investment Risk and Management Team’s Compensation Characteristics}

This table shows the coefficients from regressions of the ratio of a firm's investment in high-risk segments as a fraction of the firm's total investment against number of segments, top five executives' option-grant sensitivity, option vega, stock ownership, the fraction of compensation in options, firm market leverage, firm's q and the weighted average q of its high-risk segments. Option-grant sensitivity is a measure of the dollar change in managerial options per $\$ 1,000$ change in shareholder wealth. Option vega is the sensitivity of the option value with respect to a $100 \%$ change in stock price volatility. In Model (2) I include a governance index that indicates the number of anti-takeover amendments in a firm's charter. Results base on panel regression with fixed effects for firms. Coefficients on segment fixed effects and constants are not reported. All t-statistics are based on the panel corrected standard errors (PCSEs), which adjust for autocorrelation and heteroskedasticity. T-statistics are provided in parentheses.

\begin{tabular}{lcc}
\hline \multicolumn{3}{c}{ Dependent variable: investment in high-risk segments/total investment } \\
\hline Independent Variable & Model (1) & Model (2) \\
Number of segments & -0.0068 & -0.0041 \\
& $(-0.65)$ & $(-0.38)$ \\
Option sensitivity & $0.0028^{* * *}$ & $0.0034^{* * *}$ \\
& $(3.18)$ & $(2.95)$ \\
Option vega sensitivity & $-4.72 \mathrm{E}-08$ & $-2.25 \mathrm{E}-07$ \\
& $(-0.16)$ & $(-0.68)$ \\
Management team stock ownership & 0.1373 & -0.0129 \\
& $(1.45)$ & $(-0.14)$ \\
Fraction of compensation in options & -0.0572 & -0.0587 \\
& $(-1.38)$ & $(-1.29)$ \\
Firm leverage & 0.0560 & $0.1345^{*}$ \\
& $(0.84)$ & $(1.83)$ \\
Firm Tobin's q & $-0.0287 * *$ & -0.0234 \\
& $(-2.22)$ & $(-1.46)$ \\
High-risk segments Tobin's q & $0.1998^{* * *}$ & $0.1965^{* * *}$ \\
& $(11.48)$ & $(10.21)$ \\
Governance index & & $-0.0144^{*}$ \\
& & $(-1.89)$ \\
$R^{2}$ & 0.57 & 0.57 \\
Number of observations & 3040 & 2590 \\
\hline$*$ indicates statistically significant at the $10 \%$ level; ** at the $5 \%$ level; ***at the 1\% level.
\end{tabular}




\section{Table 8.1: Segment Investment, Industry Return, and Option Grants}

This table shows the coefficients from regressions of the size-adjusted ratio of segment investment as a fraction of the firm's total investment against number of segments, segment cash flow as a fraction of the firm's total cash flow, prior segment industry return, and segment Tobin's q. The dependent variable is the ratio of segment investment as a fraction of the firm's total investment normalized by the ratio of segment assets as a fraction of the firm's total assets in the previous year (subtract the prior asset ratio and then divided by the same ratio). Segment industry return is defined as the annualized assetweighted monthly average stock returns for all single-segment firms in the industry for the 12 months prior to the firm's current fiscal year. Segment Tobin's q is the industry median q for all single-segment firms in the industry in a year. All business segments are divided into 48 industries based on their SIC codes and the Fama and French 48-industry definition. I also include an option-grant dummy variable and its interaction with the segment return. The option-grant dummy equals to one when the segment is associated with a firm that has compensated its CEO with stock options in the previous year. Results base on panel regression with fixed effects for segments. Coefficients on segment fixed effects and constants are not reported. All t-statistics are based on the panel corrected standard errors (PCSEs), which adjust for autocorrelation and heteroskedasticity. T-statistics are provided in parentheses.

\begin{tabular}{lc}
\hline \multicolumn{2}{c}{ Dependent variable: size-adjusted segment investment/firm total investment } \\
\hline Independent Variable & Estimate \\
Number of segments & $-0.6452^{* *}$ \\
& $(-2.15)$ \\
Segment cash flow/firm total cash flow & -0.0737 \\
& $(-1.04)$ \\
Segment industry return & $-0.5372^{*}$ \\
& $(-1.69)$ \\
Option grant dummy * segment industry return & $0.7300^{* *}$ \\
& $(2.03)$ \\
Option grant dummy & 0.1406 \\
& $(0.71)$ \\
Segment Tobin's q & -0.1617 \\
& $(-0.54)$ \\
$R^{2}$ & 0.44 \\
Number of observations & 7657 \\
\hline * indicates statistically significant at the $10 \%$ level; ** at the 5\% level; *** at the 1\% level.
\end{tabular}

* indicates statistically significant at the $10 \%$ level; ** at the $5 \%$ level; *** at the $1 \%$ level. 


\section{Table 8.2: Segment Investment, Industry Return, and Stock Ownership}

This table shows the coefficients from regressions of the size-adjusted ratio of segment investment as a fraction of the firm's total investment against number of segments, segment cash flow as a fraction of the firm's total cash flow, prior segment industry return, and segment Tobin's q. The dependent variable is the ratio of segment investment as a fraction of the firm's total investment normalized by the ratio of segment assets as a fraction of the firm's total assets in the previous year (subtract the prior asset ratio and then divided by the same ratio). Segment industry return is defined as the annualized assetweighted monthly average stock returns for all single-segment firms in the industry for the 12 months prior to the firm's current fiscal year. Segment Tobin's q is the industry median q for all single-segment firms in the industry in a year. All business segments are divided into 48 industries based on their SIC codes and the Fama and French 48-industry definition. I also include CEO stock ownership and its interaction with the segment return. Stock ownership is defined as the number of shares owned by the CEO divided by the total number of shares outstanding at the beginning of the year. Results base on panel regression with fixed effects for segments. Coefficients on segment fixed effects and constants are not reported. All t-statistics are based on the panel corrected standard errors (PCSEs), which adjust for autocorrelation and heteroskedasticity. T-statistics are provided in parentheses.

\begin{tabular}{lc}
\hline \multicolumn{2}{c}{ Dependent variable: size-adjusted segment investment/firm total investment } \\
\hline Independent Variable & Estimate \\
Number of segments & $-0.6417^{* *}$ \\
& $(-2.14)$ \\
Segment cash flow/firm total cash flow & -0.0715 \\
& $(-1.00)$ \\
Segment industry return & 0.1493 \\
& $(1.37)$ \\
Stock ownership * segment industry return & $-8.4176^{* *}$ \\
& $(-2.23)$ \\
Stock ownership & 3.0022 \\
& $(1.37)$ \\
Segment Tobin's q & -0.1080 \\
& $(-0.37)$ \\
$R^{2}$ & \\
Number of observations & 0.44 \\
* indicates statistically significant at the $10 \%$ level; ** at the $5 \%$ level; *** at the 1\% level. & 7657 \\
\hline
\end{tabular}

* indicates statistically significant at the $10 \%$ level; ** at the $5 \%$ level; *** at the $1 \%$ level. 
Figure 1: Average CEO Compensation, Restructuring Sample vs. Market Sample

This figure depicts the averages of total direct compensations for CEOs in the restructuring sample and the market sample, respectively, two years after the restructurings.

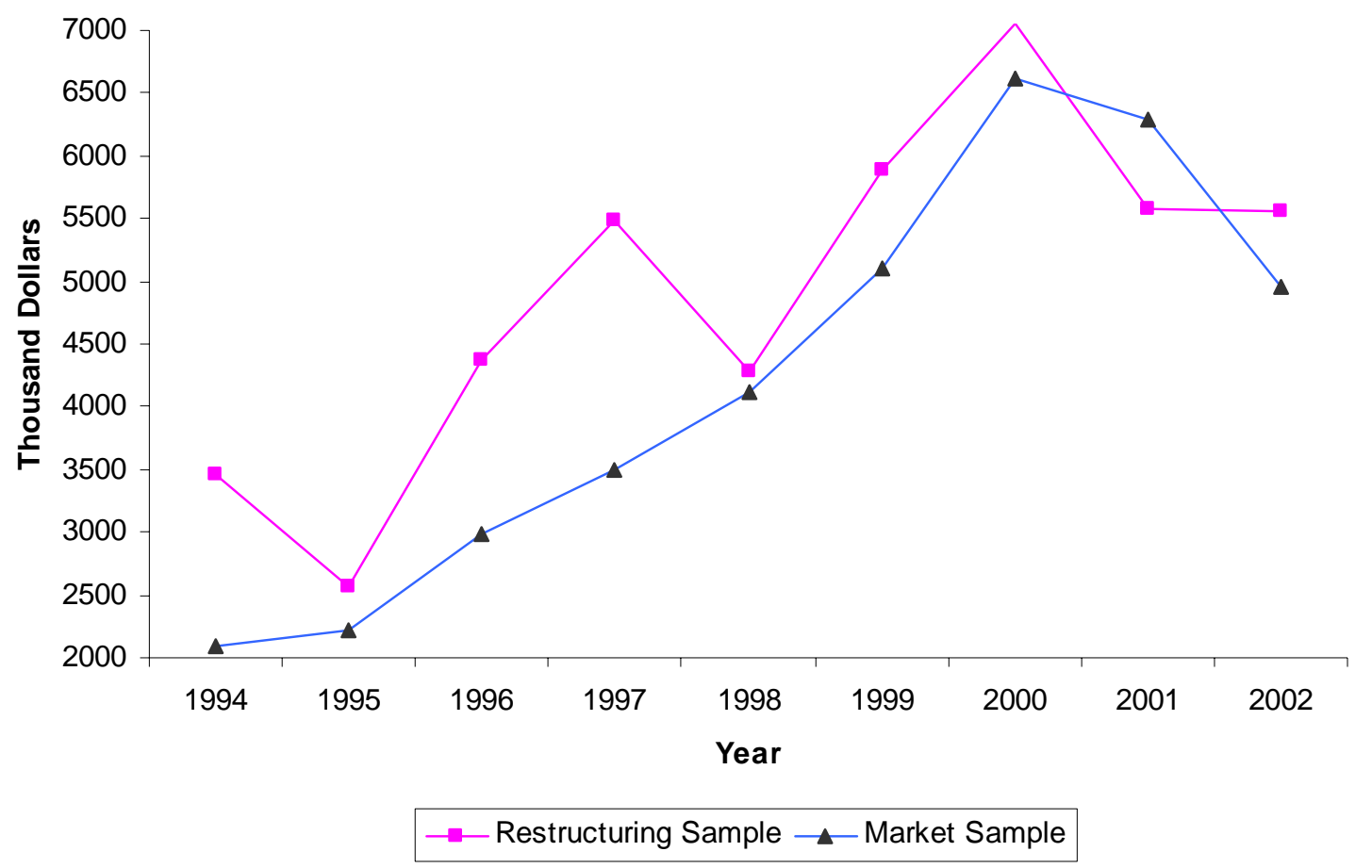


Figure 2: Average Percentage Change of CEO Compensation, Restructuring Sample vs. Market Sample

This figure depicts the averages of percentage changes of total direct compensations for CEOs in the restructuring sample and the market sample, respectively, two years after the restructurings.

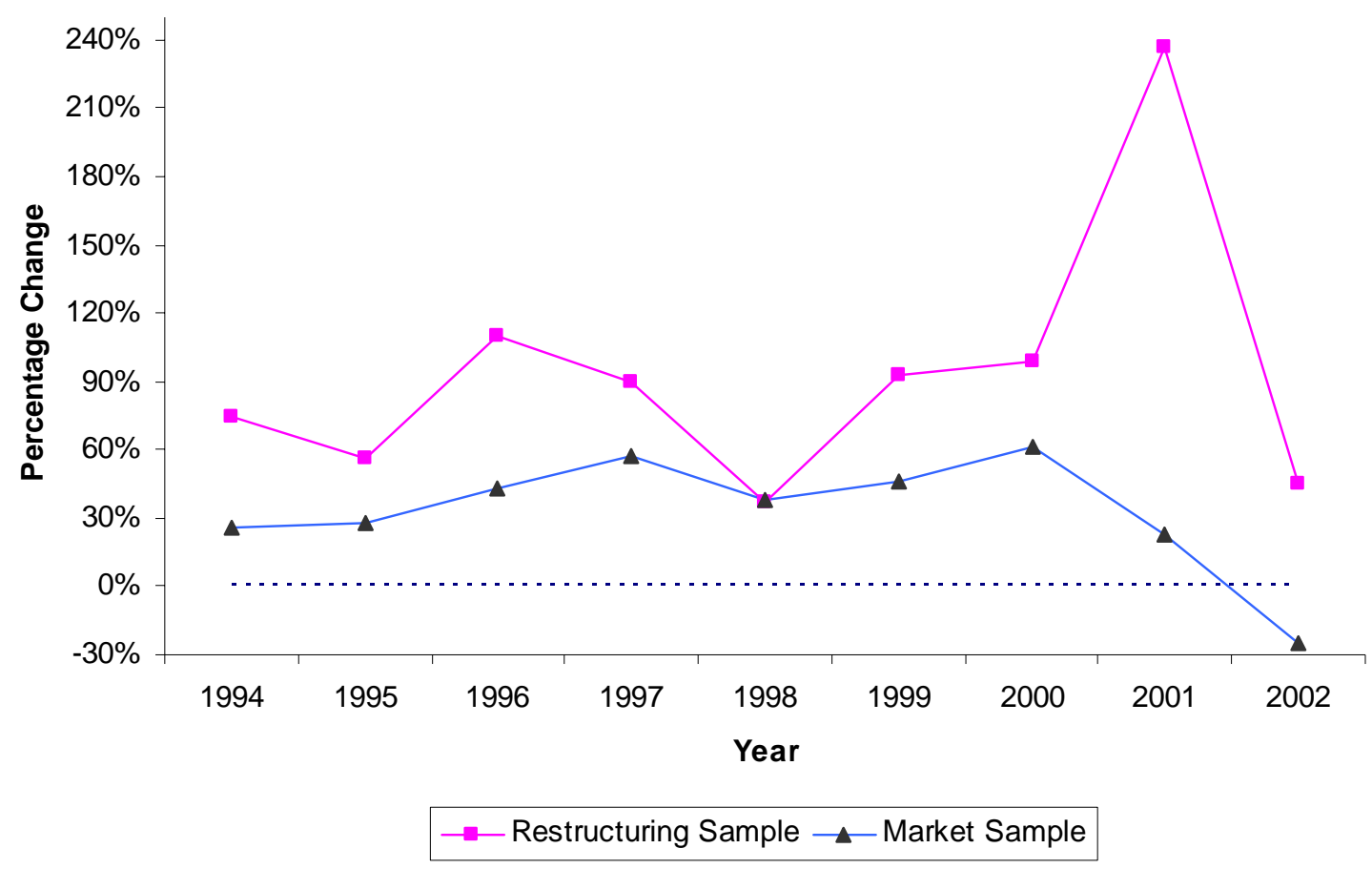




\section{APPENDIX: CORRELATION TABLES BY REGRESSION AND YEAR}

\section{Correlation 1}

This table describes the correlations among variables used in the compensation regressions of conglomerate CEOs' total direct compensation (\$000s) against conglomerates' synthetic compensation and its square. Tdc1 is the CEO's total direct compensation. Segtdc $1 \mathrm{f}$ is the predicted value from the industry's regression using the segment's actual sales figure. Segtdc1f 2 is the square of segtdc1f. Comps is the firm's total sales. Atdc $1 \mathrm{f}$ is the industry median total compensation for all single-segment CEOs in the industry. Atdc1f 2 is the square term of atdc1f2. Lncompa is the natural logarithm of the firm's total assets.

Panel A. Year 1994

\begin{tabular}{lrrrrrrr}
\hline \multicolumn{1}{c}{ Variable } & \multicolumn{1}{c}{ tdc1 } & \multicolumn{1}{c}{ segtdc1f } & segtdc1f2 & \multicolumn{1}{c}{ comps } & atdc1f & atdc1f2 & Incompa \\
\hline tdc1 & 1 & & & & & & \\
segtdc1f & 0.2150 & 1 & & & & & \\
segtdc1f2 & 0.1334 & 0.9233 & 1 & & & & \\
comps & 0.3165 & 0.4854 & 0.3695 & 1 & & & \\
atdc1f & 0.1882 & 0.1681 & 0.0476 & 0.1864 & 1 & & \\
atdc1f2 & 0.1689 & 0.1347 & 0.0362 & 0.1750 & 0.9698 & 1 & \\
lncompa & 0.4106 & 0.4936 & 0.3227 & 0.5498 & 0.1510 & 0.1456 & 1 \\
\hline
\end{tabular}

Panel B. Year 1998

\begin{tabular}{|c|c|c|c|c|c|c|c|}
\hline Variable & tdc1 & segtdc1f & segtdc1f2 & comps & atdc1f & atdc1f2 & lncompa \\
\hline $\operatorname{tdc} 1$ & 1 & & & & & & \\
\hline segtdc1f & 0.1531 & 1 & & & & & \\
\hline segtdc1f2 & 0.0455 & 0.8730 & 1 & & & & \\
\hline comps & 0.2839 & 0.4095 & 0.2091 & 1 & & & \\
\hline atdc $1 \mathrm{f}$ & 0.1204 & 0.0188 & -0.0231 & 0.2119 & 1 & & \\
\hline atdc $1 \mathrm{f} 2$ & 0.1117 & 0.0324 & -0.0168 & 0.2276 & 0.9566 & 1 & \\
\hline lncompa & 0.3334 & 0.3093 & 0.1275 & 0.5486 & 0.2256 & 0.2269 & 1 \\
\hline
\end{tabular}

Panel C. Year 2002

\begin{tabular}{|c|c|c|c|c|c|c|c|}
\hline Variable & tdc 1 & segtdclf & segtdc1f2 & comps & atdc1f & atdc $1 \mathrm{f} 2$ & lncompa \\
\hline $\operatorname{tdc} 1$ & 1 & & & & & & \\
\hline segtdc1f & 0.2587 & 1 & & & & & \\
\hline segtdc1f2 & 0.1523 & 0.8883 & 1 & & & & \\
\hline comps & 0.4150 & 0.7199 & 0.6378 & 1 & & & \\
\hline atdc1f & 0.1617 & 0.1414 & 0.1212 & 0.1529 & 1 & & \\
\hline $\operatorname{atdc} 1 \mathrm{f} 2$ & 0.1394 & 0.1889 & 0.1489 & 0.1558 & 0.9625 & 1 & \\
\hline Incompa & 0.4844 & 0.4016 & 0.2230 & 0.5816 & 0.1144 & 0.1368 & 1 \\
\hline
\end{tabular}




\section{Correlation 2}

This table describes the correlations among variables used in the regressions of the ratio of segment investment as a fraction of the firm's total investment on compensation levels. Cc is the ratio of segment investment as a fraction of the firm's total investment. Count is the number of segments in a firm. Aa is segment asset as a fraction of firm total asset. Cfcf is segment cash flow as a fraction of firm total cash flow. Medindq is the industry median q for all singlesegment firms in the industry in a year. Segtdc 1 is the synthetic segment compensation divided by the market average compensation. Sentdc 1 is defined as the pay-for-performance sensitivity of all stand alone firms in the segment's industry in a particular year. It is estimated from a cross-sectional regression of change in executive total compensation on change in shareholder wealth. S1 tdc1 is the interaction between segtdc1 and s1, where s1 is the restructuring dummy. The restructuring dummy equals to one when the segment is associated with a firm that has changed its reported segments by either adding a new segment or dropping an existing segment. S1_sen is the interaction between sentdc1 and s1. D is the slope coefficient from the industry compensation regression. S1_d is the interaction between $\mathrm{d}$ and $\mathrm{s1}$. Ceochg is the CEO change indicator. It equals to one when the firm has changed its CEO in the previous year. Tech is an indicator variable for tech segments-segments with SIC code 737. Avgq1 the industry average R\&D/Sales for stand-alone firms. Avgq2 is the industry average capital expenditures over net property, plant, and equipment for stand-alone firms.

Panel A. Year 1994

\begin{tabular}{|c|c|c|c|c|c|c|c|c|c|c|c|c|c|c|c|c|}
\hline Variable & $\mathrm{cc}$ & count & aa & cfcf & medindq & segtdc1 & sentdc1 & s1 tdc1 & s1_sen & s1 & $\mathrm{d}$ & s1_d & ceochg & tech & avgq1 & $\operatorname{avgq} 2$ \\
\hline $\mathrm{cc}$ & 1 & & & & & & & & & & & & & & & \\
\hline count & -0.334 & 1 & & & & & & & & & & & & & & \\
\hline aa & 0.724 & -0.383 & 1 & & & & & & & & & & & & & \\
\hline $\operatorname{cfcf}$ & 0.186 & -0.080 & 0.189 & 1 & & & & & & & & & & & & \\
\hline medindq & 0.032 & -0.045 & 0.008 & 0.004 & 1 & & & & & & & & & & & \\
\hline segtdc1 & 0.030 & 0.064 & 0.033 & 0.011 & 0.060 & 1 & & & & & & & & & & \\
\hline sentdc1 & 0.007 & -0.030 & -0.007 & 0.006 & 0.048 & -0.038 & 1 & & & & & & & & & \\
\hline s1_tdc1 & -0.057 & 0.076 & -0.061 & -0.004 & 0.031 & 0.189 & -0.021 & 1 & & & & & & & & \\
\hline s1_sen & -0.020 & -0.018 & -0.026 & 0.001 & 0.024 & -0.037 & 0.469 & 0.033 & 1 & & & & & & & \\
\hline $\mathrm{s} 1$ & -0.076 & 0.051 & -0.100 & -0.014 & 0.002 & -0.002 & 0.025 & 0.757 & 0.151 & 1 & & & & & & \\
\hline d & 0.013 & -0.019 & -0.012 & 0.027 & -0.082 & -0.020 & 0.306 & -0.019 & 0.140 & 0.014 & 1 & & & & & \\
\hline s1_d & -0.058 & 0.035 & -0.066 & 0.001 & -0.054 & -0.027 & 0.139 & 0.342 & 0.344 & 0.527 & 0.383 & 1 & & & & \\
\hline ceochg & -0.014 & 0.035 & -0.017 & -0.014 & 0.018 & 0.024 & 0.018 & 0.009 & -0.016 & 0.027 & 0.015 & 0.005 & 1 & & & \\
\hline tech & -0.025 & -0.041 & -0.028 & -0.011 & 0.154 & 0.012 & -0.016 & 0.022 & -0.007 & 0.012 & -0.059 & -0.019 & 0.057 & 1 & & \\
\hline avgq1 & 0.013 & -0.042 & 0.025 & 0.012 & 0.640 & -0.015 & -0.046 & -0.003 & -0.021 & -0.021 & 0.003 & -0.015 & 0.007 & 0.001 & 1 & \\
\hline $\operatorname{avgq} 2$ & -0.091 & 0.005 & -0.012 & -0.004 & -0.020 & 0.311 & -0.024 & 0.148 & -0.012 & 0.013 & -0.149 & -0.053 & -0.027 & 0.036 & 0.013 & 1 \\
\hline
\end{tabular}


Panel B. Year 1998

\begin{tabular}{|c|c|c|c|c|c|c|c|c|c|c|c|c|c|c|c|c|}
\hline Variable & $\mathrm{cc}$ & count & aa & cfcf & medindq & segtdc1 & sentdc1 & s1_tdc1 & s1_sen & $\mathrm{s} 1$ & $\mathrm{~d}$ & s1_d & ceochg & tech & avgq1 & $\operatorname{avgq} 2$ \\
\hline $\mathrm{cc}$ & 1 & & & & & & & & & & & & & & & \\
\hline count & -0.339 & 1 & & & & & & & & & & & & & & \\
\hline aa & 0.728 & -0.391 & 1 & & & & & & & & & & & & & \\
\hline $\operatorname{cfcf}$ & 0.045 & -0.049 & 0.069 & 1 & & & & & & & & & & & & \\
\hline medindq & 0.019 & -0.029 & -0.027 & 0.007 & 1 & & & & & & & & & & & \\
\hline segtdc1 & 0.008 & 0.064 & 0.011 & -0.001 & 0.034 & 1 & & & & & & & & & & \\
\hline sentdc1 & 0.034 & -0.023 & 0.013 & 0.000 & -0.051 & 0.297 & 1 & & & & & & & & & \\
\hline s1_tdc1 & -0.029 & -0.015 & -0.036 & -0.003 & 0.005 & 0.329 & 0.049 & 1 & & & & & & & & \\
\hline s1_sen & -0.008 & -0.034 & -0.040 & -0.007 & -0.028 & 0.067 & 0.440 & 0.245 & 1 & & & & & & & \\
\hline $\mathrm{s} 1$ & -0.082 & -0.054 & -0.112 & -0.014 & -0.065 & 0.004 & -0.053 & 0.474 & 0.183 & 1 & & & & & & \\
\hline$d$ & -0.018 & -0.016 & -0.007 & 0.020 & 0.225 & 0.269 & 0.619 & 0.047 & 0.216 & -0.059 & 1 & & & & & \\
\hline s1_d & -0.047 & -0.031 & -0.077 & -0.013 & 0.092 & 0.064 & 0.181 & 0.370 & 0.529 & 0.471 & 0.371 & 1 & & & & \\
\hline ceochg & 0.001 & -0.031 & 0.009 & 0.008 & 0.001 & 0.019 & -0.067 & -0.010 & -0.034 & -0.020 & 0.046 & 0.016 & 1 & & & \\
\hline tech & -0.038 & -0.006 & -0.041 & 0.045 & 0.298 & -0.010 & -0.016 & -0.017 & -0.003 & -0.011 & 0.119 & 0.067 & 0.041 & 1 & & \\
\hline avgq1 & 0.032 & -0.066 & 0.022 & 0.004 & 0.580 & -0.012 & -0.009 & -0.039 & -0.001 & -0.057 & 0.102 & 0.034 & -0.043 & 0.068 & 1 & \\
\hline $\operatorname{avgq} 2$ & -0.034 & 0.064 & -0.025 & -0.004 & 0.096 & 0.010 & -0.035 & 0.000 & -0.026 & 0.003 & 0.017 & 0.003 & 0.065 & 0.048 & 0.062 & 1 \\
\hline
\end{tabular}




\section{Panel C. Year 2002}

\begin{tabular}{|c|c|c|c|c|c|c|c|c|c|c|c|c|c|c|c|c|}
\hline Variable & $\mathrm{cc}$ & count & aa & $\mathrm{cfcf}$ & medindq & segtdc1 & sentdc1 & s1 tdc1 & s1_sen & s1 & $\mathrm{d}$ & s1_d & ceochg & tech & avgq1 & $\operatorname{avgq2}$ \\
\hline $\mathrm{cc}$ & 1 & & & & & & & & & & & & & & & \\
\hline count & -0.194 & 1 & & & & & & & & & & & & & & \\
\hline aa & 0.407 & -0.376 & 1 & & & & & & & & & & & & & \\
\hline $\operatorname{cfcf}$ & 0.104 & -0.102 & 0.224 & 1 & & & & & & & & & & & & \\
\hline medindq & -0.008 & 0.016 & -0.017 & -0.012 & 1 & & & & & & & & & & & \\
\hline segtdc1 & 0.019 & 0.113 & 0.011 & 0.002 & 0.115 & 1 & & & & & & & & & & \\
\hline sentdc 1 & 0.064 & -0.066 & 0.000 & -0.003 & -0.128 & -0.028 & 1 & & & & & & & & & \\
\hline $\mathrm{s} 1 \_\mathrm{tdc} 1$ & 0.013 & 0.108 & -0.032 & -0.012 & 0.027 & 0.738 & -0.025 & 1 & & & & & & & & \\
\hline s1_sen & 0.101 & -0.014 & -0.026 & -0.023 & -0.046 & -0.020 & 0.476 & 0.001 & 1 & & & & & & & \\
\hline s1 & -0.030 & 0.049 & -0.130 & -0.035 & 0.012 & 0.018 & -0.045 & 0.248 & 0.118 & 1 & & & & & & \\
\hline d & -0.009 & -0.024 & 0.018 & 0.009 & 0.154 & 0.242 & -0.110 & 0.122 & -0.033 & -0.006 & 1 & & & & & \\
\hline sl_d & 0.003 & 0.011 & -0.062 & -0.001 & 0.057 & 0.183 & -0.051 & 0.348 & 0.004 & 0.509 & 0.410 & 1 & & & & \\
\hline ceochg & -0.004 & 0.087 & -0.019 & -0.007 & 0.053 & 0.074 & -0.077 & 0.099 & -0.070 & 0.082 & -0.044 & 0.017 & 1 & & & \\
\hline tech & -0.023 & -0.051 & -0.059 & -0.003 & 0.154 & 0.152 & -0.043 & 0.043 & -0.009 & 0.002 & 0.216 & 0.087 & -0.039 & 1 & & \\
\hline avgq1 & -0.001 & 0.059 & -0.014 & 0.010 & 0.587 & 0.045 & 0.070 & 0.011 & 0.018 & 0.012 & -0.020 & -0.005 & 0.005 & 0.040 & 1 & \\
\hline $\operatorname{avgq} 2$ & 0.013 & -0.045 & 0.012 & 0.000 & 0.068 & 0.023 & 0.068 & 0.005 & 0.051 & 0.006 & -0.061 & -0.022 & 0.065 & 0.000 & -0.017 & 1 \\
\hline
\end{tabular}




\section{Correlation 3}

This table describes the correlations among variables used in the regressions of the size-adjusted ratio of segment investment as a fraction of the firm's total investment against industry risk and return. Excapx is the ratio of segment investment as a fraction of the firm's total investment normalized by the ratio of segment assets as a fraction of the firm's total assets in the previous year (subtract the prior asset ratio and then divided by the same ratio). Count is the number of segments. Cfcf is segment cash flow as a fraction of the firm's cash flow. Vol2 is segment industry risk. It is defined as the standard deviation of the assetweighted monthly average stock returns for all single-segment firms in the industry for the 24 months prior to the firm's current fiscal year. Op is the optiongrant dummy. It equals to one when the segment is associated with a firm that has compensated its CEO with stock options in the previous year. Op_vol2 is the interaction between op and vol2. Hldvega is vega of option holdings. Option vega is the sensitivity of the option value with respect to a $100 \%$ change in stock price volatility. Hldvega vol2 is the interaction between hldvega and vol2. Lagq is the industry median q for all single-segment firms in the industry in a year. Voll is defined as the standard deviation of the asset-weighted monthly average stock returns for all single-segment firms in the industry for the 12 months prior to the firm's current fiscal year. Op_voll is the interaction between op and voll. Ret is defined as the annualized asset-weighted monthly average stock returns for all single-segment firms in the industry for the 12 months prior to the firm's current fiscal year. Op_ret is the interaction between op and ret. Lceoown is defined as the number of shares owned by the CEO divided by the total number of shares outstanding at the beginning of the year. Own_ret is the interaction between lceoown and ret.

Panel A. Year 1994

\begin{tabular}{|c|c|c|c|c|c|c|c|c|c|c|c|c|c|c|c|}
\hline Variable & excapx & count & $\mathrm{cfcf}$ & vol2 & op_vol2 & op & hldvega_vol2 & hldvega & lagq & vol1 & op_vol1 & ret & op_ret & own_ret & lceoown \\
\hline excapx & 1 & & & & & & & & & & & & & & \\
\hline count & 0.045 & 1 & & & & & & & & & & & & & \\
\hline $\operatorname{cfcf}$ & -0.016 & -0.067 & 1 & & & & & & & & & & & & \\
\hline vol2 & 0.002 & -0.008 & 0.017 & 1 & & & & & & & & & & & \\
\hline op_vol2 & -0.095 & 0.121 & -0.076 & 0.430 & 1 & & & & & & & & & & \\
\hline op & -0.093 & 0.113 & -0.034 & -0.007 & 0.844 & 1 & & & & & & & & & \\
\hline hldvega_vol2 & -0.037 & 0.284 & -0.058 & 0.115 & 0.390 & 0.370 & 1 & & & & & & & & \\
\hline hldvega & -0.034 & 0.275 & -0.047 & -0.033 & 0.313 & 0.395 & 0.949 & 1 & & & & & & & \\
\hline lagq & 0.040 & -0.044 & 0.009 & -0.024 & 0.025 & 0.043 & 0.119 & 0.124 & 1 & & & & & & \\
\hline voll & 0.007 & 0.002 & -0.009 & 0.657 & 0.249 & -0.041 & 0.115 & 0.003 & 0.105 & 1 & & & & & \\
\hline op_vol1 & -0.092 & 0.121 & -0.070 & 0.283 & 0.898 & 0.838 & 0.397 & 0.344 & 0.086 & 0.409 & 1 & & & & \\
\hline ret & -0.022 & -0.007 & -0.015 & -0.044 & -0.011 & 0.017 & -0.029 & -0.019 & 0.151 & 0.118 & 0.085 & 1 & & & \\
\hline op_ret & -0.032 & 0.053 & -0.076 & -0.043 & 0.358 & 0.455 & 0.131 & 0.153 & 0.137 & 0.094 & 0.457 & 0.757 & 1 & & \\
\hline own_ret & 0.057 & 0.030 & -0.035 & 0.026 & -0.093 & -0.139 & -0.105 & -0.110 & 0.021 & 0.047 & -0.100 & 0.271 & 0.053 & 1 & \\
\hline lceoown & 0.230 & 0.068 & -0.012 & 0.073 & -0.137 & -0.206 & -0.154 & -0.168 & -0.003 & 0.045 & -0.159 & -0.006 & -0.107 & 0.670 & 1 \\
\hline
\end{tabular}


Panel B. Year 1998

\begin{tabular}{|c|c|c|c|c|c|c|c|c|c|c|c|c|c|c|c|}
\hline Variable & excapx & count & cfcf & vol2 & op_vol2 & op & hldvega_vol2 & hldvega & lagq & vol1 & op_vol1 & ret & op_ret & own_ret & lceoown \\
\hline excapx & 1 & & & & & & & & & & & & & & \\
\hline count & 0.057 & 1 & & & & & & & & & & & & & \\
\hline $\operatorname{cfcf}$ & -0.009 & -0.041 & 1 & & & & & & & & & & & & \\
\hline vol2 & -0.002 & -0.004 & -0.006 & 1 & & & & & & & & & & & \\
\hline op_vol2 & -0.084 & 0.005 & 0.034 & 0.600 & 1 & & & & & & & & & & \\
\hline op & -0.112 & 0.034 & -0.020 & 0.020 & 0.737 & 1 & & & & & & & & & \\
\hline hldvega_vol2 & -0.020 & 0.252 & -0.057 & 0.255 & 0.381 & 0.252 & 1 & & & & & & & & \\
\hline hldvega & -0.019 & 0.275 & -0.050 & 0.055 & 0.236 & 0.269 & 0.925 & 1 & & & & & & & \\
\hline lagq & 0.056 & -0.052 & 0.012 & 0.333 & 0.236 & 0.041 & 0.199 & 0.137 & 1 & & & & & & \\
\hline voll & 0.002 & -0.011 & -0.001 & 0.785 & 0.498 & 0.043 & 0.200 & 0.066 & 0.325 & 1 & & & & & \\
\hline op_vol1 & -0.090 & 0.010 & 0.033 & 0.455 & 0.902 & 0.759 & 0.330 & 0.244 & 0.222 & 0.611 & 1 & & & & \\
\hline ret & 0.003 & -0.017 & -0.050 & -0.302 & -0.238 & -0.052 & -0.151 & -0.089 & -0.144 & -0.416 & -0.318 & 1 & & & \\
\hline op_ret & 0.001 & -0.013 & -0.088 & -0.262 & 0.074 & 0.384 & -0.048 & 0.025 & -0.134 & -0.383 & -0.001 & 0.792 & 1 & & \\
\hline own_ret & 0.337 & 0.134 & -0.052 & -0.041 & -0.178 & -0.200 & -0.079 & -0.082 & 0.008 & -0.088 & -0.209 & 0.283 & 0.060 & 1 & \\
\hline lceoown & 0.307 & 0.117 & -0.019 & 0.042 & -0.181 & -0.272 & -0.106 & -0.120 & 0.041 & -0.001 & -0.190 & -0.011 & -0.132 & 0.579 & 1 \\
\hline
\end{tabular}


Panel C. Year 2002

\begin{tabular}{|c|c|c|c|c|c|c|c|c|c|c|c|c|c|c|c|}
\hline Variable & excapx & count & cfcf & vol2 & op_vol2 & op & hldvega_vol2 & hldvega & lagq & vol1 & op_vol1 & ret & op_ret & own_ret & lceoown \\
\hline excapx & 1 & & & & & & & & & & & & & & \\
\hline count & 0.013 & 1 & & & & & & & & & & & & & \\
\hline cfcf & -0.012 & -0.088 & 1 & & & & & & & & & & & & \\
\hline vol2 & 0.011 & 0.001 & -0.047 & 1 & & & & & & & & & & & \\
\hline op_vol2 & 0.005 & -0.226 & 0.047 & 0.497 & 1 & & & & & & & & & & \\
\hline op & -0.039 & -0.358 & 0.041 & -0.096 & 0.766 & 1 & & & & & & & & & \\
\hline hldvega_vol2 & -0.008 & 0.017 & -0.011 & 0.158 & 0.266 & 0.181 & 1 & & & & & & & & \\
\hline hldvega & -0.017 & -0.002 & -0.010 & 0.036 & 0.197 & 0.204 & 0.948 & 1 & & & & & & & \\
\hline lagq & -0.009 & -0.032 & -0.035 & 0.444 & 0.194 & -0.078 & 0.102 & 0.055 & 1 & & & & & & \\
\hline voll & 0.028 & 0.011 & -0.034 & 0.889 & 0.421 & -0.111 & 0.119 & 0.012 & 0.316 & 1 & & & & & \\
\hline op_vol1 & -0.006 & -0.214 & 0.036 & 0.473 & 0.947 & 0.724 & 0.239 & 0.175 & 0.163 & 0.533 & 1 & & & & \\
\hline ret & -0.058 & 0.076 & -0.044 & -0.203 & -0.096 & -0.028 & -0.071 & -0.041 & -0.017 & -0.169 & -0.079 & 1 & & & \\
\hline op_ret & -0.087 & -0.060 & -0.035 & -0.127 & 0.000 & 0.109 & -0.054 & -0.017 & 0.023 & -0.098 & 0.013 & 0.874 & 1 & & \\
\hline own_ret & 0.053 & 0.140 & -0.052 & -0.060 & -0.078 & -0.087 & -0.011 & -0.007 & 0.048 & -0.027 & -0.078 & 0.314 & 0.081 & 1 & \\
\hline lceoown & 0.076 & 0.254 & -0.022 & 0.047 & -0.252 & -0.341 & -0.085 & -0.098 & 0.108 & 0.033 & -0.252 & 0.004 & -0.042 & 0.184 & 1 \\
\hline
\end{tabular}




\section{Correlation 4}

This table describes the correlations among variables used in the regressions of the ratio of a firm's investment in high-risk segments as a fraction of the firm's total investment against compensation characteristics. Ccroag is a firm's investment in high-risk segments as a fraction of the firm's total investment. Count is the number of segments. Opsen is the CEO's option-grant sensitivity. Option-grant sensitivity is a measure of the dollar change in managerial options per $\$ 1,000$ change in shareholder wealth. Vega is the sensitivity of the option value with respect to a $100 \%$ change in stock price volatility. Lceoown is defined as the number of shares owned by the CEO divided by the total number of shares outstanding at the beginning of the year. Lblkshr is the fraction of compensation in options. Mdebt is a firm's market leverage. Q is the firm's q. Avgq is the weighted average q of its high-risk segments. Gindex indicates the number of antitakeover amendments in a firm's charter. Demo equals to one if a firm's governance index is smaller than or equal to five. Dictor equals to one if a firm's governance index is greater than or equal to 14 .

Panel A. Year 1994

\begin{tabular}{|c|c|c|c|c|c|c|c|c|c|c|c|c|}
\hline Variable & ccroag & count & opsen & vega & lceoown & lblkshr & mdebt & $q$ & avgq & gindex & demo & dictor \\
\hline ccroag & 1 & & & & & & & & & & & \\
\hline count & 0.027 & 1 & & & & & & & & & & \\
\hline opsen & 0.030 & 0.069 & 1 & & & & & & & & & \\
\hline vega & 0.088 & 0.154 & 0.451 & 1 & & & & & & & & \\
\hline lceoown & -0.078 & 0.031 & 0.040 & -0.084 & 1 & & & & & & & \\
\hline lblkshr & 0.115 & 0.122 & 0.569 & 0.552 & -0.123 & 1 & & & & & & \\
\hline mdebt & -0.112 & 0.191 & 0.010 & 0.119 & -0.135 & -0.036 & 1 & & & & & \\
\hline$q$ & 0.044 & -0.111 & -0.007 & -0.032 & 0.095 & 0.045 & -0.619 & 1 & & & & \\
\hline avgq & 0.550 & 0.168 & 0.011 & 0.033 & -0.153 & 0.130 & -0.079 & 0.073 & 1 & & & \\
\hline gindex & 0.027 & -0.016 & -0.054 & -0.011 & -0.232 & -0.025 & 0.052 & -0.075 & 0.023 & 1 & & \\
\hline demo & 0.062 & -0.083 & 0.107 & -0.082 & 0.261 & 0.020 & -0.095 & 0.165 & 0.110 & -0.557 & 1 & \\
\hline dictor & -0.023 & -0.002 & -0.040 & -0.043 & -0.023 & -0.001 & 0.050 & -0.068 & 0.044 & 0.515 & -0.142 & 1 \\
\hline
\end{tabular}


Panel B. Year 1998

\begin{tabular}{|c|c|c|c|c|c|c|c|c|c|c|c|c|}
\hline Variable & ccroag & count & opsen & vega & lceoown & lblkshr & mdebt & $q$ & avgq & gindex & demo & dictor \\
\hline ccroag & 1 & & & & & & & & & & & \\
\hline count & 0.005 & 1 & & & & & & & & & & \\
\hline opsen & 0.088 & -0.049 & 1 & & & & & & & & & \\
\hline vega & 0.136 & 0.197 & 0.426 & 1 & & & & & & & & \\
\hline lceoown & 0.028 & 0.033 & 0.000 & -0.087 & 1 & & & & & & & \\
\hline lblkshr & 0.142 & 0.098 & 0.486 & 0.533 & -0.145 & 1 & & & & & & \\
\hline mdebt & -0.073 & 0.122 & -0.114 & -0.085 & -0.073 & -0.096 & 1 & & & & & \\
\hline$q$ & 0.169 & -0.052 & 0.128 & 0.159 & 0.046 & 0.139 & -0.639 & 1 & & & & \\
\hline avgq & 0.660 & 0.191 & 0.018 & 0.169 & 0.014 & 0.142 & -0.109 & 0.208 & 1 & & & \\
\hline gindex & -0.063 & -0.048 & 0.000 & -0.031 & -0.277 & 0.055 & 0.041 & -0.001 & -0.147 & 1 & & \\
\hline demo & 0.071 & -0.127 & 0.118 & -0.101 & 0.166 & -0.029 & -0.100 & 0.063 & 0.077 & -0.551 & 1 & \\
\hline dictor & -0.075 & 0.055 & -0.013 & -0.049 & -0.085 & -0.005 & 0.045 & -0.062 & -0.106 & 0.511 & -0.161 & 1 \\
\hline
\end{tabular}


Panel C. Year 2002

\begin{tabular}{|c|c|c|c|c|c|c|c|c|c|c|c|c|}
\hline Variable & ccroag & count & opsen & vega & lceoown & lblkshr & mdebt & $q$ & avgq & gindex & demo & dictor \\
\hline ccroag & 1 & & & & & & & & & & & \\
\hline count & -0.094 & 1 & & & & & & & & & & \\
\hline opsen & -0.041 & -0.027 & 1 & & & & & & & & & \\
\hline vega & -0.063 & 0.076 & 0.106 & 1 & & & & & & & & \\
\hline lceoown & 0.138 & 0.170 & -0.048 & -0.099 & 1 & & & & & & & \\
\hline lblkshr & -0.046 & -0.113 & 0.389 & 0.494 & -0.205 & 1 & & & & & & \\
\hline mdebt & -0.074 & 0.109 & -0.120 & -0.131 & -0.083 & -0.187 & 1 & & & & & \\
\hline$q$ & 0.134 & -0.065 & 0.092 & 0.178 & -0.012 & 0.177 & -0.636 & 1 & & & & \\
\hline avgq & 0.479 & 0.070 & 0.073 & 0.034 & 0.069 & 0.049 & -0.083 & 0.105 & 1 & & & \\
\hline gindex & -0.035 & -0.070 & 0.035 & 0.046 & -0.156 & 0.147 & 0.087 & -0.022 & -0.040 & 1 & & \\
\hline demo & 0.033 & -0.151 & 0.176 & -0.053 & -0.060 & 0.028 & -0.235 & 0.029 & -0.004 & -0.427 & 1 & \\
\hline dictor & -0.085 & 0.067 & 0.039 & -0.014 & -0.044 & 0.063 & 0.086 & -0.077 & -0.063 & 0.567 & -0.126 & 1 \\
\hline
\end{tabular}




\section{References}

Aggarwal, R. K., and A. A. Samwick, 1999, The other side of the trade-off: The impact of risk on executive compensation, Journal of Political Economy 107, 65-105.

Almazan, Andres, Jay C. Hartzell, and Laura T. Starks, 2003, Active institutional shareholders and managerial compensation, Working Paper, University of Texas.

Anderson, R. C., T. W. Bates, J. M. Bizjak, and M. L. Lemmon, 2000, Corporate governance and firm diversification, Financial Management 29, 5-22.

Baker, G., M. Jensen and K. Murphy, 1988, Compensation and incentives: practice vs. theory, Journal of Finance 43, 593-616.

Berger, Philip G., and Eli Ofek, 1995, Diversification's effect on firm value, Journal of Financial Economics 37, 39-65.

Billett, M., and D. Mauer, 2003, Cross subsidies, external financing constraints, and the contribution of the internal capital market to firm value, Review of Financial Studies 16, 1167-1201.

Bizjak, J., M. L. Lemmon and L. Naven, 2000, Has the use of peer groups contributed to higher levels of executive compensation?, Working Paper.

Black, F., and M. Scholes, 1973, The pricing of options and corporate liabilities, Journal of Political Economy 81, 637-654.

Chevalier, J. A., 2004, What do we know about cross-subsidization? Evidence from merging firms, Advances in Economic Analysis \& Policy 4, Article 3.

Cochrane, J. H., 2002, Stocks as money: convenience yield and the tech-stock bubble, Working Paper

Cohen, R. B. , B. J. Hall, and L. M. Viceria, 2000, Do executive stock options encourage risk-taking?, Working Paper, Harvard Business School.

Coles, J. L. , N. D. Daniel, and L. Naveen, 2003, Executive compensation and managerial risk-taking, Working Paper.

Core, John, and Wayne Guay, 1999, The use of equity grants to manage optimal equity incentive levels, Journal of Accounting \& Economics 28, 151-184.

Core, John, and Wayne Guay, 2002, Estimating the value of employee stock option portfolios and their sensitivities to price and volatility, Journal of Accounting Research 40, 613-630.

Core, J.E., R.W. Holthausen, and D.F., Larker, 1999. Corporate governance, chief executive officer compensation, and firm performance, Journal of Financial Economics 51, 371-406.

Daniel, N. D., J. S. Martin, and L. Naveen, 2003, The hidden cost of managerial incentives: evidence from the bond and stock markets, Working Paper.

Defusco, R.A., R.R. Johnson, and T.S. Zorn, 1990, The effect of executive stock option 
plans on stockholders and bondholders, Journal of Finance 45, 617-627.

Fama, E. F., and K. R. French, 1997, Industry costs of equity, Journal of Financial Economics 43, 153-193.

Gertner, R.H., D.S. Scharfstein and J.C. Stein, 1994, Internal versus external capital markets, Quarterly Journal of Economics 109, 1211-1230.

Gompers, Paul, Joy Ishii, and Andrew Metrick, 2003, Corporate governance and equity prices, Quarterly Journal of Economics 118, 107-155.

Guay, W. R., 1999, The sensitivity of CEO wealth to equity risk: an analysis of the magnitude and determinants, Journal of Financial Economics 53, 43-71.

Hall, B., and J. Liebman, 1998, Are CEOs really paid like bureaucrats?, Quarterly Journal of Economics 113, 653-691.

Haugen, R., and L. Senbet, 1981, Resolving the agency problems of external capital through options, Journal of Finance 36, 629-648.

Hartzell, J. C., and L. T. Starks, 2003, Institutional investors and executive compensation, Journal of Finance 58, 2351-2374.

Houston, J., C. James, and D. Marcus, 1997, Capital market frictions and the role of internal capital markets in banking Journal of Financial Economics 46, 135-164.

Jegadeesh, N., and S. Titman, 1993, Returns to buying winners and selling losers: implications for stock market efficiency, Journal of Finance 48, 65-91.

Jensen, Michael C., and William H. Meckling, 1976, Theory of the firm: managerial behavior, agency costs and ownership structure, Journal of Financial Economics 3, 305-360.

Jin, L., 2002, CEO compensation, diversification, and incentives, Journal of Financial Economics 66, 29-63.

Kaplan, S. N., and L. Zingales, 1997, Do investment-cash flow sensitivities provide useful measures of financing constraints?, Quarterly Journal of Economics 112, 169-215.

Kayhan, A., and S. Titman, 2003, Firms' histories and their capital structures, Working Paper, University of Texas.

Khanna, Naveen, and Sheri Tice, 2001, The Bright Side of Internal Capital Markets, Journal of Finance 56, 1489-1528.

Lamont, Owen, 1997, Cash flow and investment: Evidence from internal capital markets, Journal of Finance 52, 83-109.

Lamont, O., and C. Polk, 2002, Does diversification destroy value? Evidence from industry shocks, Journal of Financial Economics 63, 51-77.

Lang, Larry and Rene M. Stulz, 1994, Tobin's q, corporate diversification, and firm performance, Journal of Political Economy 102, 1248-1280.

Maksimovic, V., and G.M. Phillips, 2002, Do conglomerate firms allocate resources inefficiently across industries? Theory and evidence, Journal of Finance 57, 721- 
767.

Matsusaka, J., and V. Nanda, 2002, Internal capital markets and corporate refocusing, Journal of Financial Intermediation 11, 176-216.

Meyer, M., P. Milgrom and J. Roberts, 1992, Organizational prospects, influence costs, and ownership changes, Journal of Economics and Management Strategy 1, 9-35.

Milgrom, P., 1988, Employment contracts, influence activities, and efficient organization design, Journal of Political Economy 96, 42-60.

Milgrom, P. and J. Roberts, 1988, An economic approach to influence activities in organizations, American Journal of Sociology 94, 154-179.

Murphy, Kevin, 1999. Executive compensation, in Handbook of Labor Economics, Ashenfelter, O., and Card, D. (editors), Volume 3, North Holland.

Paul, Jonathan, 1992, On the efficiency of stock-based compensation, Review of Financial Studies 5, 471-502.

Rajan, R., H. Servaes, and L. Zingales, 2000, The cost of diversity: The diversification discount and inefficient investment, Journal of Finance 55, 35-80.

Rose, N. L., and A. Shepard, 1997, Firm diversification and CEO compensation: managerial ability or executive entrenchment?, Rand Journal of Economics 28, 489-514.

Rosen, S., 1992, Contracts and the market for executives, in Contract Economics, Wein, L., and Wijkander, H., (editors), Blackwell Publishers.

Ross, S., 2003, Compensation, incentives, and the duality of risk aversion and riskiness, Journal of finance 59, 207-225.

Scharfstein, D. S., 1998, The dark side of internal capital markets II: evidence from diversified conglomerates, NBER working paper 6352.

Scharfstein, David S., and Jeremy C. Stein, 2000, The dark side of internal capital markets: divisional rent-seeking and inefficient investment, Journal of Finance 55, 2537-2564.

Servaes, H., 1996, The value of diversification during the conglomerate merger wave, Journal of Finance 51, 1201-1225.

Shin, Hyun-Han, and René M. Stulz, 1998, Are internal capital markets efficient?, Quarterly Journal of Economics 113, 531-552.

Skinner, D., 1993, The investment opportunity set and accounting procedure choice: preliminary evidence, Journal of Accounting and Economics 16, 407-445.

Smith, C., and R. Stulz, 1985, the determinants of firm's hedging policies, Journal of Financial and Quantitative Analysis 20, 391-405.

Smith, Clifford, and Ross Watts, 1992, The investment opportunity set and corporate financing, dividend, and financing policies, Journal of Financial Economics 32, 262-292. 
Stein, Jeremy C., 2003, Agency, information and corporate investment, in Handbook of the Economics of Finance, Constantinides, G., Harris, M., and Stulz, R., (editors), Volume 1A, Elsevier Science B.V..

Whited, T.M., 2001, Is it inefficient investment that causes the diversification discount?, Journal of Finance 56, 1667-1691.

Wulf, J., 1999, Influence and inefficiency in the internal capital market: theory and evidence, Working Paper, University of Pennsylvania.

Wulf, J., 2002, Internal capital markets and firm-level compensation incentives for division managers, Journal of Labor Economics 20, 5219-5262.

Xue, Y., 2004, Make or buy new technology: a CEO compensation contract's role in a firm's route to innovation, Working Paper.

Yermack, D., 1995, Do corporations award CEO stock-options effectively, Journal of Financial Economics 39, 237-269.

Yermack, D., 1996, Higher market valuation of companies with a small board of directors, Journal of Financial Economics 40, 185-211. 


\section{Vita}

Li Yong was born in Shanghai, China on November 26, 1977, the daughter of Qingsheng Yong and Huijun Zheng. In May 2000, she received the degree of Bachelor of Arts from Agnes Scott College in Atlanta, Georgia. In August 2000 she entered the Ph.D. program in Finance at The University of Texas at Austin. In July 2005, she became an Assistant Professor of Finance at The University of Texas at Arlington.

Permanent Address: 8216 Longfellow Lane, Fort Worth, Texas 76120

This dissertation was typed by the author. 